\title{
WestVirginiaUniversity
}

THE RESEARCH REPOSITORY @ WVU

Graduate Theses, Dissertations, and Problem Reports

2010

\section{A field evaluation of dust palliatives in West Virginia}

Kevin A. Butler

West Virginia University

Follow this and additional works at: https://researchrepository.wvu.edu/etd

\section{Recommended Citation}

Butler, Kevin A., "A field evaluation of dust palliatives in West Virginia" (2010). Graduate Theses,

Dissertations, and Problem Reports. 2170.

https://researchrepository.wvu.edu/etd/2170

This Thesis is protected by copyright and/or related rights. It has been brought to you by the The Research Repository @ WVU with permission from the rights-holder(s). You are free to use this Thesis in any way that is permitted by the copyright and related rights legislation that applies to your use. For other uses you must obtain permission from the rights-holder(s) directly, unless additional rights are indicated by a Creative Commons license in the record and/ or on the work itself. This Thesis has been accepted for inclusion in WVU Graduate Theses, Dissertations, and Problem Reports collection by an authorized administrator of The Research Repository @ WVU. For more information, please contact researchrepository@mail.wvu.edu. 


\title{
A FIELD EVALUATION OF DUST PALLIATIVES IN WEST VIRGINIA
}

\author{
Kevin A. Butler \\ Thesis submitted to the \\ College of Engineering and Mineral Resources \\ at West Virginia University \\ in partial fulfillment of the requirements for the degree of \\ Master of Science \\ in \\ Civil Engineering
}

John Zaniewski, Ph.D., Chair

Ronald Eck, Ph.D.

Andrew Morgan, M.S.C.E.

Department of Civil and Environmental Engineering

Morgantown, West Virginia

2010

Keywords: Dust control; suppressants; abatement; palliatives; gravel road; unpaved road 


\title{
ABSTRACT \\ A FIELD EVALUATION OF DUST PALLIATIVES IN WEST VIRGINIA
}

\author{
Kevin A. Butler
}

It is estimated that a vehicle making a single pass on one mile of untreated, unpaved road every day can generate one ton of dust per year. This dust constitutes fine materials which act as a binder to the larger coarse aggregates within surface gravel. As these fines are removed, the surface deteriorates and expensive aggregate ends up along the roadside in ditches and culverts. The surface continually deteriorates until the road must be reconstructed. Furthermore, airborne dust presents serious safety concerns to traveling motorists and health concerns associated with respiratory illnesses. At the West Virginia Division of Highway's current funding levels it is anticipated that less hot-mix asphalt will be used to pave roadways for the purpose of dust control. If the road is treated with a chemical dust suppressant, however, it can retain a percentage of fines that would otherwise be expelled as dust.

The purpose of this thesis was to evaluate the effectiveness of five commercially available chemical dust palliatives for use on public gravel secondary roads in West Virginia. Dust control products included in this study are a petroleum emulsion with polymer, synthetic organic fluid, calcium chloride, bituminous resin pitch, and lignin sulfonate. Three methods of field testing were used which included a mobile dust sampling device, soil silt fractions, and moisture analyses. Results of field testing indicated that calcium chloride was the most costeffective material for providing dust control throughout the evaluation period. All but one product provided some measurable degree of dust control at the end of the three-month evaluation period when compared to the four untreated control sections. 


\section{ACKNOWLEDGEMENTS}

I would first like to thank my advisor, Dr. John Zaniewski, for his continued support and guidance throughout the development of this thesis. Additional thanks goes to my advisory committee, Dr. Ronald Eck and Andrew Morgan, for their assistance throughout this process. I would also like to thank the WVDOH District Three Engineers for initiating this project, as well as Donald Williams for his oversight and involvement. I also extend my sincere gratitude to each of the dust control product distributors for providing their products and services. Finally, I want to thank my family and friends for their patience, uplifting support, and encouragement throughout this experience; without them it would not have been possible. 


\section{TABLE OF CONTENTS}

Chapter 1 Introduction 1

1.1 Background 1

1.2 Problem Statement 2

1.3 Objectives 2

1.4 Scope and Limitations 3

1.5 Organization of Thesis 3

Chapter 2 Literature Review $\quad 5$

2.1 Introduction $\quad 5$

2.2 Geotechnical Properties of Soils 5

2.2.1 Soil Particle Size Limits 5

2.2.2 Grain-size Distribution 6

2.3 Properties of Aggregates in Gravel Roads 7

2.3.1 Layers of a Gravel Road 7

2.3.2 Gradation $\quad 8$

$\begin{array}{ll}2.3 .3 \text { Plasticity } & 10\end{array}$

2.4 Dust Characterization 11

2.5 Sources of Dust Emission 12

2.6 Fugitive Dust- Public Safety and Health 16

2.7 Commercially Available Dust Palliatives 18

2.7.1 Water 19

2.7.2 Water Absorbing Products 19

2.7.3 Organic Petroleum Products 20 
2.7.4 Organic Nonpetroleum Products 21

2.7.5 Electrochemical Products 21

2.7.6 Synthetic Polymer Emulsions 22

$\begin{array}{ll}\text { 2.7.7 Clay Additives } & 22\end{array}$

2.8 Previous Studies on Chemical Dust Palliatives 23

2.9 Summary of Dust Control Product Research 32

Chapter 3 Dust Palliative Product Selections 35

3.1 Criteria for Product Selection 35

3.1.1 Manufacturers' Product Recommendation 35

3.1.2 Expected Construction Cost 36

3.1.3 Availability 36

3.1.4 Suggested Number of Applications 36

3.1.5 Application Rate 37

3.1.6 Application Method 37

3.1.7 Dilution 37

3.1.8 Curing Time $\quad 37$

3.1.9 Expected Longevity 38

3.1.10 Reported Limitations 38

3.2 Selected Products $\quad 40$

Chapter 4 Demonstration Sites $\quad 41$

4.1 Criteria for Test Route Selection 41

4.1.1 Potential Test Routes 41

4.1.2 Route Length $\quad 42$

4.1.3 Relative Amounts of Shaded Areas 43

4.1.4 Roadway Linearity 43

4.1.5 Surface Gravel Condition and Uniformity 43

4.1.6 Surrounding Agricultural Land Use $\quad 44$ 
4.1.7 Personnel Safety 44

4.2 Route Selected for Experimental Evaluation 47

4.2.1 Section Length $\quad 47$

4.2.2 Surface Gravel Condition and Uniformity 47

4.2.3 Relative Amounts of Shaded Areas 48

4.2.4 Roadway Linearity $\quad 48$

4.2.5 Surrounding Agricultural Land Use $\quad 51$

4.2.6 Personnel Safety $\quad 51$

4.2.7 Survey Results of Citizens Living Adjacent to Test Route 51

4.3 Configuration of Test Sections $\quad 51$

4.4 Application of Treatments

Chapter 5 Measurement and Monitoring $\quad 57$

$\begin{array}{ll}5.1 \text { Dust Collection } & 57\end{array}$

5.2 Sampling Surface/Bulk Dust Loading 62

$\begin{array}{ll}\text { 5.3 Data Collection Schedule } & 63\end{array}$

5.4 Weather Measurements $\quad 64$

Chapter 6 Results and Analysis 66

$\begin{array}{ll}\text { 6.1 Dust Measurement Data } & 68\end{array}$

6.1.1 Day-8 Analysis $\quad 68$

6.1.2 Day-15 Analysis $\quad 69$

6.1.3 Day-28 Analysis $\quad 71$

6.1.4 Day-61 Analysis $\quad 72$

6.1.5 Day-103 Analysis $\quad 73$

6.1.6 Comparison of Dust Measurements across Time 74

$\begin{array}{ll}\text { 6.2 Soil Silt Fractions } & 78\end{array}$ 
$\begin{array}{ll}\text { 6.2.1 Day-28 Analysis } & 78\end{array}$

$\begin{array}{ll}\text { 6.2.2 Day-61 Analysis } & 79\end{array}$

6.2.3 Day-103 Analysis $\quad 80$

6.2.4 Comparison of Soil Silt Fractions across Time 82

6.3 Soil Moisture Contents $\quad 85$

6.3.1 Day-7 Analysis $\quad 85$

6.3.2 Day-28 Analysis $\quad 86$

6.3.3 Day-61 Analysis $\quad 87$

6.3.4 Day-103 Analysis $\quad 88$

6.3.5 Comparison of Soil Moisture Content Data across Time 90

6.4 Estimated $\mathrm{PM}_{10}$ Emissions Using EPA AP-42 Equation 93

6.4.1 Day-8 Analysis 93

6.4.2 Day-28 Analysis $\quad 94$

6.4.3 Day-61 Analysis 95

6.4.4 Day-103 Analysis 96

6.4.5 Comparison of Estimated $\mathrm{PM}_{10}$ Emissions across Time 97

Chapter 7 Conclusions and Recommendations 103

$\begin{array}{ll}\text { 7.1 Conclusions } & 103\end{array}$

7.2 Recommendations for Further Study 106

$\begin{array}{ll}\text { References } & 107\end{array}$

Appendix A Gravel Road Inventory Data Collection Form for Oak Grove Road 110

Appendix B Gravel Road Condition Surveys for Oak Grove Road 112

Appendix C Activity Log During Product Evaluation Period 116

Appendix D Weather Observations During Product Evaluation Period 120

$\begin{array}{ll}\text { Appendix E Dust Measurement Data } & 125\end{array}$ 


\section{LIST OF FIGURES}

Figure 2.1 National PM 10 Emissions by Source Sector in 2005

Figure 4.1 Gravel Road Inventory Data Collection Form 45

Figure 4.2 Gravel Road Condition Survey 46

Figure 4.3 Aggregate Gradation Curves for Surface Gravel on Oak Grove Road 49

Figure 4.4 Rutting and Potholes on Oak Grove Road Prior to Road Maintenance 50

Figure 4.5 Potholes on Oak Grove Road Prior to Road Maintenance 50

Figure 5.1 Schematic of Colorado State University Dustometer 58

Figure 5.2 Rear View of Dust Collector Mounted to Bumper of Test Vehicle 60

Figure 5.3 Opening of Filter Box Facing the Rear Wheel of Test Vehicle 60

Figure 5.4 Cross Sectional View of Dust Collector 61

Figure 5.5 Collection of a Surface/Bulk Dust Loading Sample 63

Figure 5.6 Weather Observations throughout Observation Period 65

Figure 6.1 Summary of Fit for Day-8 Dust Collection Data 68

Figure 6.2 ANOVA Table for Day-8 Dust Collection Data 68

Figure 6.3 Tukey-Kramer Connecting Letter Report for Day-8 Dust Collection Data 69

Figure 6.4 Summary of Fit for Day-15 Dust Collection Data 70

Figure 6.5 ANOVA Table for Day-15 Dust Collection Data 70

Figure 6.6 Tukey-Kramer Connecting Letter Report for Day-15 Dust Collection Data 70

Figure 6.7 Summary of Fit for Day-28 Dust Collection Data 71 
Figure 6.8 ANOVA Table for Day-28 Dust Collection Data

Figure 6.9 Tukey-Kramer Connecting Letter Report for Day-28 Dust Collection Data 72

Figure 6.10 Summary of Fit for Day-61 Dust Collection Data

Figure 6.11 ANOVA Table for Day-61 Dust Collection Data

Figure 6.12 Tukey-Kramer Connecting Letter Report for Day-61 Dust Collection Data 73

Figure 6.13 Summary of Fit for Day-103 Dust Collection Data

Figure 6.14 ANOVA Table for Day-103 Dust Collection Data

Figure 6.15 Tukey-Kramer Connecting Letter Report for Day-103 Dust Collection Data74

Figure 6.16 Trends of Dust Measurements across Time

Figure 6.17 Bar Chart Summarizing Dust Measurements across Time

Figure 6.18 Summary of Fit for Day-28 Soil Silt Fractions Data

Figure 6.19 ANOVA Table for Day-28 Soil Silt Fractions Data

Figure 6.20 Tukey-Kramer Connecting Letter Report for Day-28 Soil Silt Fractions Data79

Figure 6.21 Summary of Fit for Day-61 Soil Silt Fractions Data

Figure 6.22 ANOVA Table for Day-61 Soil Silt Fractions Data

Figure 6.23 Tukey-Kramer Connecting Letter Report for Day-61 Soil Silt Fractions Data80

Figure 6.24 Summary of Fit for Day-103 Soil Silt Fractions Data

Figure 6.25 ANOVA Table for Day-103 Soil Silt Fractions Data

Figure 6.26 Tukey-Kramer Connecting Letter Report for Day-103 Soil Silt Fractions

Data

Figure 6.27 Trends of Soil Silt Fractions across Time

Figure 6.28 Bar Chart Summarizing Soil Silt Load Data across Time

Figure 6.29 Summary of Fit for Day-8 Soil Moisture Content Data

Figure 6.30 ANOVA Table for Day-8 Soil Moisture Content Data 
Figure 6.31 Tukey-Kramer Connecting Letter Report for Day-8 Soil Moisture Content $\begin{array}{ll}\text { Data } & 86\end{array}$

Figure 6.32 Summary of Fit for Day-28 Soil Moisture Content Data 87

Figure 6.33 ANOVA Table for Day-28 Soil Moisture Content Data 87

Figure 6.34 Tukey-Kramer Connecting Letter Report for Day-28 Soil Moisture Content

Data

Figure 6.35 Summary of Fit for Day-61 Soil Moisture Content Data 88

Figure 6.36 ANOVA Table for Day-61 Soil Moisture Content Data 88

Figure 6.37 Tukey-Kramer Connecting Letter Report for Day-61 Soil Moisture Content Data

Figure 6.38 Summary of Fit for Day-103 Soil Moisture Content Data 89

Figure 6.39 ANOVA Table for Day-103 Soil Moisture Content Data 89

Figure 6.40 Tukey-Kramer Connecting Letter Report for Day-103 Soil Moisture Content Data

Figure 6.41 Trends of Soil Moisture Contents across Time 91

Figure 6.42 Bar Chart Summarizing Soil Moisture Contents across Time 92

Figure 6.43 Summary of Fit for Day-8 Estimated $\mathrm{PM}_{10}$ Emissions 93

Figure 6.44 ANOVA Table for Day-8 Estimated PM $_{10}$ Emissions 94

Figure 6.45 Tukey-Kramer Connecting Letter Report for Day-8 Estimated PM $_{10}$ Emissions

Figure 6.46 Summary of Fit for Day-28 Estimated PM 10 Emissions $_{95}$

Figure 6.47 ANOVA Table for Day-28 Estimated PM Amissions $_{10}$ Em

Figure 6.48 Summary of Fit for Day-61 Estimated PM 10 Emissions $_{95}$

Figure 6.49 ANOVA Table for Day-61 Estimated PM Amissions $_{10}$ Em

Figure 6.50 Tukey-Kramer Connecting Letter Report for Day-61 Estimated $\mathrm{PM}_{10}$ $\begin{array}{ll}\text { Emissions } & 96\end{array}$ 
Figure 6.51 Summary of Fit for Day-103 Estimated PM 10 Emissions 97

Figure 6.52 ANOVA Table for Day-103 Estimated PM I0 Emissions $_{97}$

Figure 6.53 Tukey-Kramer Connecting Letter Report for Day-103 Estimated $\mathrm{PM}_{10}$

$\begin{array}{ll}\text { Emissions } & 97\end{array}$

Figure 6.54 Trends of Estimated $\mathrm{PM}_{10}$ Emissions across Time 99

Figure 6.55 Bar Chart Summarizing Estimated PM $_{10}$ Emissions across Time 100

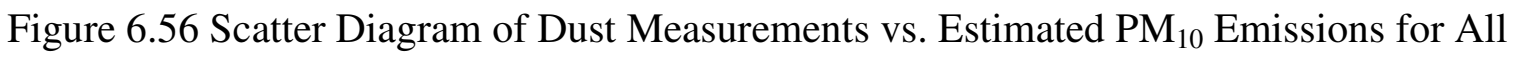

$\begin{array}{ll}\text { Sections } & 101\end{array}$

Figure 6.57 Scatter Diagram of Dust Measurements vs. Estimated $\mathrm{PM}_{10}$ Emissions for Untreated Control Sections

102

Figure A.1 Gravel Road Inventory Data Collection Form for Oak Grove Road 111

Figure B.1 Gravel Road Condition Survey of Oak Grove Road at MP 0.80

Figure B.2 Gravel Road Condition Survey of Oak Grove Road at MP 1.60 114

Figure B.3 Gravel Road Condition Survey of Oak Grove Road at MP 2.55 115

\section{LIST OF TABLES}

Table 2.1 Particle Size Classifications (Das, 2007) 6

Table 2.2 West Virginia Division of Highways Aggregate Gradation Specifications 9

Table 2.3 West Virginia Division of Highways Aggregate Quality Requirements 11

Table 2.4 Range of Source Conditions for Equations 2.1 and 2.2 (U.S. EPA, 1995) 15

Table 2.5 Constants for Equations 2.1 and 2.2 (U.S. EPA, 1995) 15

Table 2.6 Emission Factor for 1980's Vehicle Fleet Exhaust, Brake Wear, and Tire Wear (U.S. EPA, 1995) 15

Table 2.7 Summary of Previous Studies on Chemical Dust Palliatives 33

Table 3.1 List of Potential Dust Suppressants 39 
Table 4.1 Potential Gravel Road Test Routes $\quad 42$

Table 4.2 Arrangement of Sections on Test Route 52

Table 4.3 Number of Passes per Product Application and Observations during Applications $\quad 56$

Table 5.1 Number of Consecutive Dry Days before Each Day of Data Collection $\quad 64$

Table 6.1 Summary of Dust Measurements, Soil Silt Fractions, Soil Moisture Contents, and $\mathrm{PM}_{10}$ Emissions Estimates $\quad 67$

Table 7.1 Estimated Costs of Products 104

Table E.1 Day-8 Dust Measurement Data 126

Table E.2 Day-15 Dust Measurement Data 126

Table E.3 Day-28 Dust Measurement Data $\quad 127$

Table E.4 Day-61 Dust Measurement Data 127

Table E.5 Day-103 Dust Measurement Data 128

Table F.1 Day-28 Silt Load Fractions $\quad 130$

Table F.2 Day-61 Silt Load Fractions $\quad 130$

Table F.3 Day-103 Silt Load Fractions 131

Table G.1 Day-8 Soil Moisture Contents 133

Table G.2 Day-28 Soil Moisture Contents 133

Table G.3 Day-61 Soil Moisture Contents 134

Table G.4 Day-103 Soil Moisture Contents 134

Table H.1 Day-8 PM PM Emissions Estimates $_{136}$

Table H.2 Day-28 PM PM $_{10}$ Emissions Estimates 136

Table H.3 Day-61 PM PM Emissions Estimates $_{137}$

Table F.4 Day-103 PM 10 $_{10}$ Emissions Estimates 137 


\section{CHAPTER 1 INTRODUCTION}

\subsection{BACKGROUND}

Nationally 3.1 million miles of public roadway are classified as rural. Approximately 50 percent of rural roads are unpaved, accounting for 1.6 million miles of public roadway. City and county governments are responsible for funding and maintaining 95 percent of rural unpaved roads and 55 percent of rural paved roads. (FHWA, 2001a)

The West Virginia Division of Highways (WVDOH) has approximately 14,000 miles of aggregate surfaced roadway. Additionally, some roads that were previously hotmix asphalt (HMA) or surface treated have been allowed to deteriorate into aggregate surfaces, thereby increasing the amount of aggregate surface roadway. Dust that is expelled from these roads is a nuisance that road officials would like to minimize for citizens. Air borne dust generates safety concerns such as reduced visibility, health and environmental concerns, and indicates surface deterioration. At the WVDOH's current funding levels it is anticipated that less HMA will be used to pave sections for the purpose of dust control.

There are a variety of products commercially available for dust control. These products work by: 1.) attracting moisture, 2.) binding dust particles together, 3.) sealing the surface, or 4.) some combination of these effects. Chloride salts are moisture attractants, which work by drawing moisture out of the air during periods of high humidity, particularly at night. They also reduce the evaporation rate of water during hot-dry periods. Moisture in the gravel road surface tends to hold the dust on the road 
surface, although there is no physical bonding. Physical binders for dust control involve the application of organic or synthetic compounds that bind the dust particles together and attach them to the larger aggregate. Some of these binding materials produce a surface similar to an asphalt emulsions treatment, but at a lower cost. Surface sealants work by either adhering or agglomerating the surface particles together and often form a semi-rigid film on the road surface.

\subsection{PROBLEM STATEMENT}

Several studies have been performed on the relative field performances of various chemical dust control products. However, questions remain within the search for an economical yet durable dust palliative. What are the most cost-effective materials available which could be integrated into the WVDOH maintenance program? What testing procedures should be followed to determine the performances of various products? This experiment will identify and compare, through quantitative field measurements, commercially available dust palliatives which are relevant to this geographic, geologic, and climatic region.

\subsection{OBJECTIVES}

The objectives of this fugitive dust control effectiveness study are as follows:

- To evaluate current WVDOH practices and procedures for dust abatement on unpaved roads.

- To review published studies of dust suppression, and based on this literature, select dust suppressant products and application practices which 
have potential to reduce fugitive dust emissions from public unpaved roads in West Virginia.

- To select data analysis and field measurement techniques most suitable for the quantification of suppressant effectiveness.

- To evaluate the costs and practicality of applying these dust control products to reduce fugitive dust emissions in West Virginia.

\subsection{SCOPE AND LIMITATIONS}

Five commercially available dust control products were applied to a test route near Parkersburg, WV receiving approximately 30 ADT. The performance of these products was compared against that of four untreated control sections. All products were topically applied to the roadway during June 28-30, 2010 and a 103-day evaluation period followed. Only single applications of the dust palliatives were applied.

Measurements were obtained at $8,15,28,61$, and 103 days following product applications using three different evaluation procedures, including moisture analyses, silt load sampling, and a mobile dust collection device. The results obtained through this experiment are only valid for similar traffic conditions, geology, climate, topography, drainage conditions, and products used herein.

\subsection{ORGANIZATION OF THESIS}

This thesis contains seven chapters. Chapter 1 is the introduction to the thesis. Chapter 2 contains the literature review in regards to the geotechnical properties of soils and gravel roads; the sources, characterization, and safety concerns of airborne dust; the commercially available chemical dust palliatives; and previous studies on dust palliatives. 
Chapter 3 presents the criteria for selecting dust palliatives and identifies the products chosen for use in this experiment. Chapter 4 explains the criteria used for selection of a demonstration site and identifies the test route used. The measuring and monitoring techniques for evaluation of products is demonstrated in Chapter 5. Chapter 6 contains the results and analysis of field testing. Finally, conclusions and recommendations are presented in Chapter 7. Appendix A contains the Gravel Road Inventory Data Collection Form; Appendix B contains the Gravel Road Condition Surveys used on the selected test route; Appendix C includes a log of activities; Appendix D lists the weather observations throughout the evaluation period; Appendices $\mathrm{E}$ through $\mathrm{G}$ contains raw data obtained for dust measurements, soil silt fractions, and moisture analyses; and Appendix H contains $\mathrm{PM}_{10}$ emission estimates calculated with the EPA AP-42 equation. 


\section{CHAPTER 2 LITERATURE REVIEW}

\subsection{INTRODUCTION}

This review provides an introduction to desirable geotechnical properties of soils and aggregates on gravel roads and current West Virginia gravel road specifications. Additionally, an explanation is provided as to how the EPA characterizes, classifies, and estimates particulate emissions. Also public safety and health concerns associated with particulate emissions on gravel roads are reviewed. Finally, since numerous chemical dust control products exist throughout the Unites States, this review summarizes recent national and international studies on the relative performance of various chemical dust control products.

\subsection{GEOTECHNICAL PROPERTIES OF SOILS}

\subsubsection{Soil Particle Size Limits}

Generally, soils are classified as gravel, sand, silt, or clay, depending on their respective particle sizes. Many organizations have developed classification systems based on soil particle size. Table 2.1 presents soil particle size classifications developed by the American Association of State Highway and Transportation Officials (AASHTO), the U.S. Army Corps of Engineers and U.S. Bureau of Reclamation (Unified Soil Classification System), and the U.S. Department of Agriculture. (Das, 2006) 
Table 2.1 Particle Size Classifications (Das, 2007)

\begin{tabular}{lcccc}
\hline \multicolumn{1}{c}{ Organization } & \multicolumn{2}{c}{ Grain Size $(\mathbf{m m})$} & Clay \\
\cline { 2 - 5 } & $\begin{array}{c}\text { Gravel or } \\
\text { Stone }\end{array}$ & Sand & Silt & $<0.002$ \\
\hline \hline AASHTO & 75 to 2 & 2 to 0.075 & 0.075 to 0.002 & $<0.002$ \\
$\begin{array}{l}\text { Unified Soil } \\
\text { Classification Method } \\
\text { (U.S. Army Corps of }\end{array}$ & 76.2 to 4.75 & 4.75 to 0.075 & 0.075 to 0.002 & \\
$\begin{array}{l}\text { Engineers \& U.S. } \\
\text { Bureau of Reclamation) }\end{array}$ & & & & $<0.002$ \\
USDA & $>2$ & 2 to 0.05 & 0.05 to 0.002 & \\
\hline
\end{tabular}

Cobbles and boulders are very large (particle sizes $>75 \mathrm{~mm}$ ) and should not be used in the base and surface of roads. They are, however, very useful for erosion control, scour protection and filling gabions (Freeman and Fischenich, 2000). Coarse-grained soils consist of gravels and sands. Gravel particles are relatively large and have high strength. Due to their importance in providing strength, the mixture of particles used to build roads is referred to as gravel. Sands drain well and are relatively stable. Sands also help to fill the voids between gravel particles. Fines (silts and clays) are the smallest size particles. Silt is microscopic sedimentary material which has very little cohesion.

Therefore, silts compact poorly and provide little or no dry strength. Clay consists of microscopic and submicroscopic particles which have very high cohesion. Clays are impermeable and have low strength when saturated. The primary purpose of fines in gravels is to help bind together surface materials exposed to traffic.

\subsubsection{Grain-size Distribution}

Soil classification is based on grain size distribution. The grain-size distribution of coarse-grained soil (particle sizes $>0.075 \mathrm{~mm}$ in diameter) is typically determined by 
a sieve analysis, ASTM C136. Conversely, for a fine-grained soil (particle sizes $<0.075$ $\mathrm{mm}$ in diameter), the grain-size distribution can be obtained by a hydrometer analysis, ASTM D422. (Das, 2007)

\subsection{PROPERTIES OF AGGREGATES IN GRAVEL ROADS}

Good sources of gravel vary depending on the region and local sources of aggregate available. Natural sources of aggregate include: quarry aggregate such as limestone, quartzite, and granite; river run gravels which include a mixture of stone and sand; and glacial deposits of stone, sand, silt and clay (Skorseth and Selim, 2000). Gravel generally comes from pits and river deposits, whereas crushed stones, typically, are the result of processing rocks from quarries (Mamlouk and Zaniewski, 2011). Throughout many parts of West Virginia, good quality natural gravel is not available. For this reason, crushed limestone from rock quarries is often used for gravel road construction.

\subsubsection{Layers of a Gravel Road}

Gravel roads generally have two layers: the surface and base. The surface is the top course in a gravel road and is sometime referred to as the wearing course. The surface course acts as a leveling layer to provide a smooth driving surface and forms a crust to shed water. The base layer is the layer immediately beneath the surface course and is typically composed of crushed stone. The base course should consist of very high quality material, especially if the surface course is relatively thin. Sometimes, a subbase below the base course may be provided. A subbase layer helps continue spreading the vehicle loads over the subgrade and aids in drainage (Cornell Local Roads Program, 1996). According to Huang in Pavement Analysis and Design, "The reason that two 
different granular materials are used is for economy. Instead of using the more expensive base course material for the entire layer, local and cheaper materials can be used as a subbase course on top of the subgrade." The subgrade is the native material underlying the roadway.

\subsubsection{Gradation}

Since the construction of a gravel road is essentially the procedure of utilizing the local available materials, wide variation among size grading and the quality of gravel occurs. Generally, good gravel for the base and subbase courses will have a higher percentage of top-sized stone and a low percentage of fine materials. This gradation is necessary for the strength and permeability needed in the base layer. Conversely, the surface gravel should consist of material which will form a crust to keep the material bound together and serve as an impervious barrier (Skorseth and Selim, 2000). Typically, the surface course consists of a blend of stone, sand, and fines (silts and clays). Small sands and fines should be present to fill the voids between the larger aggregates so the mixture may be compacted (Cornell Local Roads Program, 1996). Many states have gradation specifications for surface gravel, base material, and subbase material (if used). WVDOH specifications require that Class 3 aggregate material be used on all shoulders and surface courses (WVDOH, 2000). Table 2.2 provides WVDOH gradation specifications for various classes of aggregates. 
Table 2.2 West Virginia Division of Highways Aggregate Gradation Specifications

\begin{tabular}{|c|c|c|c|c|c|c|c|c|c|}
\hline \multicolumn{10}{|c|}{ Gradation Amounts Finer Than Each Laboratory Sieve (Square Openings), \% By Weight } \\
\hline $\begin{array}{l}\text { Aggr. } \\
\text { Class }\end{array}$ & $8 "(200)$ & $\begin{array}{c}21 / 2^{\prime \prime} \\
(63)\end{array}$ & $\begin{array}{c}2 " \\
(50)\end{array}$ & $\begin{array}{l}11 / 2 " \\
(37.5)\end{array}$ & $\begin{array}{l}3 / 4 " \\
(19)\end{array}$ & $\begin{array}{c}\# 4 \\
(4.75)\end{array}$ & $\begin{array}{c}\# 40 \\
(42.5 \mu \mathrm{m})\end{array}$ & $\begin{array}{c}\# 100 \\
(150 \mu \mathrm{m})\end{array}$ & $\begin{array}{c}\# 200 \\
(75 \mu \mathrm{m})\end{array}$ \\
\hline 1 & & & & 100 & $50-90$ & $20-50$ & $5-20$ & & $0-7$ \\
\hline 2 & & & & 100 & $80-100$ & $35-75$ & $10-30$ & & $0-10$ \\
\hline 3 & & & & 100 & $50-90$ & $20-50$ & $5-20$ & & $4-12$ \\
\hline 4 & & & & 100 & $50-95$ & $20-60$ & $5-35$ & & \\
\hline 5 & & & 100 & & & $30-90$ & & & $0-25$ \\
\hline 6 & & & & 100 & $50-100$ & $25-70$ & $10-45$ & $3-28$ & \\
\hline 7 & $90-100$ & & $0-5$ & \multicolumn{4}{|c|}{$\begin{array}{l}\text { with intermediate sizes between } 6 "(150 \mathrm{~mm}) \text { and } 4 " \\
(100 \mathrm{~mm}) \text { represented }\end{array}$} & & \\
\hline 8 & & & & 100 & $80-100$ & $35-75$ & $10-40$ & & $4-14$ \\
\hline 9 & & 100 & & $80-95$ & $50-70$ & $20-40$ & & & $0-8$ \\
\hline
\end{tabular}




\subsubsection{Plasticity}

Often, an acceptable range for plasticity index is required in state standard specifications for aggregate base course and gravel surfacing. Plasticity Index (PI) is defined as the difference between the liquid limit and the plastic limit of a soil. Liquid and plastic limits are determined using ASTM D4318. Plasticity Index describes the consistency, or cohesive qualities, of soils with varying moisture contents and is also an indication of the amount of shrinkage or swelling that may occur with varying moisture contents (Das, 2007). Soils with a PI value of 10 or less are referred to as "silty" and soils with a PI value of 11 or more are referred to as "clayey."

Surface gravel requires a portion of fine material, usually natural clays, to provide a binding characteristic and thus a smooth driving surface. A deficiency of fine material within a gravel wearing course may lead to raveling during dry periods, excessive permeability, and migration of coarse aggregates to the road edge. It is typically desirable to use aggregates for the base course which have a more open-graded particle size distribution and lower plasticity index to allow for water drainage beneath the surface. Unfortunately, the same gravel is often used for both surface and base courses. Table 2.3 shows WVDOH aggregate quality requirement which limits the plasticity index of the fines to a maximum value of six. 
Table 2.3 West Virginia Division of Highways Aggregate Quality Requirements

\begin{tabular}{|c|c|c|c|c|c|}
\hline $\begin{array}{c}\text { Aggr. } \\
\text { Class }\end{array}$ & $\begin{array}{c}\text { L.A. } \\
\text { Abrasion, } \\
\text { Percent, } \\
\text { Max. }\end{array}$ & $\begin{array}{c}\text { Sodium } \\
\text { Sulphate } \\
\text { Soundness, } \\
\text { Percent Max. }\end{array}$ & $\begin{array}{c}\text { Liquid } \\
\text { Limit, } \\
\text { Max. }\end{array}$ & $\begin{array}{c}\text { Plasticity } \\
\text { Index, } \\
\text { Max. }\end{array}$ & $\begin{array}{c}\text { Deleterious } \\
\text { Material, } \\
\text { Percent, Max. }\end{array}$ \\
\hline 1 & 50 & 12 & 25 & 6 & 5 \\
\hline 2 & 50 & 12 & 25 & 6 & 5 \\
\hline 3 & 50 & 12 & 25 & 6 & 5 \\
\hline 4 & Note 1 & n/a & 25 & 6 & 5 \\
\hline 5 & n/a & n/a & 25 & 6 & 5 \\
\hline 6 & n/a & n/a & 25 & 6 & 5 \\
\hline 7 & n/a & 30 & n/a & n/a & $\begin{array}{c}10 \text { (by visual } \\
\text { observation) }\end{array}$ \\
\hline 8 & 50 & 12 & 25 & 6 & 5 \\
\hline 9 & 50 & 12 & 25 & 6 & 5 \\
\hline
\end{tabular}

\subsection{DUST CHARACTERIZATION}

Dust particle sizes in the atmosphere range from about $10 \mathrm{~nm}$ to $100 \mu \mathrm{m}$. The U.S. Environmental Protection Agency (EPA) classifies particulate matter (PM) in two sizes: fine particles and inhalable coarse particles, with course particles having shorter atmospheric residence times than smaller particles. Fine particles are particles smaller than $2.5 \mu \mathrm{m}$ and are designated as $\mathrm{PM}_{2.5}$. Inhalable coarse particles are particles up to 10 $\mu \mathrm{m}$ in diameter and are designated $\mathrm{PM}_{10}$. The $\mathrm{PM}_{10}$ classification encompasses most types of fugitive dust and is thus the particulate matter particle size fraction of interest. (U.S. EPA, 2010)

The physical characteristics and primary chemical constituents of dust particles are heavily influenced by the source areas and land use (Chow et al., 2003). Chemical 
constituents commonly include oxides of silicon, aluminum, iron, and some calcium compounds (Watson, 1996).

\subsection{SOURCES OF DUST EMISSION}

Particulate matter includes the solid particles and liquid droplets which are projected into the atmosphere by wind, vehicular movement on paved and unpaved roads, construction and demolition of structures, and agricultural activities (Gillies et al., 1999). The principle single source of particulate emissions is, however, unpaved roads (Ferguson et al., 1999). Data from the U.S. Environmental Protection Agency (U.S. EPA) show that road dust contributed approximately 10 million tons of particulate matter air pollution in 2005, equating to roughly half of the nation's total particulate matter air pollution (Figure 2.1). Fugitive dust from roads is a nonpoint source of air pollution, since it does not originate from a specific, or point, source, such as a chimney or stack.

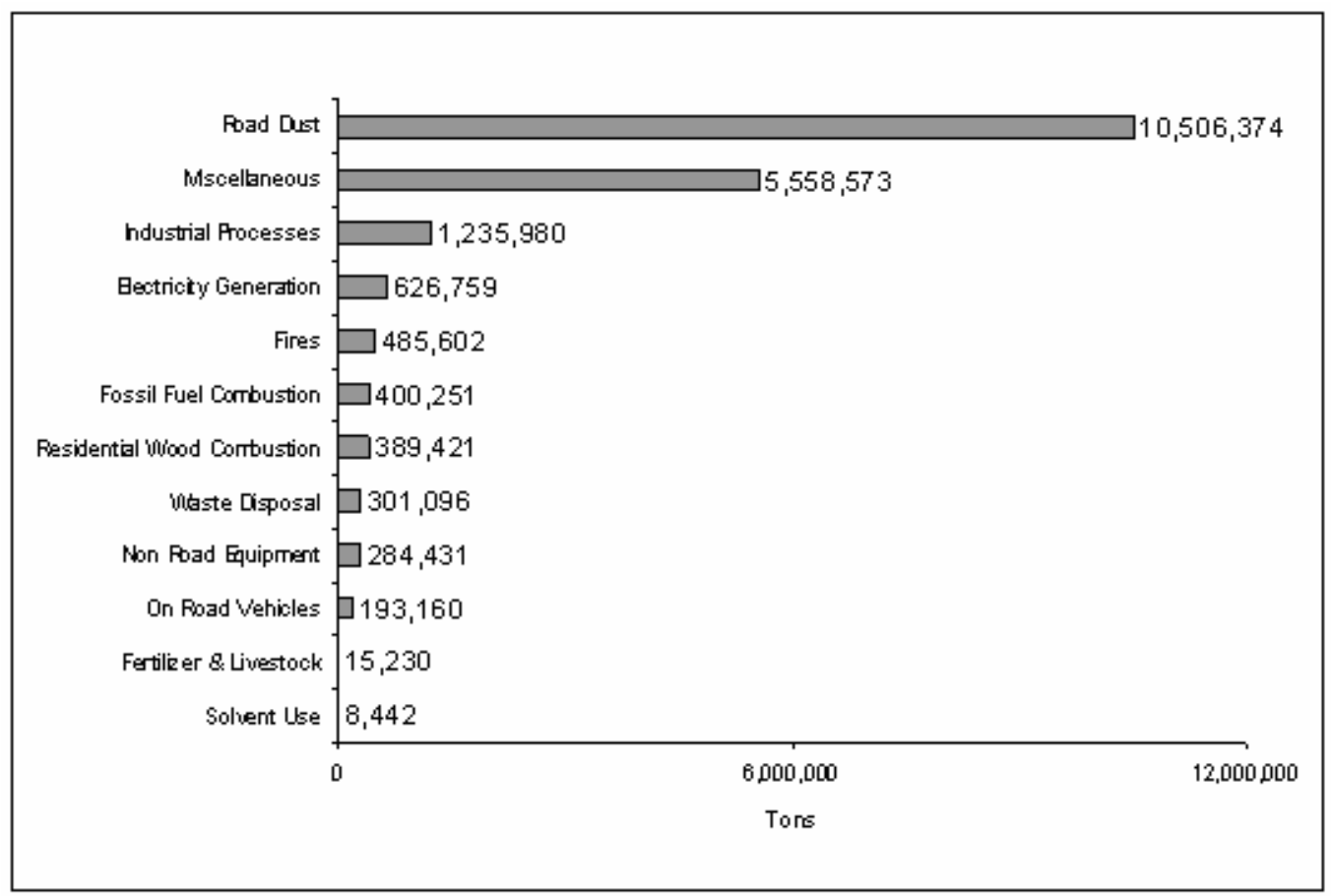

Figure 2.1 National $\mathrm{PM}_{10}$ Emissions by Source Sector in 2005 
When a vehicle travels an unpaved road, the vehicle tires pulverize aggregates at the tire-road surface interface. Particles are then raised and dropped from the rolling wheels, and the road surface is exposed to strong air currents in turbulent shear with the surface (US EPA, 1995). Turbulent wake behind the vehicle acts on the roadway surface after the vehicle has passed. There are a number of factors which influence dust generation, including:

- Number of vehicles

- Mean vehicle speed

- Mean vehicle weight

- Number of wheels per vehicle

- Particle size distribution of surface material

- Restraint of the fine material on surface

- Surface moisture

$\mathrm{PM}_{10}$ emissions from unpaved roads can be estimated using EPA AP-42 empirical equations (U.S. EPA, 1995). The emission factors are the result of stepwise linear regressions from field emission test results of vehicles traveling over unpaved surfaces. A wide range of source conditions was used in the development of these emissions equation, as shown in Table 2.4.

For vehicles traveling on unpaved surfaces at industrial sites, dominated by heavy-duty vehicles, emissions may be estimated by Equation 2.1 .

$$
E=k(s / 12)^{a}(W / 3)^{b}
$$


For vehicles traveling on publicly accessible unpaved roads, dominated by light-duty vehicles, emissions may be estimated using Equation 2.2.

$E=\frac{k(s / 12)^{a}(S / 30)^{d}}{(M / 0.5)^{c}}-C$

Where $\mathrm{a}, \mathrm{b}, \mathrm{c}, \mathrm{d}$, and $\mathrm{k}$ are empirical constants obtained from Table 2.5, and:

$E=$ size-specific emission factor (lb/VMT)

$s=$ surface material silt content $(\%)$

$W=$ mean vehicle weight (tons)

$M=$ surface material moisture content $(\%)$

$S=$ mean vehicle speed $(\mathrm{mph})$

$C=$ emission factor for 1980's vehicle fleet exhaust, brake wear, and tire wear (obtained from Table 2.6)

Data within AP-42 are assigned quality ratings, from "A" to "E" with "A" receiving a score of excellent and "E" receiving a score of poor, to help identify good data, based on both the quality of the test(s) and how well the factor represents the emission source. Factors given higher ratings are based on many unbiased observations or widely accepted test procedures. Conversely, factors receiving low ratings are based on extrapolations from higher-rated factors for similar processes or single observations obtained from questionable methods. 
Table 2.4 Range of Source Conditions for Equations 2.1 and 2.2 (U.S. EPA, 1995)

\begin{tabular}{|c|c|c|c|c|c|c|c|}
\hline \multirow{2}{*}{ Emission Factor } & \multirow{2}{*}{$\begin{array}{c}\text { Surface } \\
\text { Silt } \\
\text { Content } \\
(\%)\end{array}$} & \multicolumn{2}{|c|}{$\begin{array}{c}\text { Mean Vehicle } \\
\text { Weight }\end{array}$} & \multicolumn{2}{|c|}{$\begin{array}{c}\text { Mean Vehicle } \\
\text { Speed }\end{array}$} & \multirow{2}{*}{$\begin{array}{c}\text { Mean } \\
\text { No. of } \\
\text { Wheels }\end{array}$} & \multirow{2}{*}{$\begin{array}{c}\text { Surface } \\
\text { Moisture } \\
\text { Content } \\
(\%)\end{array}$} \\
\hline & & Mg & ton & km/hr & mph & & \\
\hline $\begin{array}{c}\text { Industrial Roads } \\
\text { (Eq. 2.1) }\end{array}$ & $1.8-25.2$ & $1.8-260$ & $2-290$ & $8-69$ & $5-43$ & $4-17$ & $0.03-13$ \\
\hline $\begin{array}{l}\text { Public Roads } \\
\text { (Eq. 2.2) }\end{array}$ & $1.8-35$ & $1.4-2.7$ & $1.5-3$ & $16-88$ & $10-55$ & $4-4.8$ & $0.03-13$ \\
\hline
\end{tabular}

Table 2.5 Constants for Equations 2.1 and 2.2 (U.S. EPA, 1995)

\begin{tabular}{|c|c|c|c|c|c|c|}
\hline \multirow{2}{*}{ Constant } & \multicolumn{3}{|c|}{ Industrial Roads (Eq. 2.1) } & \multicolumn{3}{c|}{ Public Roads (Eq. 2.2) } \\
\cline { 2 - 7 } & PM $_{\mathbf{2 . 5}}$ & $\mathbf{P M}_{\mathbf{1 0}}$ & $\mathbf{P M}_{\mathbf{3 0}}$ & $\mathbf{P M}_{\mathbf{2 . 5}}$ & PM $_{\mathbf{1 0}}$ & PM $_{\mathbf{3 0}}$ \\
\hline $\mathrm{k}$ (lb/VMT) & 0.15 & 1.5 & 4.9 & 0.18 & 1.8 & 6.0 \\
\hline $\mathrm{a}$ & 0.9 & 0.9 & 0.7 & 1 & 1 & 1 \\
\hline $\mathrm{b}$ & 0.45 & 0.45 & 0.45 & - & - & - \\
\hline $\mathrm{c}$ & - & - & - & 0.2 & 0.2 & 0.3 \\
\hline d & - & - & - & 0.5 & 0.5 & 0.3 \\
\hline Quality Rating & $\mathrm{B}$ & $\mathrm{B}$ & $\mathrm{B}$ & $\mathrm{B}$ & $\mathrm{B}$ & $\mathrm{B}$ \\
\hline
\end{tabular}

Table 2.6 Emission Factor for 1980's Vehicle Fleet Exhaust, Brake Wear, and Tire Wear (U.S. EPA, 1995)

\begin{tabular}{|c|c|}
\hline Particle Size Range & $\begin{array}{c}\boldsymbol{C} \text {, Emission } \\
\text { Factor for } \\
\text { Exhaust, Brake } \\
\text { Wear, and Tire } \\
\text { Wear (lb/VMT) }\end{array}$ \\
\hline $\mathrm{PM}_{2.5}$ & 0.00036 \\
\hline $\mathrm{PM}_{10}$ & 0.00047 \\
\hline $\mathrm{PM}_{30}$ & 0.00047 \\
\hline
\end{tabular}

Emissions estimates from Equations 2.1 and 2.2 are adjusted for precipitation.

This estimate simply assumes that average annual emissions are inversely proportional to the number of days with measurable (more than 0.01 in) of rain. Equation 2.3 does not 
account for the quantity of rain during an event, the differences in temporal distributions of the events, or for evaporation from road surface following a rain event.

$$
E_{e x t}=E[(365-P) / 365]
$$

Where,

$E_{\text {ext }}=$ annual size-specific emission factor extrapolated for natural mitigation, $1 \mathrm{~b} / \mathrm{VMT}$

$E=$ emission factor from equation 2.1 or 2.2

$P=$ number of days in a year with at least 0.01 in $(0.254 \mathrm{~mm})$ of precipitation

Dust particles that are suspended in air for a noticeable period of time are generally less than $30 \mu \mathrm{m}$ in diameter and the amount of material in this range is approximately proportional to the wearing course material's erodibility (Thompson and Visser, 2007). Generally, the silt and fine sand content of the surface course is a good indication of its erodibility. However, the fine material cannot be simply removed from the wearing course because a portion of fines is necessary to bind the larger aggregates in the wearing course. Clay content and chemical binders increase soil cohesion, thereby decreasing soil erodibility.

\subsection{FUGITIVE DUST- PUBLIC SAFETY AND HEALTH}

Under dry conditions, fines from the roadway may be projected into the atmosphere by vehicular movement or wind. The adverse affects of deposited and suspended dust include:

- respiratory hazards associated with inhalation,

- increased vehicle and equipment wear,

- loss and degradation of aggregates due to loss of fines, 
- blocking of pavement drainage systems due to dislodged aggregate material,

- potential damage to plants and crops; and

- additional cleaning of homes and vehicles.

According to the U.S EPA, $\mathrm{PM}_{10}$ emissions are among the most harmful of all air pollutants. Upon inhalation, dust particles can circumvent the body's natural respiratory defenses and lodge deep into the lungs. Health problems may include increased number and severity of asthma attacks, bronchitis and other respiratory diseases, and decreased immune response. Although $\mathrm{PM}_{10}$ can affect everyone, certain people are highly affected when exposed to even small amounts of dust and other fine particles. "Sensitive populations" may include individuals with asthma and other respiratory illnesses, those with cardiovascular diseases, the elderly, children, and smokers. Of great concern are recent studies which link fine particle exposure to the premature death of those who fall into the "sensitive population" category.

For the motoring public, dust adversely affects vehicles and equipment in different ways. A vehicle's air filter stops dust and other particles from entering the engine. Driving with a dirty or clogged filter can greatly affect fuel economy and performance of the vehicle. Also, dust that accumulates on moving parts may act as abrasives to significantly decrease the service life of mechanical components.

In severe cases, fugitive dust has been known to interfere with plant growth by clogging pores and reducing light interception thus reducing overall quality and crop yield (Mohamed, \& El Bassouni, 2007). However, there are extreme circumstances in 
which dust provides a key source of nutrients for plants. For example, Saharan dust is thought to be an important plant micronutrient in areas of the Amazon Basin (Swap et al, 1992). Therefore, it has been shown that fugitive dust can both help and hinder plant growth. The effect of dust on plant growth largely depends on the quantity of dust emissions, chemical constituents that comprise the airborne particles, plant species and age, season, and other factors (Cowherd et al, 1990).

\subsection{COMMERCIALLY AVAILABLE DUST PALLIATIVES}

There is an immense variety of dust suppressants on the market today. According to Bolander and Yamada (1999) dust control products can be separated into seven basic categories (listed according to popularity and frequency of past usage): water, water absorbing products, petroleum-based products, organic nonpetroleum-based products, electrochemical products, polymer products, and clay additive products. Typical suppressants in each category include:

- Water

- Water absorbing products

○ Calcium chloride

- Magnesium chloride

- Sodium chloride

- Organic petroleum products

- Asphalt emulsions

○ Bitumen Emulsions

- Modified asphalt emulsions

○ Dust Oils

- Organic nonpetroleum products

○ Lignin sulfonates

- Molasses/sugar beet extract

○ Tall oil emulsions 
○ Vegetable oils

- Electrochemical products

○ Enzymes

○ Ionic products

○ Sulfonated oils

- Synthetic polymer emulsions

○ Polyvinyl acetate

○ Vinyl acrylic

- Clay additives

○ Bentonite

○ Montmorillonite

\subsubsection{Water}

Water is seemingly the cheapest dust palliative. The surface tension of water molecules act to agglomerate the surface particles on the road, thus providing some measure of dust control (Stewart, 2008). A major disadvantage of water is that it readily evaporates, often providing dust control for less than a day. Due to frequent reapplication, water usually becomes the most expensive and labor intensive product to implement in a dust control plan.

\subsubsection{Water Absorbing Products}

Water absorbing products, specifically calcium and magnesium chlorides, are perhaps the most widely used dust palliatives in the United States. Chlorides usually come in the form of either flakes or brine, with the latter being the most abundant. They provide an acceptable combination of application ease, cost, durability, and longevity for most climatic regions. The success of chlorides in controlling dust may be attributed to their hydroscopic nature, in that they absorb moisture from the air as a function of temperature and relative humidity and significantly increase the surface tension of water 
film between particles (Watson, 1996). This interaction helps to slow water evaporation within the soil structure and further compact the roadway as drying progresses. Sodium chloride is typically not recommended for use as a surface application because it requires higher dosages and usually yields poorer field performance compared to calcium and magnesium chlorides.

Application rates for magnesium chloride brine typically range from 0.40 to 0.50 $\mathrm{gal} / \mathrm{yd}^{2}\left(1.81\right.$ to $\left.2.26 \mathrm{~L} / \mathrm{m}^{2}\right)$ to a prewetted surface, assuming approximately 30 percent solids. Application rates for calcium chloride brine typically range from 0.29 to 0.36 $\mathrm{gal} / \mathrm{yd}^{2}\left(1.31\right.$ to $\left.1.63 \mathrm{~L} / \mathrm{m}^{2}\right)$, assuming approximately 38 percent solids, or at 1.5 to 1.9 lb/yd $\mathrm{yd}^{2}\left(0.82\right.$ to $\left.1.03 \mathrm{~kg} / \mathrm{m}^{2}\right)$ with 77 percent pure flakes. (Bolander, 1997) One attractive aspect of using flakes as opposed to brine is that flakes do not run off the surface when applied to a steep grade. Calcium chloride flakes are usually spread onto a damp roadway surface and allowed to dissolve. Brine, however, is applied to the surface using an applicator truck, often making two to three passes, to achieve a desired application rate. With the application of both flakes and brine it is desirable to prewet the road surface, especially in arid climates.

\subsubsection{Organic Petroleum Products}

Asphalt emulsions, polymer modified asphalt emulsions, bitumen emulsions, dust oils, and even recycled waste oils are included in this category. Although the use of any recycled oil for dust suppression is strictly prohibited, a number of asphalt and bitumen emulsions have been approved for use (U.S. EPA, 1992). These products work by binding and/or agglomerating surface particles and serve to waterproof the road. Some products also contain surfactants to assist the penetrating ability of the emulsion. 
Petroleum-based dust suppressants are most often applied topically with an asphalt type distributor truck. If dilution is required, typical dilution rates range between four to six parts water and one part product. Typical application rates range from 0.30 to 0.70 $\mathrm{gal} / \mathrm{yd}^{2}\left(1.4\right.$ to $\left.3.2 \mathrm{~L} / \mathrm{m}^{2}\right)$.

\subsubsection{Organic Nonpetroleum Products}

The most common products within this category are lignin sulfonate derivatives which are water liquor byproducts of sulfite paper-making processes. Its composition depends primarily on the raw materials and chemicals used to extract the wood cellulose fibers (Harkin, 1969). Other products within this category include molasses/sugar beet extracts, tall oil emulsions, and vegetable oils. All organic nonpetroleum products work by either adhering or agglomerating the surface particles together and perform well under arid and semi-arid conditions. Unfortunately, due to long curing times associated with these products, they tend to exhibit failure after heavy rains and gradually leach out. Also, some products may be odorous and/or very sticky upon application.

Most organic nonpetroleum products require one to two treatments per season to achieve an adequate level of dust control. Application rates vary by product, but typically range between 0.25 and $1.0 \mathrm{gal} / \mathrm{yd}^{2}\left(1.1\right.$ to $\left.4.5 \mathrm{~L} / \mathrm{m}^{2}\right)$. Dilution rates vary by product and type of surface application (i.e. topical or windrowed).

\subsubsection{Electrochemical Products}

Products in this category typically include ammonium chloride enzymes, ionic products, and sulfonated oils (Piechota et al, 2004). They work by reacting with claysized particles to alter the mineralogy within the wearing course. Typical dilution rates range from one part product to anywhere from 100 to 600 parts water. These products 
seem to be successful over a wide variety of climatic conditions and are particularly effective on sandy or clayey surfaces (Giummarra, Foley, \& Stephen, 1997). However, field evaluations of products within this category have often yielded sporadic results. Unlike most traditional dust suppressants, electrochemical products have no standard laboratory tests for predicting their performance under field conditions.

\subsubsection{Synthetic Polymer Emulsions}

Generally, products in the synthetic polymer emulsions category include acrylic and acetate polymers or copolymers that are usually manufactured for the paint or adhesive industry. Due to adhesive properties of the polymers, these emulsions work to bind surface particles together and form a semi-rigid film on the road surface. Most products are supplied in concentrated form and require dilution with water prior to application. Polymer emulsions are generally acceptable for use under a range of climatic and soil conditions, however, have been shown to be difficult to maintain as a hard surface (FHWA, 2001b). Unlike some other dust suppressants, most polymer emulsions are considered non-toxic and environmentally sound.

\subsubsection{Clay Additives}

Bentonite and montmorillonite are the two primary types of clay additives which, when mixed in place with an existing road surface, reduce dust formation by agglomerating with fine particles within the wearing course. Results of field trials have generally shown this form of treatment to be cost-effective at reducing dust; however, higher initial costs are associated with clay additives due to increased materials and application costs. Also, roadways containing a high percentage of fine material which 
have been treated with clay additives may become slippery when wet. Typical

application rates are at 1 to $3 \%$ by dry weight. (Bergeson and Brocka, 1996)

\subsection{PREVIOUS STUDIES ON CHEMICAL DUST PALLIATIVES}

Gebhart et al (1996) performed a 100-day evaluation of five dust control products on gravel surfaced roadways at Fort Hood, TX and Fort Sill, OK. Traffic on the roadways consisted primarily of tracked and wheeled vehicles. Dust palliatives evaluated included 38\% calcium chloride, calcium lignosulfonate, two polyvinyl acrylic polymer emulsions, and soybean feedstock processing by-products. Dust suppressants were applied topically, using either a water or asphalt distributor truck capable of metered application, according to manufacturers' recommendations. The Fort Hood and Fort Sill test sections were recently graded 0.3 mile segments. Each product was applied to three replicate sections. There were three untreated control sections at each location.

Field evaluations of relative effectiveness included using oil-coated dust collection pans in conjunction with photographic images. Collection pans were tared prior to field placement and then retrieved at monthly intervals from July to September to weigh. Photographic images of a test vehicle traversing each test section were analyzed using computer image processing techniques to determine changes in the mean levels of obscuration due to dust.

Traffic volume data were obtained throughout the analysis period using magnetic traffic counters. Throughout the study period, traffic volumes at Fort Hood ranged from 61 to 272 ADT, while traffic volumes at Fort Sill ranged from 18 to 200 ADT. 
Performance and cost data indicated calcium chloride provided the greatest amount of control under a wide range of conditions and for periods exceeding 90 days. When exposed to heavy, tracked-vehicle traffic, all treatments except one of the polyvinyl acrylic emulsions remained effective for 30 days following application. Only calcium chloride and calcium lignosulfonate reduced dust levels by at least $50 \%$ up to 60 days after application. Between 60 and 100 days, the effectiveness of all products except calcium chloride approached that of the untreated control sections.

When exposed to lighter tracked and wheeled traffic, calcium chloride, calcium lignosulfonate, and soybean processing by-products showed minimal deterioration after 100 days. Conversely, product deterioration was pronounced for both polyvinyl acrylic polymer emulsions following 100 days.

Sanders, et al (1997) performed a 140 day evaluation of three dust suppressants, including calcium chloride, magnesium chloride, and lignosulfonate. The study was conducted on a public unpaved road in Larimer County, Colorado. The road surface was crushed gravel. Each test section was 1.25 miles long and $33 \mathrm{ft}$ wide. An untreated section was observed as a control. Construction of test sections involved scarifying, grading and smoothing to achieve proper crown and drainage, application of dust suppressants, and compaction. Both calcium chloride and magnesium chloride were applied topically, while a mix-in-place application was used for lignosulfonate. Measurements on the performance of dust suppressants included traffic counts, fugitive dust emissions, and total aggregate loss.

Dust emission data were obtained periodically throughout the evaluation period utilizing a mobile dust sampler created for this experiment, known as the Colorado State 
University Dustometer. The CSU Dustometer was essentially an air filter box, mounted to the bumper of a 3/4 ton pickup truck, with an opening that faced the rear wheel of the vehicle. Dust particles that were projected into the atmosphere by the moving vehicle entered the filter box and settled onto a sheet of glass fiber filter paper. A vacuum was drawn from below the filter paper to aid in the collection of dust particles. After the vehicle traversed a test section at a constant speed, the filter paper was removed from the Dustometer and placed in a pre-weighed bag to be taken to the laboratory for gravimetric analysis.

Aggregate loss measurements were obtained by taking cross-section elevations immediately after construction of test sections and at the end of the study period. The average difference in elevations represented total aggregate loss.

Results suggested that significant reductions in dust emissions were obtained through the use of chemical dust palliatives. However, under high temperatures and low relative humidity, lignosulfonate performed best when compared to calcium chloride and magnesium chloride. Cost analysis showed a significant reduction in maintenance costs due to decreased aggregate replacement for unpaved roads treated with dust suppressants. Furthermore, the CSU Dustometer proved to be a reliable, precise, portable, and inexpensive means for obtaining data on the field performance of various dust control products.

Gillies et al. (1999) conducted a 14-month study in the San Joaquin Valley, CA on the long-term efficiencies of four dust suppressants, including a biocatalyst stabilizer, polymer emulsion, petroleum emulsion with polymer, nonhazardous crude-oil containing 
material, and one untreated control section. The study was performed on a public road with an ADT of 17 vehicles/day. Products were applied to $1640 \mathrm{ft}(500 \mathrm{~m})$ test sections.

One week prior to applications, the test route was serviced by the local public works department in accordance with the department's standard unpaved road maintenance practices. The biocatalyst stabilizer was applied through a mix-in procedure in which the unpaved surface was regraded, followed by mixing of the product with the soil. For the polymer emulsion, the surface was wet with water, sprayed with a dilute solution of product, and finished with a concentrated solution of product. For the petroleum emulsion with polymer, the road was regraded, followed by wetting of the surface with water and a topical application of product. For the nonhazardous crude-oilcontaining material, the product was thoroughly mixed with the aggregates prior to placement. The mixture of aggregates and product was then brought to the test section, and subsequently graded and compacted. The nonhazardous crude-oil-containing material was applied three months after the biocatalyst stabilizer, polymer emulsion, and petroleum emulsion with polymer, resulting in an 8-month rather than a 12-month evaluation period for this product.

Evaluation of suppressant performance involved the use of surface characterization measurements and emissions tests. Roadway surface properties were measured from July 1995 through August 1996 to determine change as a result of traffic and weather. Measurements obtained included bulk surface loading, suspendable dust loading, aggregate size distributions, moisture content, and surface strength. The bulk surface loading procedure involved sweeping loose aggregates across the width of the road with a fine-bristled brush. Bulk surface loading was then estimated by dividing the 
mass of the collected material by the area from which the sample was removed. The suspendable dust loading was estimated by dividing the mass of the portion of fines (particles $<75 \mu \mathrm{m}$ geometric diameter) within the collected material by the area from which the sample was removed. Determination of aggregate size distributions followed Cowherd, et al (1990). A knife blade was used to extract a surface soil sample from the road for moisture content analysis. To determine surface strength, a penetrometer which measured unconfined compressive strength $\left(\mathrm{N} / \mathrm{cm}^{2}\right)$ was applied at points across the surface of each test section.

Emissions tests were performed using $\mathrm{PM}_{10}$ sampling arrays consisting of 12 MiniVol $\mathrm{PM}_{10}$ samplers per test section. The sampling arrays were located at the midpoint of each test section to reduce the effects of suppressant material tracked on from adjacent section(s). A 3/4-ton pickup truck periodically traversed each test section, at a constant speed, for 100 passes over a six-hour sampling interval to create $\mathrm{PM}_{10}$ emissions.

Results from emissions tests indicated that the polymer emulsion was the most effective suppressant, exceeding $80 \%$ average efficiency in reduction of emissions during the final measurement period, 12 months after application. The nonhazardous crude-oilcontaining material was $95 \%$ efficient after 8 months, and the petroleum emulsion with polymer was $49 \%$ efficient after 12 months. The biocatalyst stabilizer showed rapid deterioration throughout the study period and was only $33 \%$ efficient during the initial measurement period, one week after application. After 12 months there was no significant difference among the efficiency of the biocatalyst stabilizer and the untreated control section. Furthermore, the data suggest that the decline in efficiency of each 
product over the one year evaluation period can be represented as a linear function of time. Results also conclude that the major surface properties that define well-suppressed surfaces are surface silt loading and the strength and flexibility of suppressant material as a surface layer or cover.

A study performed by Morgan et al (2005) in Ames, Iowa compared the performance of three commercially available dust suppressants (lignosulfonate, calcium chloride, and soybean oil soapstock) over a period of 16 weeks. Products were applied to $1000 \mathrm{ft}$ test sections on four public unpaved roads throughout the region, representing both high and low traffic volumes. The relative effectiveness of each product was assessed using quantitative field measurements in which the mean value of dust collected on treated sections was compared to that of untreated controls. The primary method of dust collection involved the use of the Colorado State University Dustometer developed by Sanders and Addo (2000). Results of the study showed that the lignosulfonate outperformed calcium chloride and soybean oil soapstock on all four test routes. Also, the use of dust suppressants reduced the cost of annual road maintenance by up to $75 \%$.

Rushing et al (2006) conducted a 90-day evaluation of commercially available and experimental dust palliatives near Douglas, Arizona. The evaluation included several products, such as polymer emulsions, lignosulfonates, chloride salts, synthetic fluids, an asphalt emulsion, a polysaccharide solution, a polyacrylamide, and a guar gum. Each product was placed on an individual $500 \mathrm{ft}$ by $20 \mathrm{ft}$ test section at the same application rate. Construction of test sections involved grading, applying dust suppressants, scarifying, compacting, and reapplying dust suppressants. Of the 14 test sections constructed, 12 were treated with commercially available dust palliatives, one was treated 
with an experimental product developed by the Naval Research Laboratory, and one section was treated only with water to serve as a control. Evaluation of product performance was achieved using four methods: dust collection using a stationary device, dust collection using a mobile device, visual ratings of dust emissions, and visual inspections of surface conditions.

A stationary dust collector consisted of a filter placed over a wire mesh screen through which a slight vacuum pressure was drawn using an electric vacuum pump. Two stationary devices were located at the midpoint of each test section, spaced approximately $20 \mathrm{ft}$ apart. A sport utility vehicle then made ten passes at a target speed of $30 \mathrm{mi} / \mathrm{h}$ on each test section to accumulate a necessary amount of dust on the filters to facilitate data analysis.

Additional dust collection was performed using a mobile dust collection device developed by Midwest Research Institute. This collection device mounted to a $21 \mathrm{ft}$ long aluminum beam attached to the bed of a pickup truck. A 1.5 in. diameter intake nozzle faced the rear of the vehicle at a distance of $8 \mathrm{ft}$ behind the tailgate and $3 \mathrm{ft}$ above the ground. Dust which was deposited into the atmosphere by the moving vehicle entered through the intake nozzle of the device and settled onto a filter paper. A vacuum was also drawn within the device to aid in the collection of dust onto the filter paper.

After a vehicle pass, visual ratings were assigned to each section, based on a scale of one to ten, to provide a measure of the percentage of visibility retained directly behind the vehicle. Surface conditions were also examined periodically and a numerical value, ranging from one to ten, was assigned to each section indicating the percentage of 
aggregate dislodged from the road. Each rating system was intended to supplement and validate the particulate collection systems.

The four methods for evaluating product performance yielded similar results. Each product was distinguished as excellent, moderate, or poor dust palliation. Products which performed excellently were polymer B, polymer C, brine, polysaccharide, and synthetic B. Products which performed moderately were lignosulfonate B, asphalt emulsion, polymer D, synthetic A, and polymer A. Products which performed poorly were polyacrylamide, lignosulfonate A, and guar gum. Since the evaluation procedures yielded dissimilar test results for products with very similar chemical composition, the researchers were unable to recommend a particular product type.

Oscarsson (2007) performed a field evaluation of various dust suppressants in four different geographic regions of Sweden: Umeå, Rättvik, Hagfors, and Halmstad. In each region, dust suppressants were applied to $3281 \mathrm{ft}$ (1000 m) test sections. Magnesium chloride solution, calcium chloride solution, magnesium chloride flakes, calcium chloride flakes, lignosulfonate, and a solution of starch were evaluated at each test location. Additionally, a bitumen emulsion and biomass were tested in Hagfors and rapeseed oil in Halmstead.

The relative performance of each dust suppressant was evaluated using a vehiclemounted aerosol monitor in combination with visual assessments. The TSI DustTrak aerosol monitor used a light scattering laser diode to determine mass concentration of dust particles on a given test section when traversing at a constant speed.

Results indicated that among all dust suppressants evaluated, calcium chloride and magnesium chloride in solution performed most efficiently. It was also revealed that 
solid calcium chloride was on average $19 \%$ more effective at reducing dust emissions than an equivalent amount of solid magnesium chloride. Dust suppressants which worked by creating hard surface crusts, such as lignosulfonate and bitumen emulsion, performed well initially but later ruptured and became ineffective. Sections treated with starch and biomass also proved to be ineffective at controlling fugitive dust.

A field evaluation comparing the relative performance and costs of various commercially available dust palliatives was conducted by Johnson and Olson (2009) on a variety of subject roads located in northwest, east-central, and southwest parts of Minnesota over a period of two years. Treatments of calcium chloride, magnesium chloride, and organic polymer-plus-binder were evaluated using standard application rates during the first year and variable rates during the second year. Traffic levels varied from average daily traffic of 25 to 700.

The protocol for performance of products' included analysis of samples obtained from both treated and control sections. Parameters for evaluation included moisture content, moisture content control efficiency, measurement from a mobile dust collection device, dust control efficiency, percent passing $0.075 \mathrm{~mm}$ (\#200) sieve, sand equivalent, treatment age, and treatment application rate. The dust collection device used in this experiment was based on the Colorado State University Dustometer but included minor modifications to suit the test vehicle.

Measurements indicated that sections treated with dust suppressants produced less measurable dust than untreated control sections. Participating MnDOT engineers also noted that frequency of maintenance operations on treated sections was reduced by approximately fifty percent. It was shown that aggregate surface moisture content was 
the best predictor of dust control efficiency, and dust levels decreased with increased moisture. Also, dust control efficiency was maximized when moisture content was between three and four percent. Additionally, results showed that a negative correlation existed between control efficiency and sand equivalency, indicating that treatments performed on sandy gravels would be less effective.

\subsection{SUMMARY OF DUST CONTROL PRODUCT RESEARCH}

The results produced by the cited studies are summarized in Table 2.7. In general, calcium chloride was ranked either first or second in all studies which included this product type. Products that formed a hard surface crust were effective for limited duration; after a period of time the crust would break down and the treatment lost effectiveness. Mobile dust monitoring equipment was used on five of the seven experiments. The CSU Dustometer type device was used in three experiments. 
Table 2.7 Summary of Previous Studies on Chemical Dust Palliatives

\begin{tabular}{|c|c|c|c|}
\hline Study & Dust Palliatives Evaluated & $\begin{array}{c}\text { Relative Ranking of } \\
\text { Products }\end{array}$ & Measurement Method(s) \\
\hline $\begin{array}{c}\text { Gebhart et al } \\
\text { (1996) }\end{array}$ & $\begin{array}{l}\text { - Calcium chloride } \\
\text { - Calcium lignosulfonate } \\
\text { - Polyvinyl acrylic polymer emulsions } \\
\text { - Soybean feedstock processing by-products }\end{array}$ & $\begin{array}{l}\text { 1. Calcium chloride } \\
\text { 2. Calcium lignosulfonate } \\
\text { 3. Soybean processing by- } \\
\text { products } \\
\text { 4. Polyvinyl acrylic polymer } \\
\text { emulsions }\end{array}$ & $\begin{array}{l}\text { - Oil-coated dust collection } \\
\text { pans } \\
\text { - Photographic images }\end{array}$ \\
\hline $\begin{array}{l}\text { Sanders and } \\
\text { Addo (1997) }\end{array}$ & $\begin{array}{l}\text { - } \text { Calcium chloride } \\
\text { - Magnesium chloride } \\
\text { - Lignosulfonate }\end{array}$ & $\begin{array}{l}\text { 1. Lignosulfonate } \\
\text { 2. Calcium chloride } \\
\text { 3. Magnesium chloride }\end{array}$ & $\begin{array}{l}\text { - } \text { Mobile dust sampler (CSU } \\
\text { Dustometer) } \\
\text { - Aggregate loss } \\
\text { measurements by way of } \\
\text { land surveying }\end{array}$ \\
\hline $\begin{array}{l}\text { Gillies et al } \\
\text { (1999) }\end{array}$ & $\begin{array}{l}\text { - Biocatalyst stabilizer } \\
\text { - Polymer emulsion } \\
\text { - Petroleum emulsion with polymer } \\
\text { - Nonhazardous crude-oil containing material }\end{array}$ & $\begin{array}{l}\text { 1. Polymer emulsion } \\
\text { 2. Nonhazardous crude-oil } \\
\text { containing material } \\
\text { 3. Petroleum emulsion with } \\
\text { polymer } \\
\text { 4. Biocatalyst stabilizer }\end{array}$ & $\begin{array}{l}\text { - } \text { Bulk surface loading } \\
\text { - Suspendable dust loading } \\
\text { - Aggregate size distributions } \\
\text { - Moisture analysis } \\
\text { - Surface strength } \\
\text { - Emissions tests }\end{array}$ \\
\hline $\begin{array}{l}\text { Morgan et al } \\
\text { (2005) }\end{array}$ & $\begin{array}{ll}\text { - } & \text { Lignosulfonate } \\
\text { - } & \text { Calcium chloride } \\
\text { - } & \text { Soybean oil soapstock }\end{array}$ & $\begin{array}{l}\text { 1. Lignosulfonate } \\
\text { 2. Calcium chloride, } \\
\text { soybean oil soapstock }\end{array}$ & $\begin{array}{l}\text { - Mobile dust sampler (CSU } \\
\text { Dustometer) }\end{array}$ \\
\hline
\end{tabular}




\begin{tabular}{|c|c|c|c|}
\hline $\begin{array}{c}\text { Rushing et al } \\
\text { (2006) }\end{array}$ & $\begin{array}{l}\text { - Polymer emulsions } \\
\text { - Lignosulfonates } \\
\text { - Salt brine (mixture of calcium, magnesium, } \\
\text { - } \text { and sodium chlorides) } \\
\text { - Synthetic fluids } \\
\text { - Asphalt emulsion (CSS-1) } \\
\text { - Polysaccharide solution } \\
\text { - } \text { Polyacrylamide } \\
\text { - Guar gum }\end{array}$ & $\begin{array}{l}\text { 1. Polymer B, polymer C, } \\
\text { salt brine, polysaccharide } \\
\text { solution, synthetic B } \\
\text { 2. Lignosulfonate B, asphalt } \\
\text { emulsion, polymer D, } \\
\text { synthetic A, polymer A } \\
\text { 3. Polyacrylamide, } \\
\text { Lignosulfonate A, guar } \\
\text { gum }\end{array}$ & $\begin{array}{l}\text { - Stationary dust collectors } \\
\text { - Mobile dust collector } \\
\text { - Visual ratings on levels of } \\
\text { dust obscuration per vehicle } \\
\text { pass } \\
\text { - Surface condition ratings }\end{array}$ \\
\hline $\begin{array}{c}\text { Oscarsson } \\
\text { (2007) }\end{array}$ & $\begin{array}{l}\text { - Magnesium chloride solution } \\
\text { - Calcium chloride solution } \\
\text { - Magnesium chloride flakes } \\
\text { - Calcium chloride flakes } \\
\text { - Lignosulfonate } \\
\text { - Starch solution } \\
\text { - Bitumen emulsion } \\
\text { - Biomass }\end{array}$ & $\begin{array}{l}\text { 1. Calcium chloride } \\
\text { solution, magnesium } \\
\text { chloride solution } \\
\text { 2. Calcium chloride flakes } \\
\text { 3. Magnesium chloride } \\
\text { flakes } \\
\text { 4. Lignosulfonate, bitumen } \\
\text { emulsion } \\
\text { 5. Starch solution, biomass }\end{array}$ & $\begin{array}{l}\text { - Vehicle-mounted aerosol } \\
\text { monitor } \\
\text { - Visual assessments }\end{array}$ \\
\hline $\begin{array}{l}\text { Johnson and } \\
\text { Olson (2009) }\end{array}$ & $\begin{array}{l}\text { - } \text { Calcium chloride } \\
\text { - Magnesium chloride } \\
\text { - Organic polymer-plus-binder }\end{array}$ & N/A & $\begin{array}{l}\text { - } \text { Moisture analysis } \\
\text { - Aggregate size distributions } \\
\text { - Sand equivalency } \\
\text { - Mobile dust collector (based } \\
\text { on CSU Dustometer) }\end{array}$ \\
\hline
\end{tabular}




\section{CHAPTER 3 DUST PALLIATIVE PRODUCT SELECTIONS}

A large number of dust palliatives were available and research has demonstrated many of these are effective. To ensure fair selection of products for inclusion in this study, a set of criteria were established. Then, vendors were contacted and asked to provide information about their respective products relative to the selection criteria. This information was compiled and products were selected which best fit the criteria.

\subsection{CRITERIA FOR PRODUCT SELECTION}

A variety of products were considered for use as dust suppressants in this experiment. Criteria were established to aid in selecting products which would be appropriate to use on this project and on the majority of West Virginia public gravel roads. The criteria evaluated included: manufacturers' product recommendation, expected construction cost, availability, suggested number of applications, application rate, application method, dilution, curing time, expected longevity, and reported limitations. Initially, a list of 35 dust suppressants manufactured by 12 different companies within North America was compiled for review and evaluation.

\subsubsection{Manufacturers' Product Recommendation}

The test route for this experiment is generally representative of a typical West Virginia gravel road, in that the topographic features, surface gravel gradation, and annual maintenance techniques are consistent with those found on county routes throughout much of the state. Product manufacturers were provided with photographs of surface conditions and geotechnical soils data for surface gravel on the test route. 
Vendors were also invited to visit the test route prior to product selection to aid in surface treatment recommendation.

\subsubsection{Expected Construction Cost}

The expected cost criterion includes cost for materials, freight and one application. Cost values shown in Table 3.1 were estimated costs which would be expected for a bid proposal to the Division of Highways on larger-scale projects. These estimates may vary slightly depending on the quantity of desired material and location of project; however these values were sufficient for the purpose of comparison in this experiment.

\subsubsection{Availability}

Shipping costs and time were two factors which played a significant role in product availability. All products considered were distributed within a 150-mile radius of the test route, with the exception of Soiltac which was distributed from Morris, IL approximately 500 miles from the test route. Products distributed throughout other parts of the U.S. were considered for testing but were eliminated due to shipping costs and time required for long-term use by the WVDOH.

\subsubsection{Suggested Number of Applications}

Some products required a secondary, or follow-up, application in addition to a primary application. Secondary applications generally require about $1 / 3$ to $1 / 2$ of the initial amount of product, thus a decrease in the cost of subsequent applications would be expected. In some instances, maintenance applications are recommended to correct localized product deterioration. 


\subsubsection{Application Rate}

The application rates shown in Table 3.1 are manufacturers' suggested application rates of concentrated solution, or effective product, in gallons per square yard.

\subsubsection{Application Method}

Some products were reported to perform better when mechanically mixed into the aggregate surface. This method of mixing is usually performed by using a grader to blade the surface into windrows. Then, the dust control product is sprayed onto the aggregate surface. The grader would then spread the windrowed material into a smooth driving surface. The "mix-in" method is usually only performed when a complete gravel road reconstruction is needed, rather than regular maintenance. Due to increased time and costs associated with the "mix-in" method, the WVDOH has requested that only products which can be applied topically be used for the purpose of dust control.

\subsubsection{Dilution}

With the exception of calcium chloride and EK35, each product required dilution with water prior to application. Dilution amounts may vary from 1:1 to $12: 1$, depending on the product used and the amount of dust control needed. Higher concentrations of effective product are often used in areas that necessitate greater amounts of control.

Calcium chloride and EK35 are also diluted into water; however this is most often done at the production plant due to the importance of obtaining exact concentrations of effective product to receive desired levels of field performance.

\subsubsection{Curing Time}

Most products have an associated curing time in which the product undergoes a series of chemical reactions that allows it to set, harden, and develop traits which will 
allow it to persist for weeks. During the curing time it is recommended to keep traffic off of the roadway so that the product may cure properly and to ensure that the dust suppressants do not transfer to a vehicle's surface. A curing time is associated with all products except EK35.

\subsubsection{Expected Longevity}

The expected longevity of various products ranges from about two months to over one year. The impacts of freeze/thaw cycles and winter plowing operations to dust control products on gravel roads has seen only limited investigation. However, it is anticipated that reapplication of dust suppressants would be necessary every year to control nuisance dust on gravel roads.

Historically in West Virginia, the onset of dry weather begins around mid May and spans through mid- to late- August. Therefore, it is necessary that the expected longevity of each product be a minimum of three months in order to last through the majority of a typical dry season in West Virginia.

\subsubsection{Reported Limitations}

Each product has its own unique set of reported limitations. The most common concern, found in nearly every product, is the potential for being an environmental pollutant. The greatest hazard associated with dust control products occurs immediately after product application, during the curing process. Most commonly, pollution occurs when a heavy rainfall event coincides with product application and causes runoff of product into a nearby watershed. Hazards associated with pollution may also stem from carelessness during application, long-term migration of chemicals into roadside ditches, and adherence of dust suppressants to passing vehicles. 
Table 3.1 List of Potential Dust Suppressants

\begin{tabular}{|c|c|c|c|c|c|c|c|c|c|c|c|}
\hline \multicolumn{2}{|c|}{ Suppressant Category } & \multirow{2}{*}{$\begin{array}{l}\text { Product Name } \\
\text { Calcium Chloride }\end{array}$} & \multirow{2}{*}{$\begin{array}{c}\text { Manufacturer } \\
\text { TETRA } \\
\text { Chemicals }\end{array}$} & \multirow{2}{*}{$\begin{array}{c}\text { Cost (\$/sq yd) } \\
\text { Applied } \\
\\
\$ 0.23\end{array}$} & \multirow{2}{*}{$\begin{array}{c}\begin{array}{c}\text { Suggested } \\
\text { No. of } \\
\text { Applications }\end{array} \\
1 \\
\end{array}$} & \multirow{2}{*}{$\begin{array}{c}\begin{array}{c}\text { Application } \\
\text { Rate (gal/sq } \\
\text { yd) }\end{array} \\
\\
0.36\end{array}$} & \multirow{2}{*}{$\begin{array}{c}\begin{array}{c}\text { Application } \\
\text { Method }\end{array} \\
\begin{array}{c}\text { Surface } \\
\text { Spray }\end{array}\end{array}$} & \multirow{2}{*}{$\begin{array}{c}\text { Dilution } \\
\mathrm{n} / \mathrm{a}\end{array}$} & \multirow{2}{*}{$\begin{array}{c}\text { Curing } \\
\text { Time } \\
1 \text { hour } \\
\max \end{array}$} & \multirow{2}{*}{$\begin{array}{c}\begin{array}{c}\text { Expected } \\
\text { Longevity }\end{array} \\
\begin{array}{c}\text { Summer } \\
\text { season }\end{array} \\
\end{array}$} & \multirow{2}{*}{$\begin{array}{c}\text { Reported Limitations } \\
\text { Potential for corrosion. Can } \\
\text { create slippery surface if } \\
\text { concentration is too high. }\end{array}$} \\
\hline $\begin{array}{l}\text { Water } \\
\text { Absorbing }\end{array}$ & $\begin{array}{l}\text { Calcium } \\
\text { Chloride } \\
\text { Liquid }\end{array}$ & & & & & & & & & & \\
\hline $\begin{array}{l}\text { Organic } \\
\text { Petroleum }\end{array}$ & $\begin{array}{l}\text { Polymer Mod. } \\
\text { Asphalt } \\
\text { Emuls. }\end{array}$ & Pennz Suppress & $\begin{array}{l}\text { American } \\
\text { Refining Group }\end{array}$ & $\$ 1.20$ & 2 & 0.15 & $\begin{array}{l}\text { Surface } \\
\text { Spray, mix } \\
\text { in }\end{array}$ & $\begin{array}{l}4: 1 \text { or } \\
5: 1\end{array}$ & $\begin{array}{l}1-4 \\
\text { hrs }\end{array}$ & 6 mos. & $\begin{array}{l}\text { Rutting in weak bases, potential } \\
\text { pollutant, apply immediately } \\
\text { after or during grading }\end{array}$ \\
\hline $\begin{array}{l}\text { Organic } \\
\text { Petroleum }\end{array}$ & $\begin{array}{l}\text { Polymer Mod. } \\
\text { Asphalt } \\
\text { Emuls. }\end{array}$ & $\begin{array}{l}\text { Petro Tac } \\
\text { - Initial App. } \\
\text { - Maint. App. }\end{array}$ & $\begin{array}{l}\text { Syntech } \\
\text { Products }\end{array}$ & $\begin{array}{l}\$ 0.54 \\
\$ 0.32\end{array}$ & $\begin{array}{l}1 \\
1\end{array}$ & $\begin{array}{l}0.2 \\
0.1\end{array}$ & $\begin{array}{l}\text { Surface } \\
\text { Spray }\end{array}$ & $\begin{array}{l}3: 1 \\
7: 1\end{array}$ & $\begin{array}{l}1-4 \\
\text { hrs }\end{array}$ & 1-6 mos. & $\begin{array}{l}\text { Rutting in weak bases, potential } \\
\text { pollutant }\end{array}$ \\
\hline $\begin{array}{l}\text { Organic } \\
\text { Petroleum }\end{array}$ & $\begin{array}{l}\text { Polymer Mod. } \\
\text { Non Asph. } \\
\text { Emuls. }\end{array}$ & TechSuppress & $\begin{array}{l}\text { Syntech } \\
\text { Products }\end{array}$ & $\$ 0.85$ & 1.5 & 0.2 & $\begin{array}{l}\text { Surface } \\
\text { Spray }\end{array}$ & $4: 1$ & $\begin{array}{l}1-4 \\
\text { hrs }\end{array}$ & $\begin{array}{l}30-180 \\
\text { days }\end{array}$ & $\begin{array}{c}\text { Rutting in weak bases, potential } \\
\text { pollutant }\end{array}$ \\
\hline $\begin{array}{l}\text { Organic } \\
\text { Petroleum }\end{array}$ & $\begin{array}{l}\text { Polymer Mod. } \\
\text { Asphalt } \\
\text { Emuls. }\end{array}$ & Ultra Bond 2000 & JMG Emulsions & $\$ 0.90$ & 2 & $0.25-0.50$ & $\begin{array}{l}\text { Surface } \\
\text { Spray }\end{array}$ & $5: 1$ & $\begin{array}{l}24-48 \\
\text { hrs }\end{array}$ & 6 mos. & $\begin{array}{c}\text { Rutting in weak bases, potential } \\
\text { pollutant }\end{array}$ \\
\hline $\begin{array}{l}\text { Organic } \\
\text { Petroleum }\end{array}$ & $\begin{array}{l}\text { Synthetic } \\
\text { Organic Fluid }\end{array}$ & EK35 & $\begin{array}{c}\text { Midwest } \\
\text { Industrial Supply }\end{array}$ & $\$ 1.42$ & $\begin{array}{l}1-2 \text { (2nd app } \\
\text { use } 1 / 2 \\
\text { gallons) }\end{array}$ & 0.14 & $\begin{array}{l}\text { Surface } \\
\text { Spray }\end{array}$ & $\mathrm{n} / \mathrm{a}$ & $\begin{array}{l}\text { Does } \\
\text { not } \\
\text { cure }\end{array}$ & $\begin{array}{l}6-12 \\
\text { mos. }\end{array}$ & Initial costs are higher \\
\hline $\begin{array}{l}\text { Organic } \\
\text { Non } \\
\text { Petrol. }\end{array}$ & Lignosulfonate & Dust Fyghter & $\begin{array}{l}\text { Midwest } \\
\text { Industrial Supply }\end{array}$ & $\$ 0.60$ & 2 & .32 & $\begin{array}{l}\text { Surface } \\
\text { Spray }\end{array}$ & $1: 1$ & $\begin{array}{c}8-12 \\
\text { hrs }\end{array}$ & $\begin{array}{l}8-12 \\
\text { wks. }\end{array}$ & $\begin{array}{l}\text { Longevity could vary, potential } \\
\text { pollutant }\end{array}$ \\
\hline $\begin{array}{l}\text { Synth. } \\
\text { Polymer } \\
\text { Emuls. }\end{array}$ & $\begin{array}{l}\text { Polyvinyl } \\
\text { Acetate }\end{array}$ & Soiltac & Soilworks & & 1 & 1.03 & $\begin{array}{l}\text { Surface } \\
\text { Spray }\end{array}$ & $7: 1$ & & $1+$ years & $\begin{array}{l}\text { Clean up and disposal } \\
\text { concerns after application. }\end{array}$ \\
\hline
\end{tabular}




\subsection{SELECTED PRODUCTS}

After review, only eight products met all guidelines within the established criteria. Of the eight potential products, five were selected for use in this trial. Table 3.1 lists the eight potential products along with a summary of selection criteria.

The five products recommended for use in this trial were: calcium chloride, petroleum emulsion with polymer (Petro Tac), bituminous resin pitch (TechSuppress), synthetic organic fluid (EK35), and lignosulfonate (Dust Fyghter). Each product fulfilled all requirements within the established criteria.

Products which the researchers suggested should be removed from further consideration in this trial were PennzSuppress, Ultra Bond 2000, and Soiltac. Three of the potential products are polymer modified asphalt emulsions. PennzSuppress and Ultra Bond 2000 were eliminated from evaluation simply because they were more costly than Petro Tac. Soiltac, however, was removed from consideration because it did not meet the criteria for product availability.

The nearest product distributor for Soiltac was approximately 500 miles from West

Virginia in Morris, IL. Shipping costs from the Morris, IL facility account for nearly 17 percent of material costs. There were also application concerns associated with Soiltac. There were no local applicators that were willing to apply Soiltac at the time of this experiment due to its potential for harming application equipment. 


\section{CHAPTER 4 DEMONSTRATION SITES}

\subsection{CRITERIA FOR TEST ROUTE SELECTION}

A list of eight potential gravel road test sections in Wood County, WV was provided by the WVDOH District Three Maintenance Engineer. The selection of a test section depended upon a variety of criteria. Among the criteria were: a history of customer complaints regarding road dust, section length, relative amounts of shaded areas, roadway linearity, surface gravel condition and uniformity, surrounding agricultural land use, and safety during application. An inventory assessment form, Figure 4.1, and a condition survey, Figure 4.2, were prepared to assist in the collection of data to assess the criteria for selection of a test section. After the selection of a test route, a survey was conducted to assess the opinions of citizens living adjacent to the road regarding the condition of the road during the dry season.

\subsubsection{Potential Test Routes}

The eight potential gravel road test routes that were evaluated on May 19, 2010 are identified in Table 4.1. These routes were selected because the WVDOH has received numerous complaints from citizens who travel along and live adjacent to these roads. The three Buck Run roads were treated as a single potential test route. 
Table 4.1 Potential Gravel Road Test Routes

\begin{tabular}{|c|c|c|c|}
\hline Road Name & Co. Route No. & Begin MP & End MP \\
\hline Right Fork Buck Run & $21 / 24$ & 0.00 & 1.27 \\
\hline Right Fork Buck Run & $44 / 5$ & 0.00 & 0.59 \\
\hline Left Fork Buck Run & $46 / 7$ & 0.00 & 2.04 \\
\hline Cam Run Road & $26 / 3$ & 0.12 & 1.57 \\
\hline Oak Grove Road & $7 / 1$ & 0.00 & 3.32 \\
\hline Elk Run Road & $17 / 1$ & 0.00 & 1.05 \\
\hline Little Pond Creek & $9 / 23$ & 0.00 & 0.35 \\
\hline Price Road & $14 / 3$ & 0.73 & 1.28 \\
\hline
\end{tabular}

\subsubsection{Route Length}

The road must have a length great enough to accommodate five treated test sections and four untreated control sections, each spanning a length of 1320 linear feet ( 0.25 miles). The FHWA Gravel Roads Maintenance and Design Manual suggested using 500 to $1000 \mathrm{ft}$. test sections. Sanders (personal communication) noted that in order to obtain measurable amounts of dust during data collection with the mobile dust collection apparatus, the total length traversed during data collection for one section should be approximately one mile. However, multiple passes with the dust collector can be made to accommodate the one mile length requirement. Therefore, each test section will be $1320 \mathrm{ft}$ (0.25) miles in length and the procedure for data collection shall be adjusted accordingly to account for the section length requirement suggested by Sanders. Also, transition areas are to be located between each test section to allow for acceleration and deceleration of the test vehicle during dust collection and to eliminate tracking of products to adjacent test sections. The length of these transition areas was estimated to be 180 linear feet. This accounts for nine test sections within the test route, spanning a total length of 13,500 linear feet or about 2.6 miles. 


\subsubsection{Relative Amounts of Shaded Areas}

It is likely that test areas which have higher relative amounts of sunlight will create drier, and thus, drier gravel surfaces. Therefore it is possible that areas which receive greater amounts of sunlight could produce dustier surfaces. Consideration was given for heavily shaded areas, as this factor could have significantly affected the performance of materials throughout the evaluation period.

\subsubsection{Roadway Linearity}

Ideally, a test section would be as straight as possible to facilitate data collection. Given the geographic area, however, this expectation seems somewhat improbable. Though, one primary goal was to select a section which was as straight as possible.

\subsubsection{Surface Gravel Condition and Uniformity}

There is a need for the section to have both "good" surface gravel and relatively uniform gradation throughout the entire length of the section. The gravel itself must have a good gradation- particularly a desirable percentage of fine material with some plasticity in order to give the gravel a natural binding characteristic. Samples of surface gravel from the selected section were collected and analyzed to provide an indication of the existing soil conditions.

Other factors that influence the condition of the surface gravel include: crown condition, drainage condition, thickness of gravel surface layer, corrugations, potholes, and rutting. Included in the Gravel Road Inventory Collection Form, Figure 4.1, is an overall gravel surface rating procedure in which the surveyor rates a road on a scale of one to five, as prescribed by the Pavement Surface Evaluation and Rating (PASER) Manual for Gravel Roads (Gravel-PASER Manual, 2002). Figure 4.2 shows a condition survey which was created to assess each of the factors mentioned previously. If good gravel and adequate drainage conditions were not present 
on the section selected, a recommendation would be submitted to have good, fresh gravel hauled in and to have crowns and ditches repaired prior to treatment as part of the gravel road maintenance process.

Two soil tests were conducted per potential test route: mechanical sieve analysis (ASTM D422) and Atterburg limits tests (ASTM D4318). Mechanical sieve analysis indicates the distribution of particle sizes larger than $75 \mu \mathrm{m}$. Table 2.2 was referenced to ensure that the surface gravel on the potential test route was within WVDOH surface gravel gradation specifications. Atterburg limits test methods cover the determination of liquid limit (LL), plastic limit (PL), and plasticity index (PI). This test method basically indicates whether the fine material is composed of clays or silts and tells of the cohesive qualities of the soil.

\subsubsection{Surrounding Agricultural Land Use}

Often, there is substantial amount of dust generated by means of various agricultural processes. For this reason, it is important that no agricultural processes producing substantial amounts of airborne dust were located adjacent to test sections, as this factor could significantly affect the results obtained throughout the experiment.

\subsubsection{Personnel Safety}

During the application of treatments, WVDOH agreed to provide traffic control as needed. However, the subsequent assessment of performance of the treatments by the researchers was made without the benefit of traffic control, so good stopping sight distance was important. 
WT LTAP

District 3

West Virginia DOH

Gravel Road Inventory Data Collection Form

Date:

Completed by:

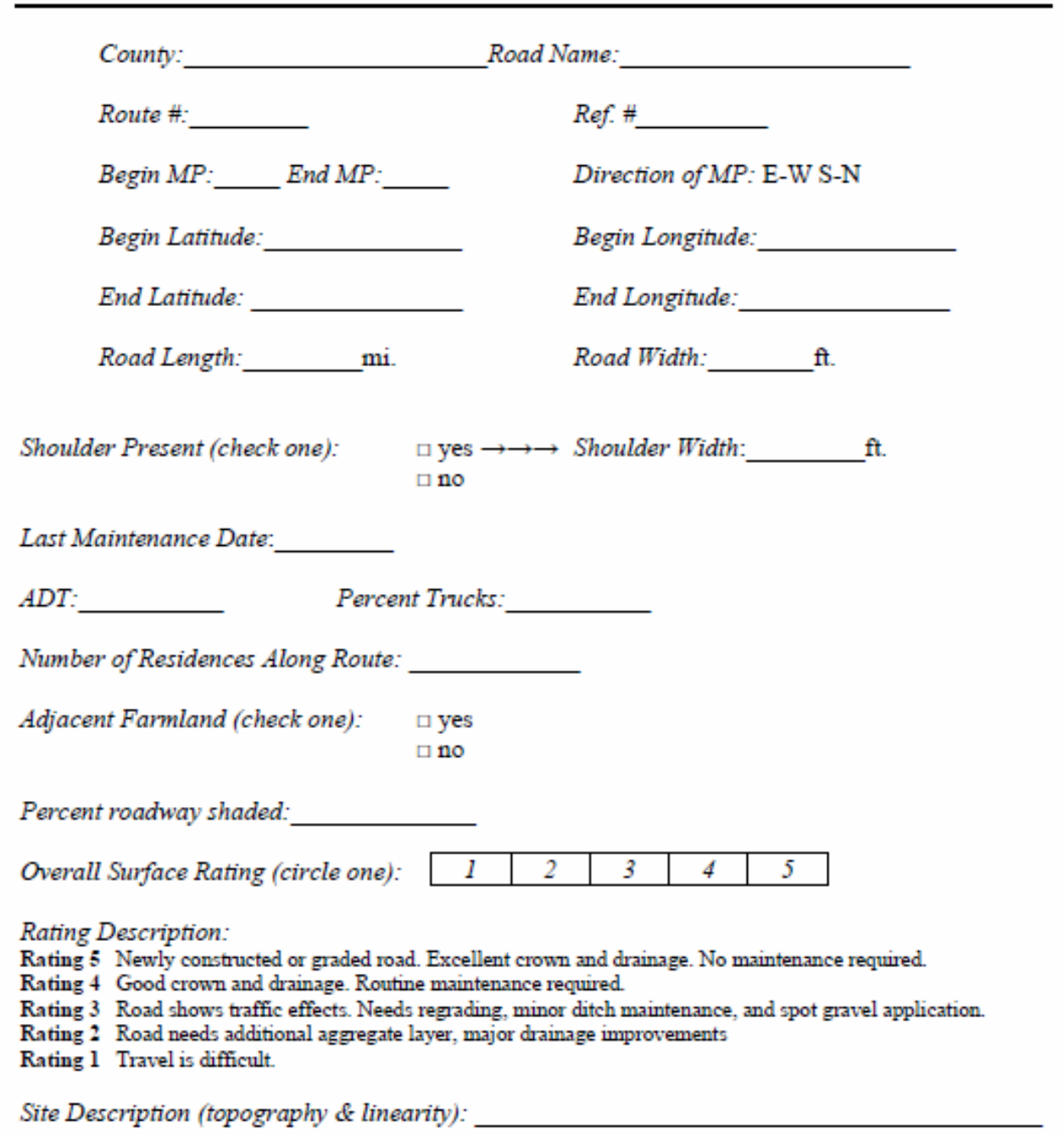

Figure 4.1 Gravel Road Inventory Data Collection Form 
WV LTAP

West Virginia DOH

Gravel Road Condition Survey

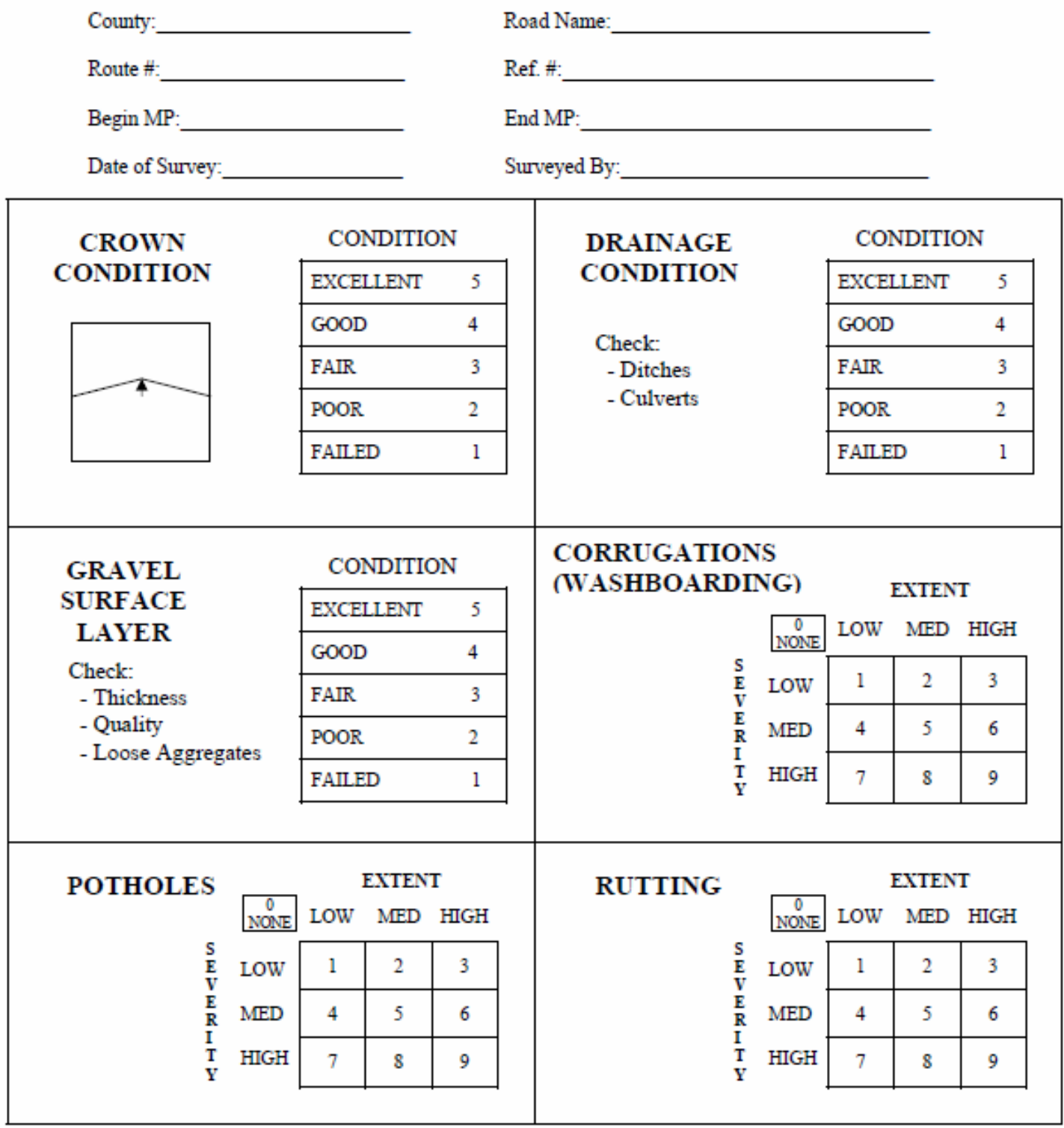

Figure 4.2 Gravel Road Condition Survey 


\subsection{ROUTE SELECTED FOR EXPERIMENTAL EVALUATION}

The dominant criterion for selecting the test route was adequate length for the treatment and control sections. This criterion eliminated all but two potential test routes. The research team and WVDOH engineers performed a field evaluation of the two sites. Based on the selection criteria the Oak Grove Road, CR 7/1, test route was selected.

\subsubsection{Section Length}

Of the eight potential test sections shown in Table 4.1, only Oak Grove Road and Buck Run Road (Left and Right Forks) met the minimum length required for the construction of nine test sections. Therefore, the remaining routes were eliminated from the list of potential test routes because they did not pass the criteria for required section length.

\subsubsection{Surface Gravel Condition and Uniformity}

Surface gravel condition and uniformity was an important factor in the criteria for selecting a test route for this experiment because all of the potential test routes had portions of roadway that were previously surface treated. However upon visual observation, Oak Grove Road contained relatively uniform gravel surface material throughout the entire 3.35 mile route. There were isolated areas on the road which had been previously surface treated. However, there was no surface treatment pavement on the section of the road used for this experiment.

Sieve analyses (performed in accordance with ASTM D 422) of two soil samples taken at random locations along the test route confirmed that both soil samples consisted of relatively well-graded surface gravel and met the surface gravel gradation specifications shown in Table 2.2. Figure 4.3 shows the gradations of surface gravel obtained from soil samples at mile posts (MP) 0.80 and 2.55 , respectively. Other factors observed on Oak Grove Road were: crown condition, drainage condition, thickness of gravel surface layer, corrugations, potholes, and 
rutting, as indicated in the Gravel Road Inventory Data Collection Forms and Gravel Road Condition Surveys, Appendices A and B.

The condition of the road crown, drainage, and gravel surface thickness received a rating of "Fair," and the road received an overall surface rating of three, as prescribed by the Gravel Road Inventory Data Collection Form and the Gravel Road Condition Survey, as shown in Appendices A and B, respectively. Further evaluation of Oak Grove Road revealed that much of the large aggregates in the surface gravel migrated toward the road edge, thereby clogging the roadside ditches in many areas. It is thought that the clogging of ditches in many areas led to the formation of surface distresses such as rutting and potholes in localized areas, Figures 4.4 and 4.5. The WVDOH performed maintenance to repair and smooth Oak Grove Road prior to product application.

\subsubsection{Relative Amounts of Shaded Areas}

It was observed that Oak Grove Road included a high percentage of shaded areas (approximately 85 percent). The section of road from MP 2.27 to MP 2.47 is exposed to sunlight throughout the entire day. This portion of the road was used as one of the four control sections.

\subsubsection{Roadway Linearity}

Oak Grove Road possessed numerous horizontal and vertical curves, including maximum vertical grades of approximately 10 percent. The fact that Oak Grove Road had many horizontal and vertical curves was representative of a typical West Virginia gravel road. 


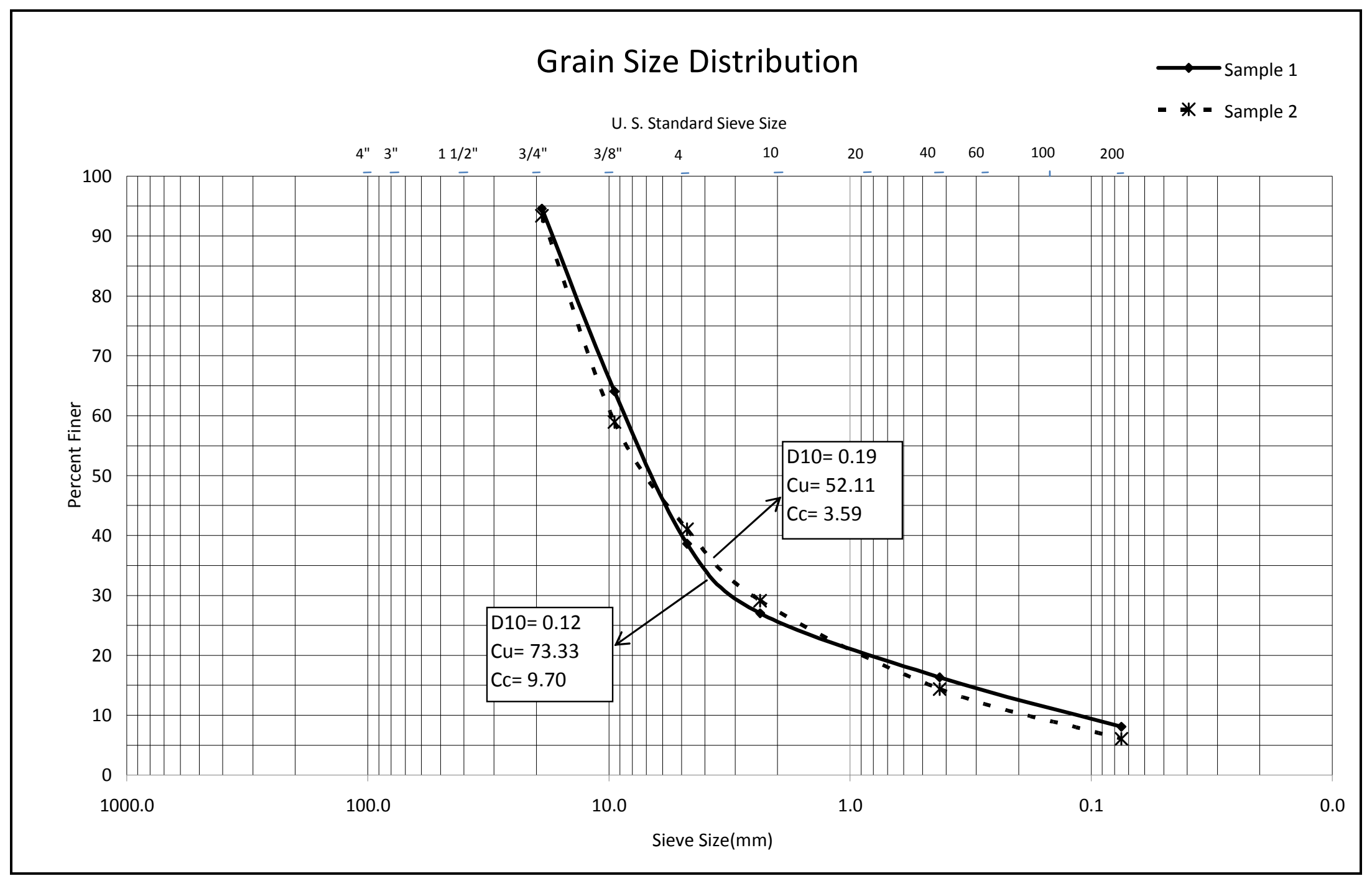

Figure 4.3 Aggregate Gradation Curves for Surface Gravel on Oak Grove Road 


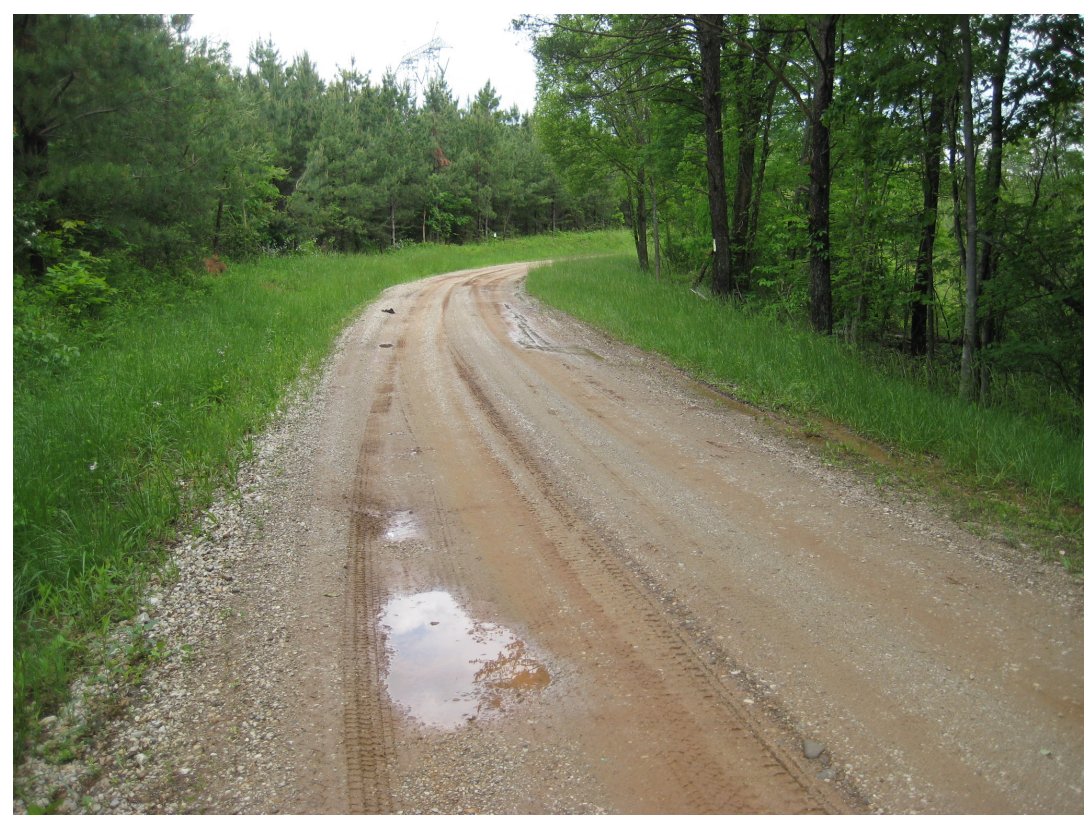

Figure 4.4 Rutting and Potholes on Oak Grove Road Prior to Road Maintenance

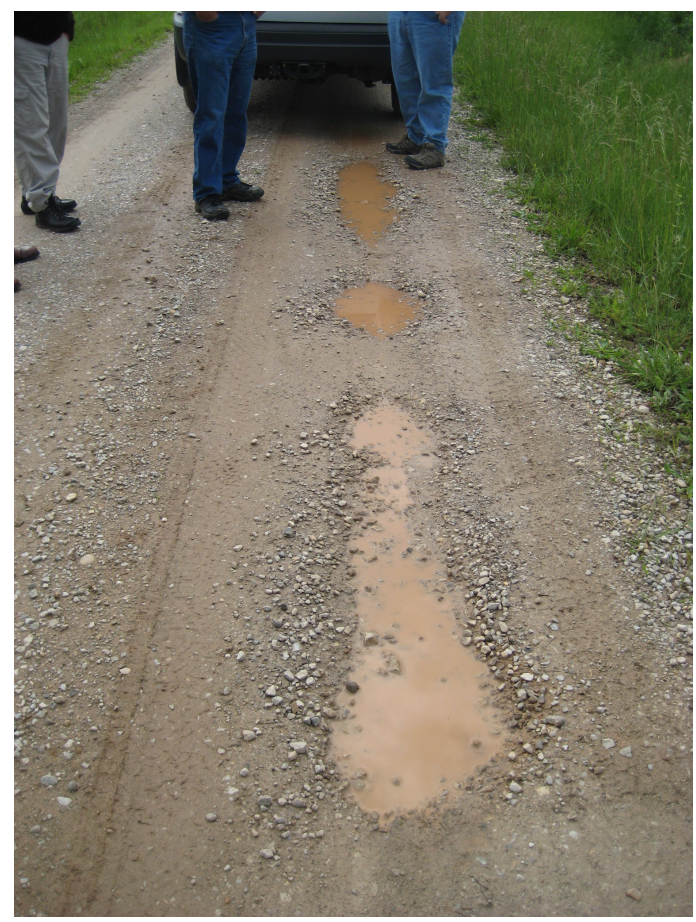

Figure 4.5 Potholes on Oak Grove Road Prior to Road Maintenance 


\subsubsection{Surrounding Agricultural Land Use}

The land adjacent to Oak Grove Road is predominantly covered with forest and a few pasture areas. Furthermore, there are only eight residences along the test route. This type of land use adjacent to the test route is ideal for the experiment as there are no activities that would generate dust during the observation period.

\subsubsection{Personnel Safety}

Due to relatively low average daily traffic (approximately 30 ADT), few residences (8), and the location of Oak Grove Road to other routes which would provide easily accessible detour routes throughout the construction of test sections, the criterion for personnel safety was successfully fulfilled.

\subsubsection{Survey Results of Citizens Living Adjacent to Test Route}

Surveys conducted of citizens living adjacent to Oak Grove Road (CR 7/1) yielded mixed results. Of the eight residences along the road, three surveys were returned. Two of three respondents indicated that the amount of dust generated on the test route was noticeable and that they notice dust buildup in/on their residence during the dry season. One of three indicated that they wash/clean their house and car more frequently during the dry season. One of three indicated that someone in the household has asthma or some other respiratory illness. Two of three indicated that someone living in the household has an allergy to dust.

\subsection{CONFIGURATION OF TEST SECTIONS}

Test sections were constructed on Oak Grove Road (CR 7/1), in Walker, WV, the location of which is shown in Figure 4.6. The location of each treatment on the test route was randomly assigned. An untreated control section was located between each treated section. The arrangement of sections is shown in Table 4.2. Each section was $1320 \mathrm{ft}$ in length, with $180 \mathrm{ft}$ 
transition areas between each section. Transition areas allowed for vehicle acceleration during data collection and helped to eliminate any transfer of material from one section to another. The length of transition areas was determined by Equation 4.1. Locations of treatments on the test route are shown in Figure 4.7.

$d_{a}=1.075\left(\frac{S^{2}}{a}\right)$

Where,

$d_{a}=$ acceleration distance, $\mathrm{ft}$

$S=$ speed at the end of acceleration (from a stop), $\mathrm{mi} / \mathrm{h}$

$a=$ acceleration rate, $\mathrm{ft} / \mathrm{s}^{2}$

Table 4.2 Arrangement of Sections on Test Route

\begin{tabular}{|c|c|c|}
\hline $\begin{array}{c}\text { Section } \\
\text { Number }\end{array}$ & Treatment Type & Market Name \\
\hline 1 & Petroleum emulsion with polymer & PetroTac \\
\hline 2 & Untreated control & n/a \\
\hline 3 & Synthetic organic fluid & EK35 \\
\hline 4 & Untreated control & Calcium chloride \\
\hline 5 & Calcium chloride & Tech Suppress \\
\hline 6 & Untreated control & n/a \\
\hline 7 & Bituminous resin pitch & Dust Fyghter \\
\hline 8 & Untreated control & Lignin Sulfonate \\
\hline 9 &
\end{tabular}




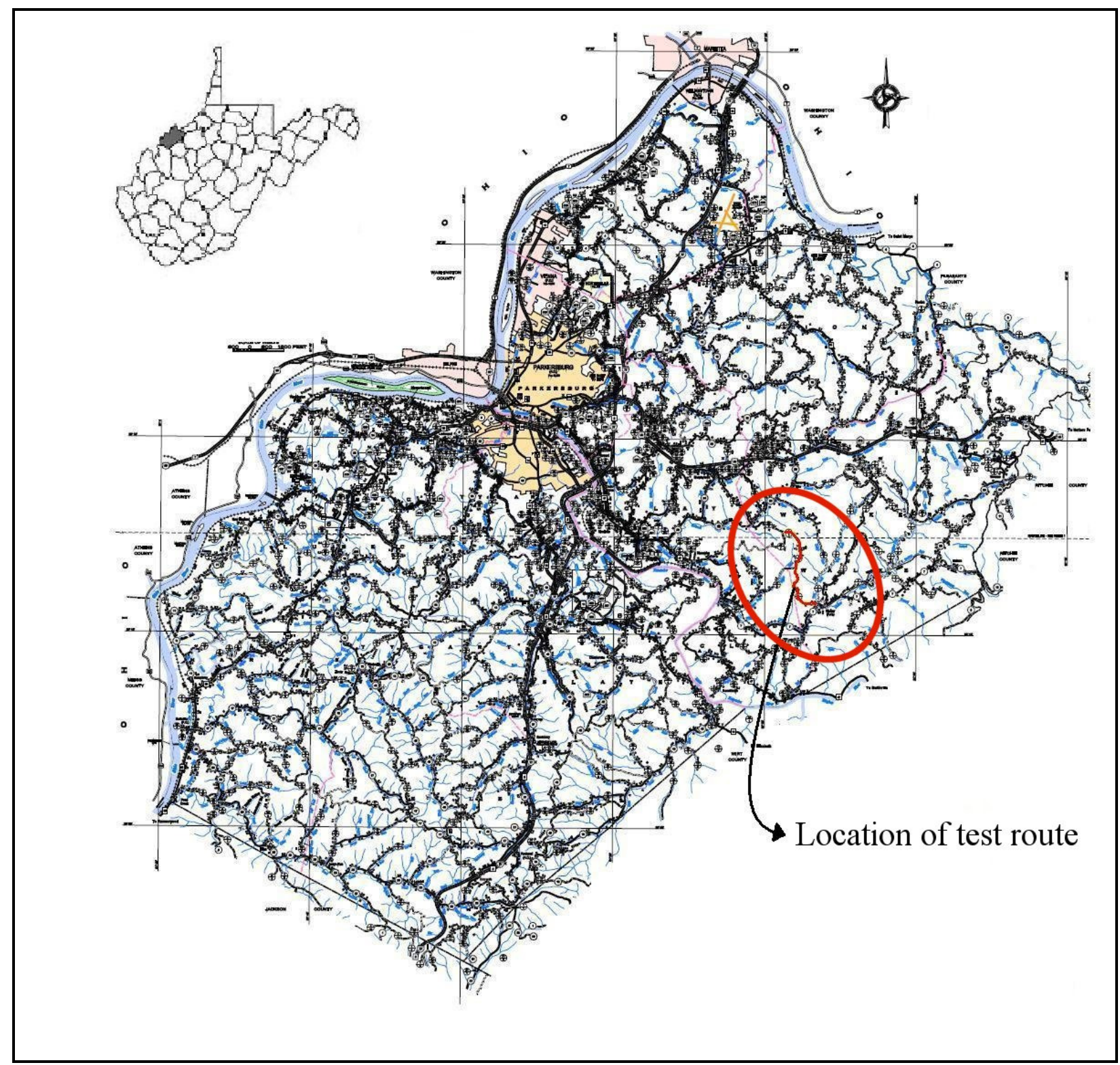

Figure 4.6 Location of Test Route (Oak Grove Road) in Wood County, WV 


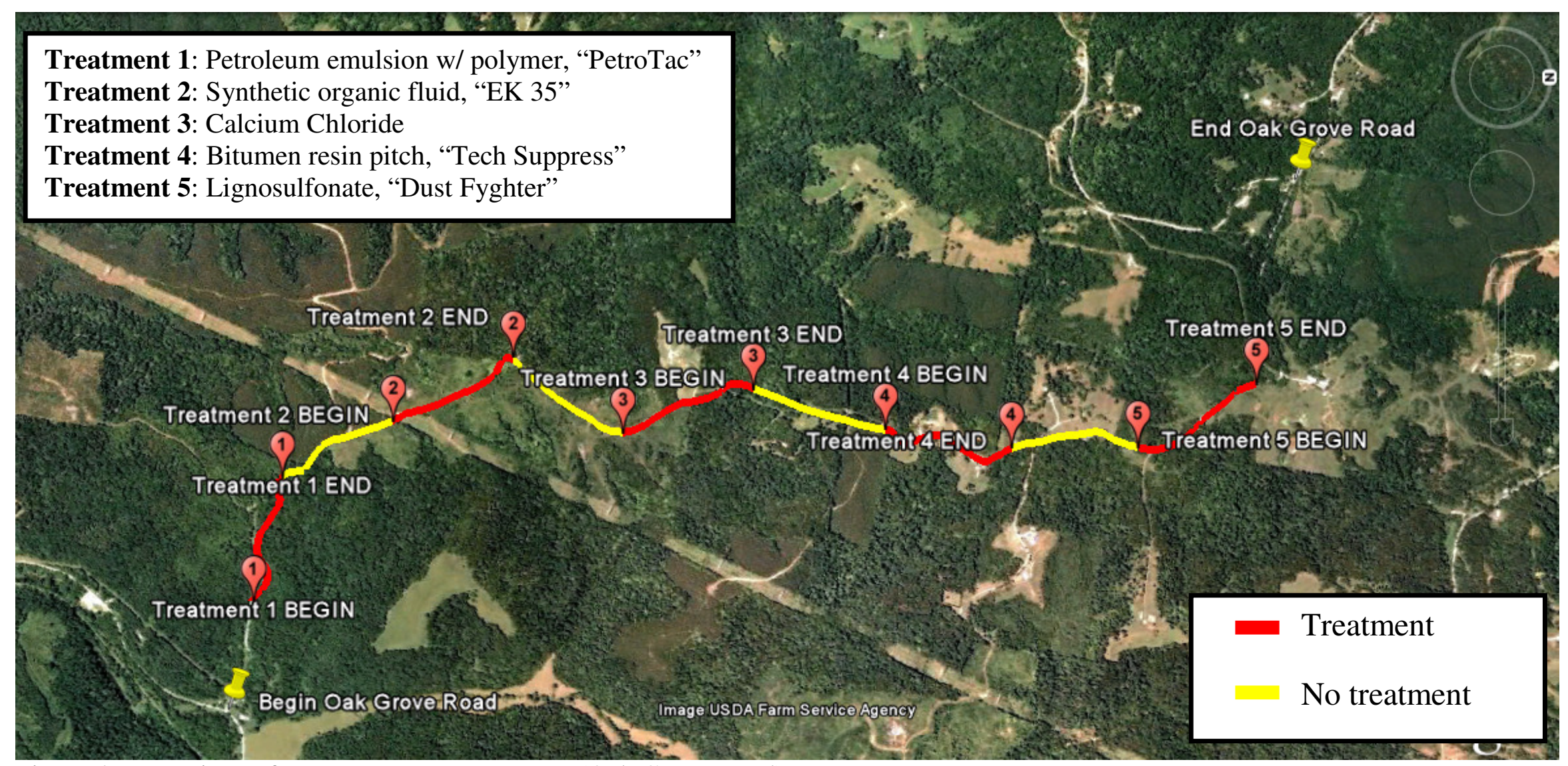

Figure 4.7 Locations of Treatments on Test Route (Oak Grove Road) 


\subsection{APPLICATION OF TREATMENTS}

All products were topically applied to the roadway by vendors during June 28-30, 2010.

A $38 \%$ calcium chloride solution was applied on $6 / 28 / 2010$ at an application rate of $0.38 \mathrm{gal} / \mathrm{yd} 2$. Two passes of the calcium chloride solution were required to achieve the desired application rate. The petroleum emulsion with polymer ("Petrotac") and the bituminous resin pitch ("Tech Suppress") were both applied on 6/28/2010 at application rates of $0.214 \mathrm{gal} / \mathrm{yd}^{2}$. Seven passes of Petrotac and six passes of Tech Suppress were required by the distributor truck to achieve the desired application rates. Follow-up applications of Petrotac and Tech Suppress occurred on 6/29/2010 at application rates of 0.086 and $0.064 \mathrm{gal} / \mathrm{yd}^{2}$, respectively. Five passes of each product were required by the distributor truck to achieve the desired application rates. The vendor of Petrotac and Tech Suppress indicated that secondary applications of these products were necessary to ensure that any aggregates disturbed by traffic movement after the initial application were sufficiently coated with product. The synthetic organic fluid ("EK35") and lignin sulfonate ("Dust Fyghter") were applied on 6/30/2010 at application rates of 0.14 and 0.32 $\mathrm{gal} / \mathrm{yd}^{2}$, respectively. Two passes of each product were required by the distributor truck to achieve the desired application rates. Table 4.3 shows the number of passes required per application for each product, as well as observation recorded during applications. An activity log during the product evaluation period is presented in Appendix C. 
Table 4.3 Number of Passes per Product Application and Observations during Applications

\begin{tabular}{|c|c|c|}
\hline Product & No. Passes/App. & Observations \\
\hline Petrotac & $\begin{array}{c}7 \text { (Initial) } \\
5 \text { (Follow-up) }\end{array}$ & $\begin{array}{l}\text { - Cured within } 8 \text { hours, however few tacky areas } \\
\text { remained } \\
\text { - Material was highly flowable for 1-2 hours } \\
\text { (potential for prduct leaching) }\end{array}$ \\
\hline EK35 & 2 & $\begin{array}{l}\text { - Reddish-brown in color } \\
\text { - Noticeable odor }\end{array}$ \\
\hline Calcium Chloride & 2 & - Completely soaked into road within 1 hour \\
\hline Tech Suppress & $\begin{array}{c}6 \text { (Initial) } \\
5 \text { (Follow-up) }\end{array}$ & $\begin{array}{l}\text { - Uncured after } 8 \text { hours, many tacky areas remained } \\
\text { - Pooled in isolated areas and receive complaints } \\
\text { from residents and passing motorists }\end{array}$ \\
\hline Dust Fyghter & 2 & $\begin{array}{l}\text { - Reddish-brown in color } \\
\text { - Noticeable odor }\end{array}$ \\
\hline
\end{tabular}




\section{CHAPTER 5 MEASUREMENT AND MONITORING}

\subsection{DUST COLLECTION}

There are two basic types of equipment for measuring road dust: static and mobile dust collectors. Static dust collectors are placed along the road side; over time, dust settles into the collectors and periodically the amount of accumulated dust is measured. There are various standards for measuring dust with static collectors, such as ASTM D1759, BS 1747, and AS/NZS 3580. The advantage of static collectors is they provide a measure of the total dust being generated by traffic on the road. They are also relatively inexpensive. Static collectors were given strong consideration for this experiment; a prototype device was constructed. However, after the test site was selected it was determined that the limitation of static collectors was a detriment to their use in this experiment. Their limitations include the potential for vandalism, limited amount of dust generated on a road with $30 \mathrm{ADT}$, and the variable nature of vegetation and trees along the test route could cause variance in the measurements for the different test sections. Hence, static dust collectors were not used.

Mobile dust collectors directly measure the dust generated by a test vehicle. The advantages of this class of devices include readily available results (there is no long-term period for the collection of dust), varying roadside vegetation does not affect measurements, and the vandalism problem is eliminated. The disadvantage of these devices is they do not measure the amount of dust generated along the road side and adjacent land. Mobile devices are limited to measuring relative amounts dust generated near the road surface. Since the objective of this experiment was to compare dust treatments, relative measurements of dust are adequate. 
The Colorado State University Dustometer was developed at Colorado State University (CSU) by Sanders and Addo (2000) for use in a study which measured the relative effectiveness of various dust suppressants. The Dustometer has also been used in subsequent research projects by Iowa DOT and Alaska DOT. Figure 5.1 shows a simple schematic diagram of the CSU Dustometer. It is a moving dust collection device which is mounted on the bumper of a pickup truck. A suction pump draws air through an opening which faces the rear tire of the vehicle. Dust which is drawn through the opening of the filter box settles on filter paper. The filter paper is removed after each pass of a test section and taken to the laboratory to obtain a measurement of the amount of dust collected for each section (in grams/mile).

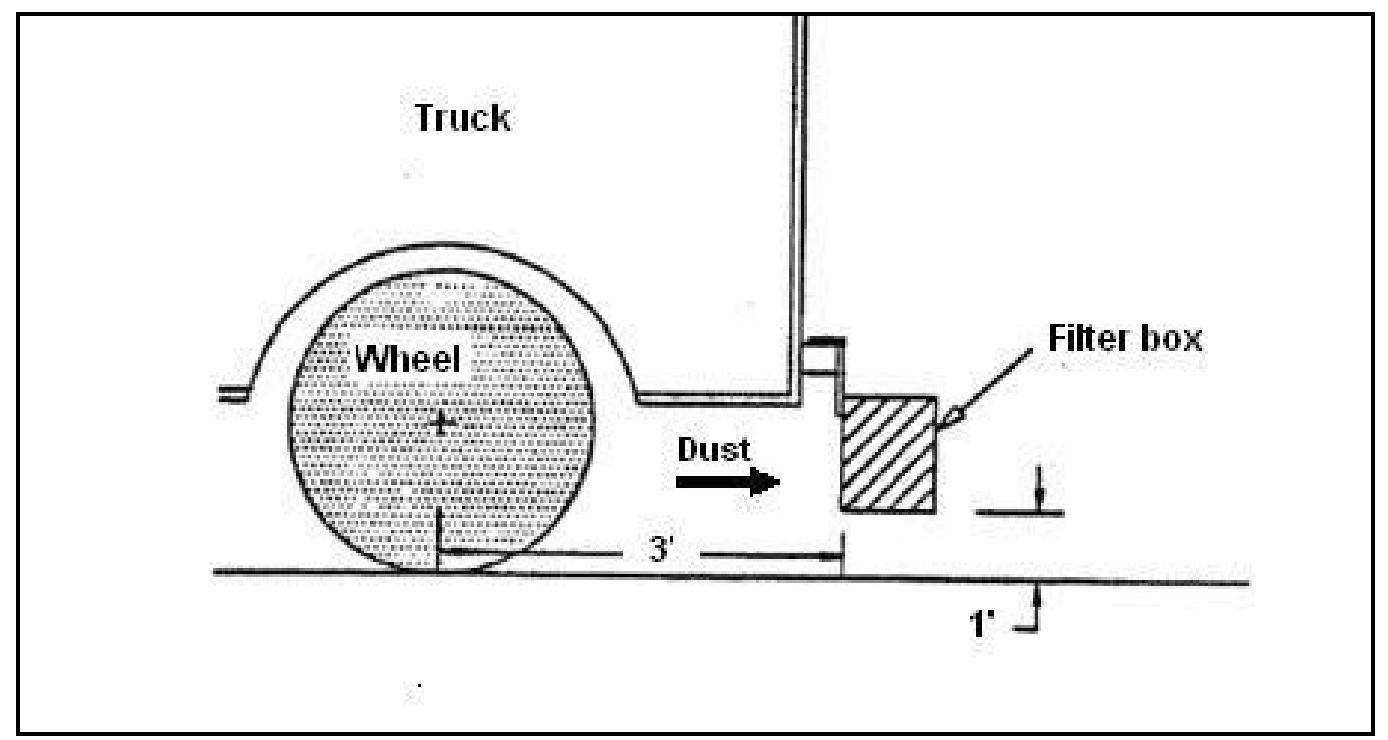

Figure 5.1 Schematic of Colorado State University Dustometer

Sanders and Addo (2000) verified the precision of the Dustometer by performing nine replicate sample measurements, at $45 \mathrm{mph}$, on a one mile untreated test section. A mean of $2.85 \mathrm{~g}$ was obtained with a standard deviation of 0.21 , variance of 0.04 , and coefficient of variation of $7 \%$. Additional dust measurements conducted on the same untreated test section at speeds ranging from 20 to $50 \mathrm{mph}$ indicate that a linear relationship (with $\mathrm{R}^{2}=0.98$ ) exists between vehicle speed and the amount of dust generated. 
The CSU Dustometer consisted of a metal box containing a $10 \times 8$ in $(25.4$ x $20.3 \mathrm{~cm})$ glass fiber filter paper, mounted onto the bumper of a $3 \frac{4}{4}$ ton pickup truck behind the driver's side rear tire; a gas-powered electric generator; and a high-volume vacuum pump. The metal filter box had a $12 \times 12$ in $(30.5 \times 30.5 \mathrm{~cm})$ opening covered with a $450 \mu \mathrm{m}$ sieve screen, intended to prevent any non-dust particles from entering and settling onto the filter paper.

The mobile dust sampler developed for use within this study had the same basic operating principles as the CSU Dustometer, but incorporated changes to ease construction and increase efficiency. This mobile dust collector consisted of a $3 / 4$ in plastic-laminated engineered wood box containing a $10 \times 8$ in $(25.4 \times 20.3 \mathrm{~cm})$ glass fiber filter paper, mounted to the bumper of a $1 \frac{1}{2}$ ton pickup truck behind the driver's side rear tire; a 1000 watt DC to AC power inverter mounted within the cab; a 1.0 horsepower high-volume vacuum pump, producing $115 \mathrm{cfm}$ at 6.2 amperes; a 2 1/4" diameter flexible air hose connecting the vacuum pump and filter box; and an "ON/OFF" switchbox connecting the power inverter to the vacuum pump. Figure 5.2 shows the filter box mounted to the test vehicle with the vacuum attached. The filter box had a $10 \mathrm{x} 10$ in $(25.4 \mathrm{x}$ $25.4 \mathrm{~cm}$ ) opening covered with a $0.45 \mathrm{~mm}$ sieve screen (Figure 5.3). A $0.075 \mathrm{~mm}$ sieve screen was also placed horizontally above the filter paper to further prevent any non dust particles from settling onto the filter paper (Figure 5.4). The filter box was placed on the bumper so that its centerline would align horizontally with the center of the driver's side rear tire. 


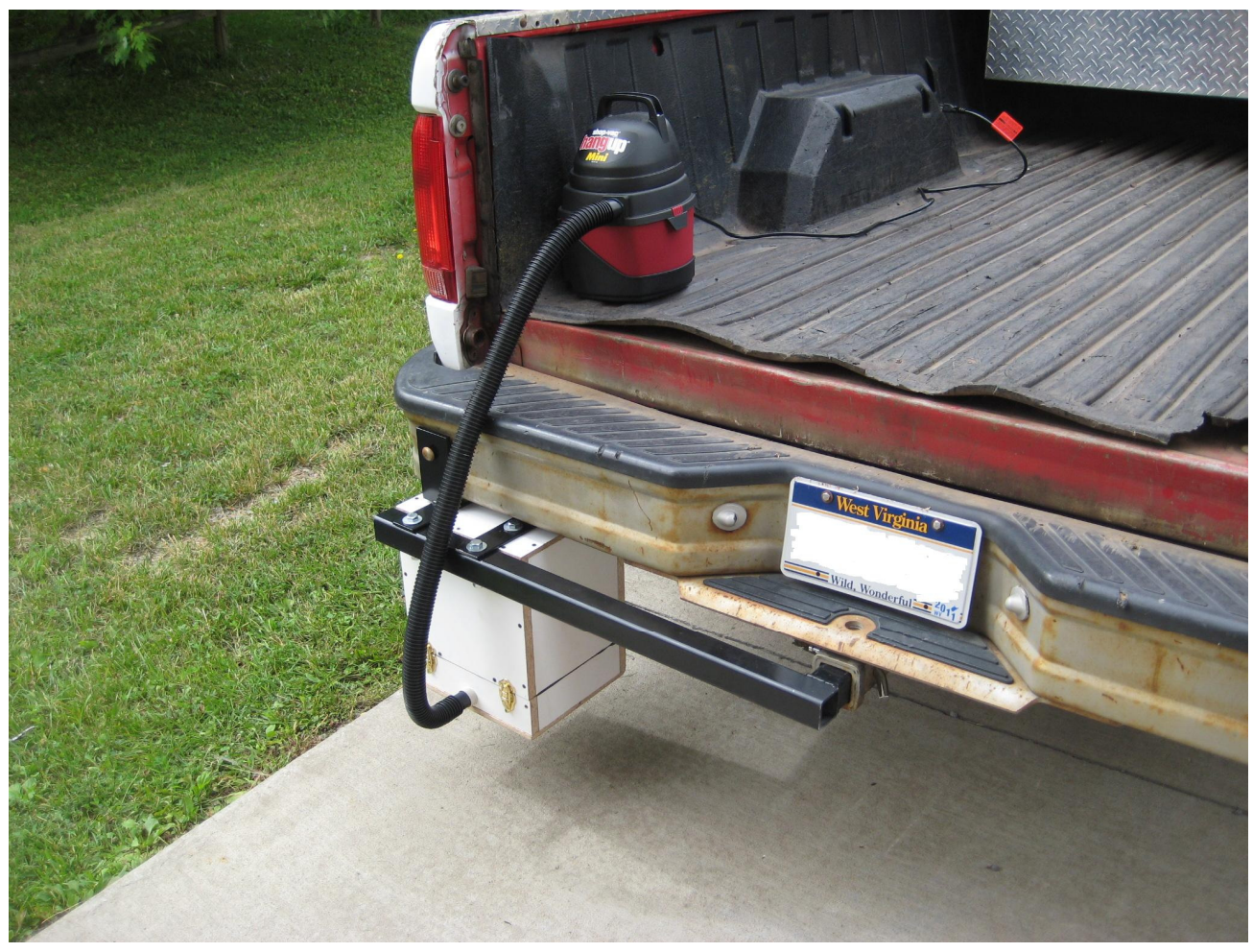

Figure 5.2 Rear View of Dust Collector Mounted to Bumper of Test Vehicle

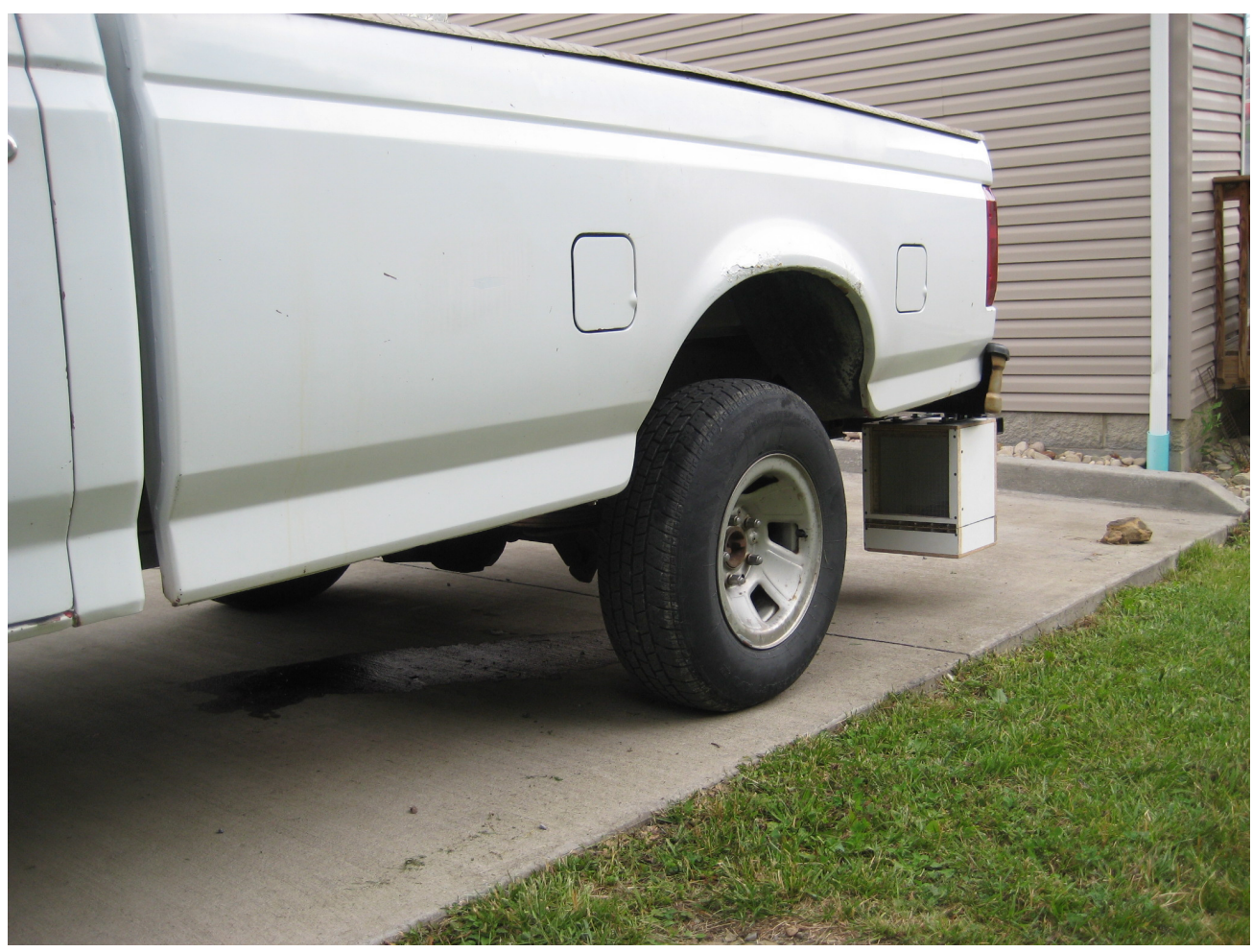

Figure 5.3 Opening of Filter Box Facing the Rear Wheel of Test Vehicle 


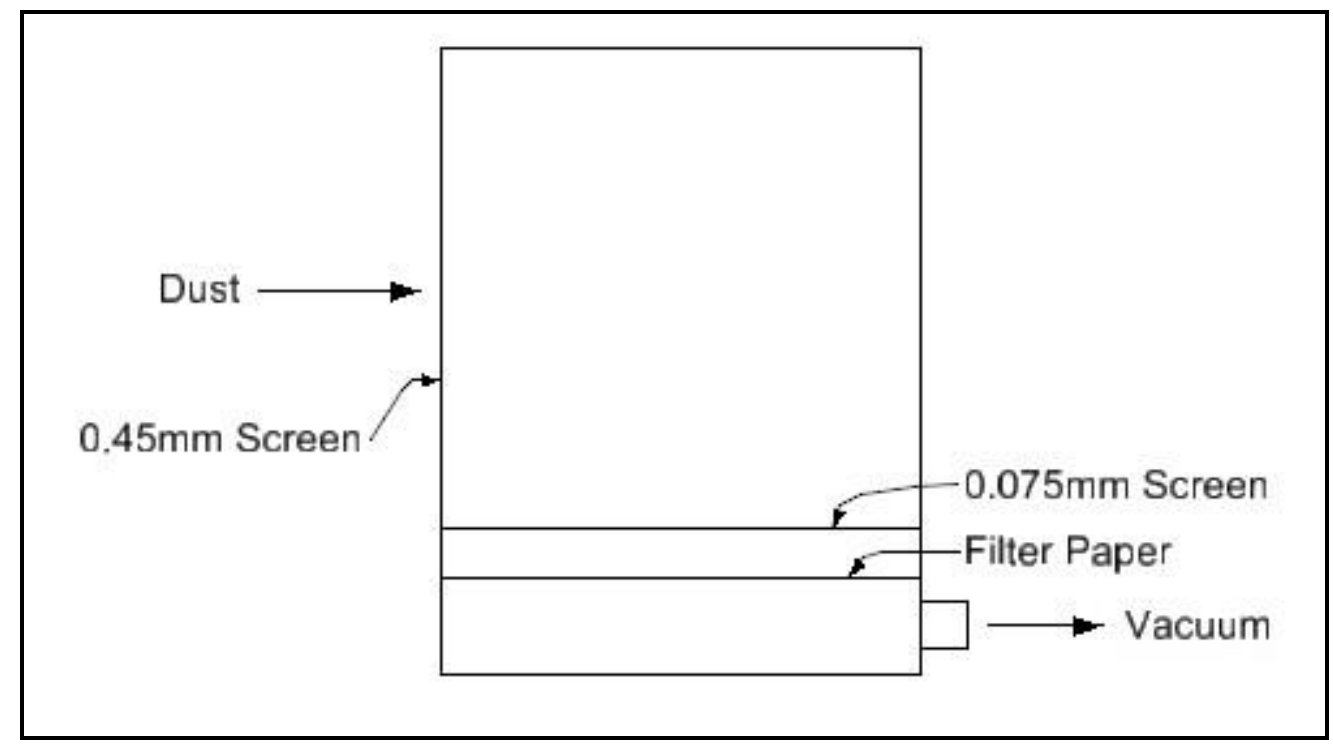

Figure 5.4 Cross Sectional View of Dust Collector

Preparation of the vehicle and dust collector for data collection involved:

1. The dust collector was assembled and attached to the test vehicle as shown in Figure 5.2.

2. A pre-weighed glass fiber filter paper was then inserted into the filter box.

3. The flexible hose was connected to the vacuum pump and filter box, the vacuum's power cord was connected to the switchbox, the switchbox was plugged into the power inverter

4. Both the vacuum and power inverter were switched to the "ON" position with the switchbox remaining in the "OFF" position.

Having a switchbox in the cab of the vehicle enabled the filter box to be powered on by the operator after reaching a constant speed. The test vehicle was positioned at the start of a 180 $\mathrm{ft}$ transition area then accelerated to $25 \mathrm{mph}$. A speed of $25 \mathrm{mph}$ was chosen because it was the fastest speed that could be safely maintained on all the test sections. Upon reaching the start of a test section, the switchbox was placed in the "ON" position. Then, upon reaching the end of the 
test section, the switchbox was placed in the "OFF" position. In order to capture a measurable amount of dust, Sanders (personal communication, June 22, 2010) recommended using test sections each one mile in length. The test sections in this experiment were one quarter mile so four passes, two in each direction, were treated as a single run. The dust generated by the test vehicle was captured by the filter box and deposited onto the glass fiber filter paper. After each run, the dust-laden filter paper was removed and placed into a pre-weighed plastic storage bag to be later taken to the laboratory for gravimetric analysis. This procedure was repeated three times for each section. The sequence of runs was randomized to prevent bias in the testing. Bias could develop from variables such as changes in temperature, dew point, humidity, and relative amounts of shaded areas which occur throughout the cycle of a day. Furthermore, in an attempt to produce reliable data, all testing procedures, as well as the test vehicle, speed, and operator remained constant throughout the evaluation period.

\subsection{SAMPLING SURFACE/BULK DUST LOADING}

In addition to performing dust collection with the mobile dust sampler, soil samples were collected to analyze the moisture contents (in percent) and silt fractions (in $\mathrm{g} / \mathrm{m}^{2}$ ) for each section. Procedures for sampling were followed according to Appendix C.1 of EPA AP-42 document (U.S. EPA, 1995). Figure 5.5 shows a surface/bulk dust loading sample being collected on section 7 (bituminous resin pitch, “TechSuppress") three days after product application. The importance of using this type of analysis in conjunction with dust collection was displayed by Johnson and Olson (2009). 


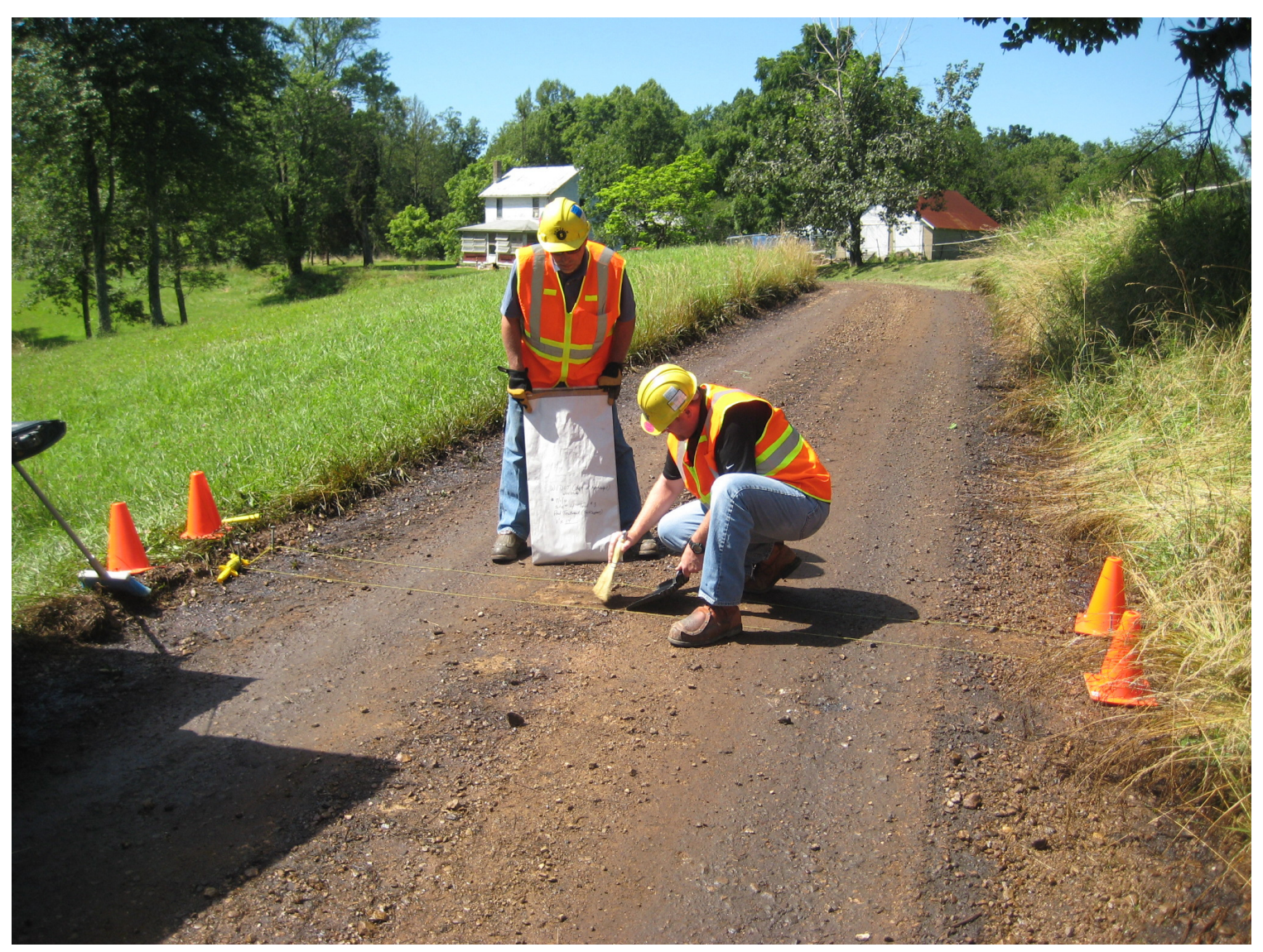

Figure 5.5 Collection of a Surface/Bulk Dust Loading Sample

Soil samples were collected within one day of dust collection, as shown in the log of activities, Appendix C. Since precipitation largely impacts the moisture content of soils, samples were not obtained in wet conditions. Three samples were collected for each test section to provide a sufficient amount of data for statistical analysis, resulting in a total of 27 soil samples for each day of data collection. This sampling took a short time period which limited the potential for bias due to weather conditions so it was not necessary to randomize the sequence of sample collections.

\subsection{DATA COLLECTION SCHEDULE}

The research plan specified data collection at 7, 14, 30, 60, and 90 days following product applications. However, problems with the power supply for the dust collector caused 
data collection to begin at 8 days following product applications. The next three data collection days were approximately on schedule, taking place at 15, 28, and 61 days following product applications. Due to rain, the final data collection day took place at 103 days following product applications. Therefore, data was collected at 8, 15, 28, 61, and 103 days following product applications. Since products were placed within three consecutive days the data collection sequence was not offset for each section.

\subsection{WEATHER MEASUREMENTS}

Table 5.1 shows the consecutive number of dry days, or days without rain, immediately before each day of data collection. A rain event was considered to be any precipitation reading greater than 0.01 inches. A log of activities and weather conditions during the product evaluation period are presented in Appendices C and D, respectively. Figure 5.6 also shows weather observations, including precipitation (scaled to fit chart area), relative humidity (\%), and maximum and minimum temperatures $\left({ }^{\circ} \mathrm{F}\right)$ over the evaluation period. Weather conditions were obtained from readings taken at the Mid Ohio Valley Regional Airport located in Parkersburg, $\mathrm{WV}$, approximately ten miles from the test route.

Table 5.1 Number of Consecutive Dry Days before Each Day of Data Collection

\begin{tabular}{|c|c|}
\hline Data Collection Day & $\begin{array}{c}\text { Number of Dry Days Prior to } \\
\text { Measurement }\end{array}$ \\
\hline 8 & 5 \\
\hline 15 & 1 \\
\hline 28 & 2 \\
\hline 61 & 8 \\
\hline 103 & 5 \\
\hline
\end{tabular}




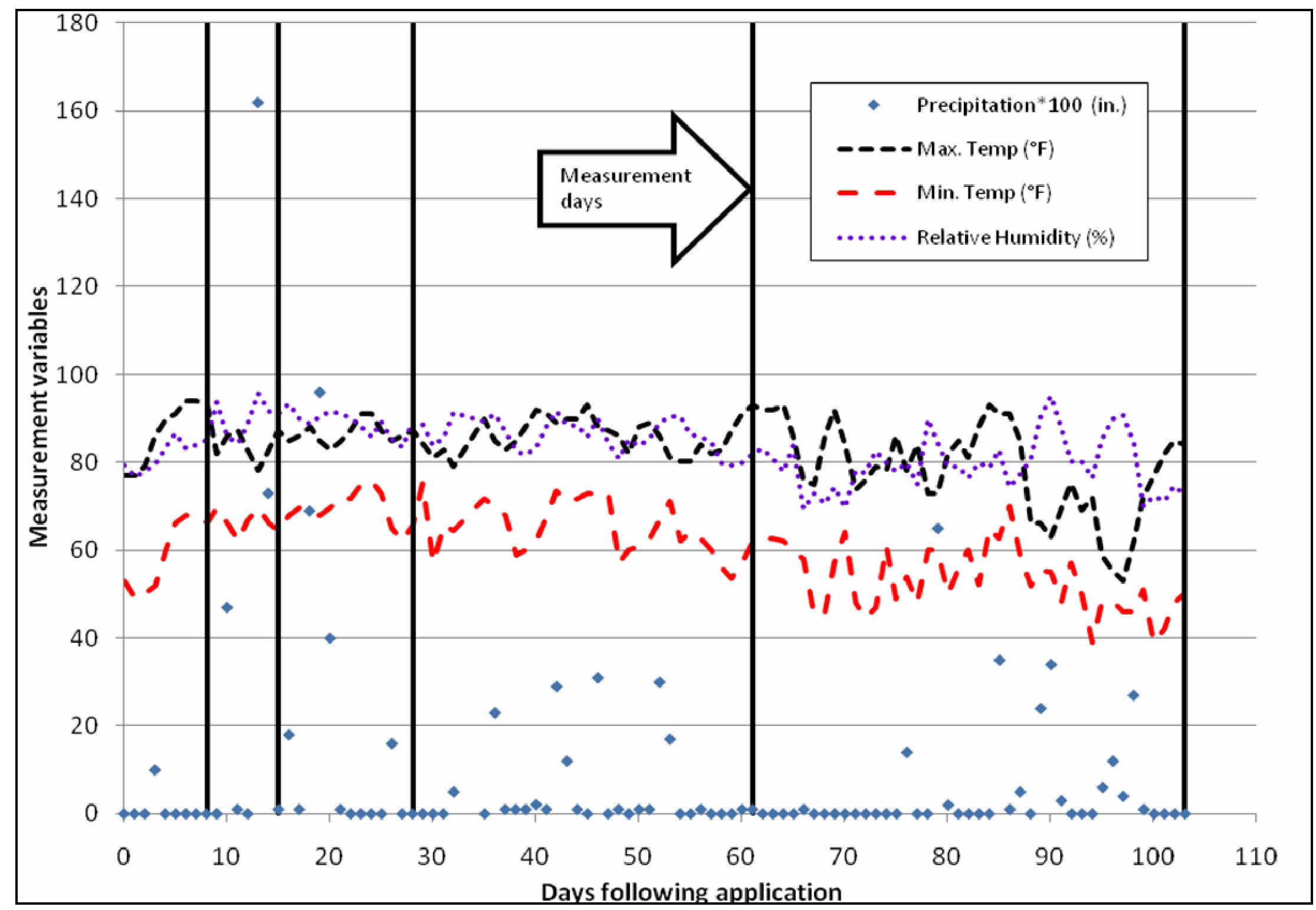

Figure 5.6 Weather Observations throughout Observation Period 


\section{CHAPTER 6 RESULTS AND ANALYSIS}

The Statistical Analysis Software, SAS JMP 9, was used for statistical analysis. The dust measurements, soil silt fractions, soil moisture contents, and $\mathrm{PM}_{10}$ emissions estimates using the EPA AP-42 equation were analyzed as separate data sets. The same approach was used to analyze all four data sets.

First, the data for each day was input into SAS JMP. Then, results of data collected on treated sections were compared to that of the untreated controls for each day. Summary statistics told much about the general fit of each data set and one-way analysis of variance (ANOVA) provided conclusions as to whether the group means were statistically the same. The ANOVA did not tell which means differed from each other. The Tukey-Kramer HSD (honestly significant difference) test was used to provide insight into comparing means within data sets. A 95\% confidence level $(\alpha=0.05)$ was used throughout the analysis. The complete data sets are provided in Appendices E, F, G, and H. Table 6.1 shows a summary of the dust measurements, soil silt fractions, soil moisture contents, and $\mathrm{PM}_{10}$ emissions estimates using the EPA AP-42 equation. 


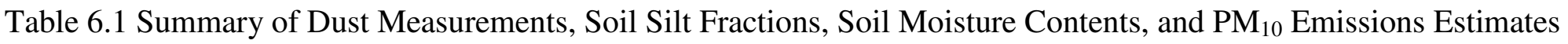

\begin{tabular}{|c|c|c|c|c|c|c|c|c|c|c|c|c|c|c|c|c|c|c|c|}
\hline \multirow[t]{2}{*}{ DAY } & \multirow[t]{2}{*}{ DATA } & \multicolumn{2}{|c|}{$\begin{array}{c}1 \\
\text { Petrotac }\end{array}$} & \multicolumn{2}{|c|}{$\begin{array}{c}2 \\
\text { Untreated } 1\end{array}$} & \multicolumn{2}{|c|}{$\begin{array}{c}3 \\
\text { EK35 }\end{array}$} & \multicolumn{2}{|c|}{$\begin{array}{c}4 \\
\text { Untreated } 2\end{array}$} & \multicolumn{2}{|c|}{$\begin{array}{c}5 \\
\text { Calcium } \\
\text { Chloride }\end{array}$} & \multicolumn{2}{|c|}{$\begin{array}{c}6 \\
\text { Untreated } 3\end{array}$} & \multicolumn{2}{|c|}{$\begin{array}{c}7 \\
\text { Tech } \\
\text { Suppress }\end{array}$} & \multicolumn{2}{|c|}{$\begin{array}{c}8 \\
\text { Untreated } 4\end{array}$} & \multicolumn{2}{|c|}{$\begin{array}{c}9 \\
\text { Dust } \\
\text { Fyghter }\end{array}$} \\
\hline & & $\bar{x}$ & $s$ & $\bar{x}$ & $\mathrm{~s}$ & $\bar{x}$ & $\mathrm{~s}$ & $\bar{x}$ & $\mathrm{~s}$ & $\bar{x}$ & $\mathrm{~s}$ & $\bar{x}$ & $\mathrm{~s}$ & $\bar{x}$ & $\mathrm{~s}$ & $\bar{x}$ & $\mathrm{~s}$ & $\bar{x}$ & $\mathrm{~s}$ \\
\hline \multirow{3}{*}{8} & Silt Fraction $\left(\mathrm{g} / \mathrm{m}^{2}\right)$ & - & - & - & - & - & - & - & - & - & - & - & - & - & - & - & - & - & - \\
\hline & Moisture Content (\%) & 0.310 & 0.173 & 0.187 & 0.089 & 0.433 & 0.051 & 0.340 & 0.036 & 1.687 & 0.176 & 0.547 & 0.127 & 0.850 & 0.331 & 0.293 & 0.021 & 0.223 & 0.059 \\
\hline & Est. $\mathrm{PM}_{10}(\mathrm{lb} / \mathrm{VMT})$ & 0.063 & 0.051 & 0.750 & 0.350 & 0.230 & 0.010 & 0.683 & 0.143 & 0.237 & 0.110 & 0.770 & 0.114 & 0.077 & 0.021 & 1.127 & 0.140 & 0.067 & 0.032 \\
\hline \multirow{3}{*}{15} & Mass of Dust (g/mile) & 0.090 & 0.082 & 0.243 & 0.021 & 0.340 & 0.036 & 0.350 & 0.060 & 0.210 & 0.010 & 0.180 & 0.056 & 0.150 & 0.026 & 0.457 & 0.031 & 0.187 & 0.012 \\
\hline & Silt Fraction $\left(g / \mathrm{m}^{2}\right)$ & - & - & - & - & - & - & - & - & - & - & - & - & - & - & - & - & - & - \\
\hline & Est. $\mathrm{PM}_{10}(\mathrm{lb} / \mathrm{VMT})$ & - & - & - & - & - & - & - & - & - & - & - & - & - & - & - & - & - & - \\
\hline \multirow{4}{*}{28} & Mass of Dust (g/mile) & 0.083 & 0.035 & 0.700 & 0.131 & 0.767 & 0.058 & 0.787 & 0.086 & 0.423 & 0.068 & 0.800 & 0.085 & 0.367 & 0.107 & 1.390 & 0.182 & 0.497 & 0.032 \\
\hline & Silt Fraction $\left(\mathrm{g} / \mathrm{m}^{2}\right)$ & 3.13 & 1.17 & 278.81 & 109.00 & 326.75 & 137.82 & 176.41 & 45.70 & 111.22 & 36.42 & 238.86 & 34.05 & 42.40 & 21.30 & 423.00 & 90.45 & 46.72 & 12.54 \\
\hline & Moisture Content (\%) & 0.580 & 0.452 & 0.420 & 0.096 & 0.360 & 0.030 & 0.307 & 0.046 & 0.863 & 0.106 & 0.390 & 0.078 & 0.463 & 0.206 & 0.170 & 0.020 & 0.163 & 0.032 \\
\hline & Est. $\mathrm{PM}_{10}(\mathrm{lb} / \mathrm{VMT})$ & 0.130 & 0.061 & 0.880 & 0.114 & 0.930 & 0.027 & 0.927 & 0.042 & 0.547 & 0.112 & 1.243 & 0.061 & 15.607 & 26.321 & 1.213 & 0.351 & 0.453 & 0.103 \\
\hline \multirow{4}{*}{61} & Mass of Dust (g/mile) & 0.217 & 0.025 & 1.180 & 0.296 & 1.140 & 0.090 & 1.220 & 0.161 & 1.053 & 0.107 & 1.243 & 0.117 & 0.957 & 0.285 & 1.613 & 0.189 & 0.903 & 0.196 \\
\hline & Silt Fraction $\left(\mathrm{g} / \mathrm{m}^{2}\right)$ & 6.93 & 3.91 & 571.35 & 317.47 & 607.28 & 172.86 & 624.10 & 74.80 & 303.28 & 58.91 & 861.62 & 458.33 & 778.61 & 436.56 & 714.25 & 44.50 & 99.42 & 89.77 \\
\hline & Moisture Content (\%) & 0.370 & 0.137 & 0.743 & 0.383 & 0.563 & 0.078 & 0.350 & 0.061 & 0.947 & 0.119 & 0.850 & 0.532 & 0.337 & 0.144 & 0.137 & 0.021 & 0.160 & 0.030 \\
\hline & Est. $\mathrm{PM}_{10}(\mathrm{lb} / \mathrm{VMT})$ & 0.253 & 0.093 & 1.773 & 0.144 & 1.460 & 0.131 & 1.903 & 0.124 & 1.247 & 0.146 & 2.040 & 0.405 & 1.753 & 0.201 & 2.083 & 0.132 & 0.937 & 0.317 \\
\hline \multirow{3}{*}{103} & Mass of Dust (g/mile) & 0.127 & 0.006 & 0.343 & 0.035 & 0.550 & 0.111 & 0.517 & 0.057 & 0.370 & 0.010 & 0.407 & 0.015 & 0.443 & 0.042 & 0.517 & 0.237 & 0.337 & 0.035 \\
\hline & Silt Fraction $\left(\mathrm{g} / \mathrm{m}^{2}\right)$ & 55.35 & 20.71 & 33.66 & 10.20 & 158.47 & 78.86 & 172.94 & 72.26 & 84.05 & 22.26 & 111.35 & 25.86 & 212.04 & 15.56 & 411.30 & 62.06 & 88.57 & 52.67 \\
\hline & Moisture Content (\%) & 0.500 & 0.161 & 0.383 & 0.101 & 0.547 & 0.111 & 0.797 & 0.115 & 1.073 & 0.100 & 2.397 & 0.458 & 0.453 & 0.031 & 0.297 & 0.099 & 0.560 & 0.184 \\
\hline
\end{tabular}

$\bar{x}=$ sample mean

$\mathrm{s}=$ sample std. deviation 


\subsection{DUST MEASUREMENT DATA}

The dust collection procedure was performed on the test route at $8,15,28,61$, and 103 days following product applications. Raw data obtained from the dust collection procedure is presented in Appendix E. A portion of the data for the Day-8 dust measurement was not obtained due to a malfunction with the mobile dust sampler. Each data set includes summary statistics, ANOVA tables, and Tukey-Kramer reports for each day of collected data. The statistical results from each day of measurement are presented individually in sections 6.1.1 through 6.1.5. A summary of all data is presented in section 6.1.6.

\subsubsection{Day-8 Analysis}

Figure 6.1 shows the summary of fit for Day- 8 data. A coefficient of determination $\left(\mathrm{R}^{2}\right)$ of 0.963 indicates a strong positive association between treatment type and amount of dust generated. The one way ANOVA results, Figure 6.2, indicate strong evidence $(\mathrm{P}<0.0001)$ against the null hypothesis that the population means are equal. Therefore, it can be said that the means of groups are significantly different.

\begin{tabular}{|lr|}
\hline Summary of Fit \\
Rsquare & 0.963051 \\
Adj Rsquare & 0.940313 \\
Root Mean Square Error & 0.128577 \\
Mean of Response & 0.577727 \\
Observations (or Sum Wgts) & 22 \\
\hline
\end{tabular}

Figure 6.1 Summary of Fit for Day-8 Dust Collection Data

\begin{tabular}{|lrrrrr|}
\hline \multicolumn{7}{|l|}{ Analysis of Variance } \\
Source & DF & $\begin{array}{r}\text { Sum of } \\
\text { Squares }\end{array}$ & Mean Square & F Ratio & Prob > F \\
Treat & 8 & 5.6016697 & 0.700209 & 42.3546 & $<.0001^{\star}$ \\
Error & 13 & 0.2149167 & 0.016532 & & \\
C. Total & 21 & 5.8165864 & & & \\
\hline
\end{tabular}

Figure 6.2 ANOVA Table for Day-8 Dust Collection Data 
Figure 6.3 displays the connecting letter report for the Tukey-Kramer multiple comparison method. Results indicate that Untreated 4 is statistically different than the other three untreated control sections and that all five dust control products are different from the untreated controls. There is no difference in the mean levels of dust generated by Untreated 1, Untreated 2, and Untreated 3; all of these have letter "B." The results also indicate that there is no difference in the mean levels dust generated on the sections treated with dust control products; all of these have letter "C." All sections chemically treated with dust control agents produced less dust than the untreated control sections.

\begin{tabular}{|lrrr|}
\hline Level & & & \multicolumn{1}{c|}{ Mean } \\
Untreated 4 & A & & 1.5400000 \\
Untreated 2 & B & 1.0000000 \\
Untreated 3 & B & 0.9600000 \\
Untreated 1 & B & 0.8500000 \\
EK35 & C & 0.2633333 \\
Calcium Chloride & C & 0.2600000 \\
Tech Suppress & C & 0.2000000 \\
Dust Fyghter & C & 0.1100000 \\
Petrotac & C & 0.0850000 \\
Levels not connected by same letter are significantly different. & \\
\hline
\end{tabular}

Figure 6.3 Tukey-Kramer Connecting Letter Report for Day-8 Dust Collection Data

\subsubsection{Day-15 Analysis}

Figure 6.4 shows the summary of fit for Day-15 data. A coefficient of determination $\left(\mathrm{R}^{2}\right)$ of 0.904 indicates a strong positive association between treatment type and amount of dust generated. The one way ANOVA results, Figure 6.5, indicate strong evidence $(\mathrm{P}<0.0001)$ against the null hypothesis that the population means are equal. Therefore, it can be said that the means of groups are significantly different. 


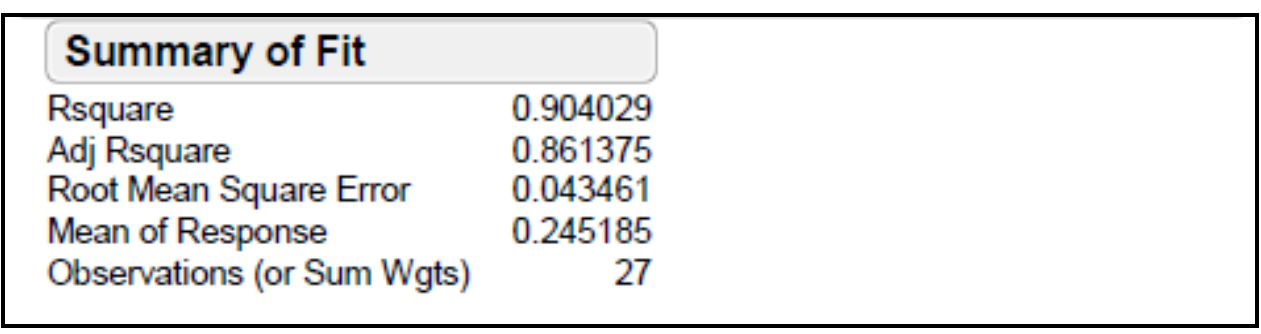

Figure 6.4 Summary of Fit for Day-15 Dust Collection Data

\begin{tabular}{|lrrrrr|}
\hline \multicolumn{6}{|l|}{ Analysis of Variance } \\
Source & DF & $\begin{array}{r}\text { Sum of } \\
\text { Squares }\end{array}$ & Mean Square & F Ratio & Prob $>$ F \\
Treat & 8 & 0.32027407 & 0.040034 & 21.1946 & $<.0001^{\star}$ \\
Error & 18 & 0.0340000 & 0.001889 & & \\
C. Total & 26 & 0.35427407 & & & \\
\hline
\end{tabular}

Figure 6.5 ANOVA Table for Day-15 Dust Collection Data

Figure 6.6 displays the connecting letter report for the Tukey-Kramer multiple comparison method. There are no significant differences among the mean levels of dust generated by Petrotac, Tech Suppress, Untreated 3, Dust Fyghter, and Calcium Chloride; all of these have letter "D." It seems that EK35 has no effect on dust control because its mean is similar to the untreated surfaces. No significant differences are found among Untreated 2, Untreated 1, and EK35; all of these have letter "B." There are no significant differences among Untreated 4, Untreated 2, and EK35; all of these have letter "A."

\begin{tabular}{|lll|}
\hline Level & & \multicolumn{1}{c|}{ Mean } \\
Untreated 4 & A & 0.45666667 \\
Untreated 2 & A B & 0.35000000 \\
EK35 & A B & 0.34000000 \\
Untreated 1 & B C & 0.24333333 \\
Calcium Chloride & C D & 0.21000000 \\
Dust Fyghter & C D & 0.18666667 \\
Untreated 3 & C D & 0.18000000 \\
Tech Suppress & C D & 0.15000000 \\
Petrotac & D & 0.09000000 \\
Levels not connected by same letter are significantly different. & \\
\hline
\end{tabular}

Figure 6.6 Tukey-Kramer Connecting Letter Report for Day-15 Dust Collection Data 


\subsubsection{Day-28 Analysis}

Figure 6.7 shows the summary of fit for Day-28 data. A coefficient of determination $\left(\mathrm{R}^{2}\right)$ of 0.949 indicates a strong positive association between treatment type and amount of dust generated. The one way ANOVA results, Figure 6.8, indicate strong evidence $(\mathrm{P}<0.0001)$ against the null hypothesis that the population means are equal. Therefore, it can be said that the means of groups are significantly different.

\begin{tabular}{|lr|}
\hline Summary of Fit & \\
Rsquare & 0.949134 \\
Adj Rsquare & 0.926528 \\
Root Mean Square Error & 0.098263 \\
Mean of Response & 0.645926 \\
Observations (or Sum Wgts) & 27 \\
\hline
\end{tabular}

Figure 6.7 Summary of Fit for Day-28 Dust Collection Data

\begin{tabular}{|c|c|c|c|c|c|}
\hline \multicolumn{6}{|c|}{ Analysis of Variance } \\
\hline Source & DF & $\begin{array}{r}\text { Sum of } \\
\text { Squares }\end{array}$ & Mean Square & F Ratio & Prob $>$ F \\
\hline Treat & 8 & 3.2430519 & 0.405381 & 41.9843 & $<.0001^{\star}$ \\
\hline Error & 18 & 0.1738000 & 0.009656 & & \\
\hline C. Total & 26 & 3.4168519 & & & \\
\hline
\end{tabular}

Figure 6.8 ANOVA Table for Day-28 Dust Collection Data

Figure 6.9 displays the connecting letter report for the Tukey-Kramer multiple comparison method. The mean level of dust generated on the section treated with Petrotac is significantly less than all other sections, as denoted by letter "F." There are no significant differences among the mean levels of dust generated by Tech Suppress, Calcium Chloride, and Dust Fyghter; all of these have letter "E." There are no significant differences among the mean levels of dust generated by Calcium Chloride, Dust Fyghter, and Untreated 1; all of these have letter "D." There are no significant differences among the mean levels of dust generated by Dust Fyghter, Untreated 1, and EK35; all of these have letter "C." No significant differences are found among the mean levels of dust generated by Untreated 1, EK35, Untreated 2, and 
Untreated 3; all of these have letter "B." Untreated 4 produced mean levels of dust significantly higher than all other sections.

\begin{tabular}{|lrr|r|}
\hline Level & \multicolumn{1}{c|}{ Mean } \\
Untreated 4 & A & 1.3900000 \\
Untreated 3 & B & 0.8000000 \\
Untreated 2 & B & 0.7866667 \\
EK35 & B C & 0.7666667 \\
Untreated 1 & B C D & 0.7000000 \\
Dust Fyghter & C D E & 0.4966667 \\
Calcium Chloride & D E & 0.4233333 \\
Tech Suppress & \multicolumn{2}{c}{ E } & 0.3666667 \\
Petrotac & \multicolumn{2}{c}{ F } & 0.0833333 \\
Levels not connected by same letter are significantly different. \\
\hline
\end{tabular}

Figure 6.9 Tukey-Kramer Connecting Letter Report for Day-28 Dust Collection Data

\subsubsection{Day-61 Analysis}

Figure 6.10 shows the summary of fit for Day-61 data. A coefficient of determination $\left(\mathrm{R}^{2}\right)$ of 0.849 indicates a positive association between treatment type and amount of dust generated. The one way ANOVA results, Figure 6.11, indicate strong evidence $(\mathrm{P}<0.0001)$ against the null hypothesis that the population means are equal. Therefore, it can be said that the means of groups are significantly different.

\begin{tabular}{|lr|}
\hline Summary of Fit & \\
Rsquare & 0.848607 \\
Adj Rsquare & 0.781321 \\
Root Mean Square Error & 0.183515 \\
Mean of Response & 1.058519 \\
Observations (or Sum Wgts) & 27 \\
\hline
\end{tabular}

Figure 6.10 Summary of Fit for Day-61 Dust Collection Data

\begin{tabular}{|c|c|c|c|c|c|}
\hline \multicolumn{6}{|c|}{ Analysis of Variance } \\
\hline Source & DF & $\begin{array}{l}\text { Sum of } \\
\text { Squares }\end{array}$ & Mean Square & F Ratio & Prob $>$ F \\
\hline Treat & 8 & 3.3979407 & 0.424743 & 12.6120 & $<.0001^{*}$ \\
\hline Error & 18 & 0.6062000 & 0.033678 & & \\
\hline C. Total & 26 & 4.0041407 & & & \\
\hline
\end{tabular}

Figure 6.11 ANOVA Table for Day-61 Dust Collection Data 
Figure 6.12 displays the connecting letter report for the Tukey-Kramer multiple comparison method. The mean level of dust generated on the section treated with Petrotac is significantly less than all other sections, as denoted by letter "C." There are no significant differences among the mean levels of dust generated by Dust Fyghter, Tech Suppress, Calcium Chloride, EK35, Untreated 1, Untreated 2, and Untreated 3; all of these have letter "B." No significant differences were found among the means levels of dust generated by EK35 and the untreated control sections; all of these have letter "A."

\begin{tabular}{|c|c|c|}
\hline Level & & Mean \\
\hline Untreated 4 & A & 1.6133333 \\
\hline Untreated 3 & $A B$ & 1.2433333 \\
\hline Untreated 2 & $A B$ & 1.2200000 \\
\hline Untreated 1 & $A B$ & 1.1800000 \\
\hline EK35 & $A B$ & 1.1400000 \\
\hline Calcium Chloride & B & 1.0533333 \\
\hline Tech Suppress & B & 0.9566667 \\
\hline Dust Fyghter & B & 0.9033333 \\
\hline Petrotac & C & 0.2166667 \\
\hline
\end{tabular}

Figure 6.12 Tukey-Kramer Connecting Letter Report for Day-61 Dust Collection Data

\subsubsection{Day-103 Analysis}

Figure 6.13 shows the summary of fit for Day-103 data. A coefficient of determination $\left(\mathrm{R}^{2}\right)$ of 0.725 indicates a positive association between treatment type and amount of dust generated. The one way ANOVA results, Figure 6.14, indicate strong evidence $(\mathrm{P}<0.0008)$ against the null hypothesis that the population means are equal. Therefore, it can be said that the means of groups are significantly different.

\begin{tabular}{|lr|}
\hline Summary of Fit & \\
Rsquare & 0.725192 \\
Adj Rsquare & 0.603055 \\
Root Mean Square Error & 0.092155 \\
Mean of Response & 0.401111 \\
Observations (or Sum Wgts) & 27 \\
\hline
\end{tabular}

Figure 6.13 Summary of Fit for Day-103 Dust Collection Data 


\begin{tabular}{|lrrrrr|}
\hline \multicolumn{5}{|l|}{ Analysis of Variance } \\
Source & DF & Sum of & & & \\
Squares & Mean Square & F Ratio & Prob > F \\
Treat & 8 & 0.40340000 & 0.050425 & 5.9375 & $0.0008^{*}$ \\
Error & 18 & 0.15286667 & 0.008493 & & \\
C. Total & 26 & 0.55626667 & & & \\
\hline
\end{tabular}

Figure 6.14 ANOVA Table for Day-103 Dust Collection Data

Figure 6.15 displays the connecting letter report for the Tukey-Kramer multiple comparison method. There are no significant differences among the mean levels of dust generated by Petrotac, Dust Fyghter, Untreated 1, and Calcium Chloride; all of these have letter "B."

\begin{tabular}{|llr|}
\hline Level & & Mean \\
EK35 & A & 0.55000000 \\
Untreated 4 & A & 0.51666667 \\
Untreated 2 & A & 0.51666667 \\
Tech Suppress & A & 0.44333333 \\
Untreated 3 & A & 0.40666667 \\
Calcium Chloride A B & 0.37000000 \\
Untreated 1 & A B & 0.34333333 \\
Dust Fyghter & A B & 0.33666667 \\
Petrotac & B & 0.12666667 \\
Levels not connected by same letter are significantly different. \\
\hline
\end{tabular}

Figure 6.15 Tukey-Kramer Connecting Letter Report for Day-103 Dust Collection Data

\subsubsection{Comparison of Dust Measurements across Time}

Figures 6.16 and 6.17 are graphs which summarize all dust measurements (in grams/mile) over the evaluation period. At Day-8, all sections treated with dust control products showed no significant differences among the mean levels of dust; all produced less dust than the untreated control sections. At Day-15, there were no significant differences among the mean levels of dust on sections treated with Petrotac, Tech Suppress, Dust Fyghter, and Calcium Chloride, and Untreated 3. The section treated with EK 35 produced mean levels of dust comparable to the untreated control sections in as little as 15 days. At Day-28, the mean level of dust on the 
section treated with Petrotac was significantly less than all other sections. At Day-61, the mean level of dust on the section treated with Petrotac was significantly less than all other sections. At Day-103, there were no significant differences among the mean levels of dust on sections treated with Petrotac, Dust Fyghter, Calcium Chloride, and Untreated 1.

The surface of Untreated 4 was exposed to more sunlight, i.e. fewer trees shading the road surface, than the other sections. The Tukey-Kramer analyses revealed that Untreated 4 had significantly higher dust levels than the other sections for four of the five measurement cycles. This observation supports the hypothesis that sunlight evaporated moisture from the surface and the drier surface allowed greater dust generation by a vehicle pass.

It is also apparent from Figure 5.6 that rain influenced the amount of dust measured throughout the evaluation period. Dust measurements which took place on Day-15 show much less dust generation for all sections. This collection day coincided with a substantial rainfall event one day prior to measurement. Day-28 also coincided with a rainfall event two days prior to measurement; however the low rainfall intensity had little effect on the dust measurements for this day. 


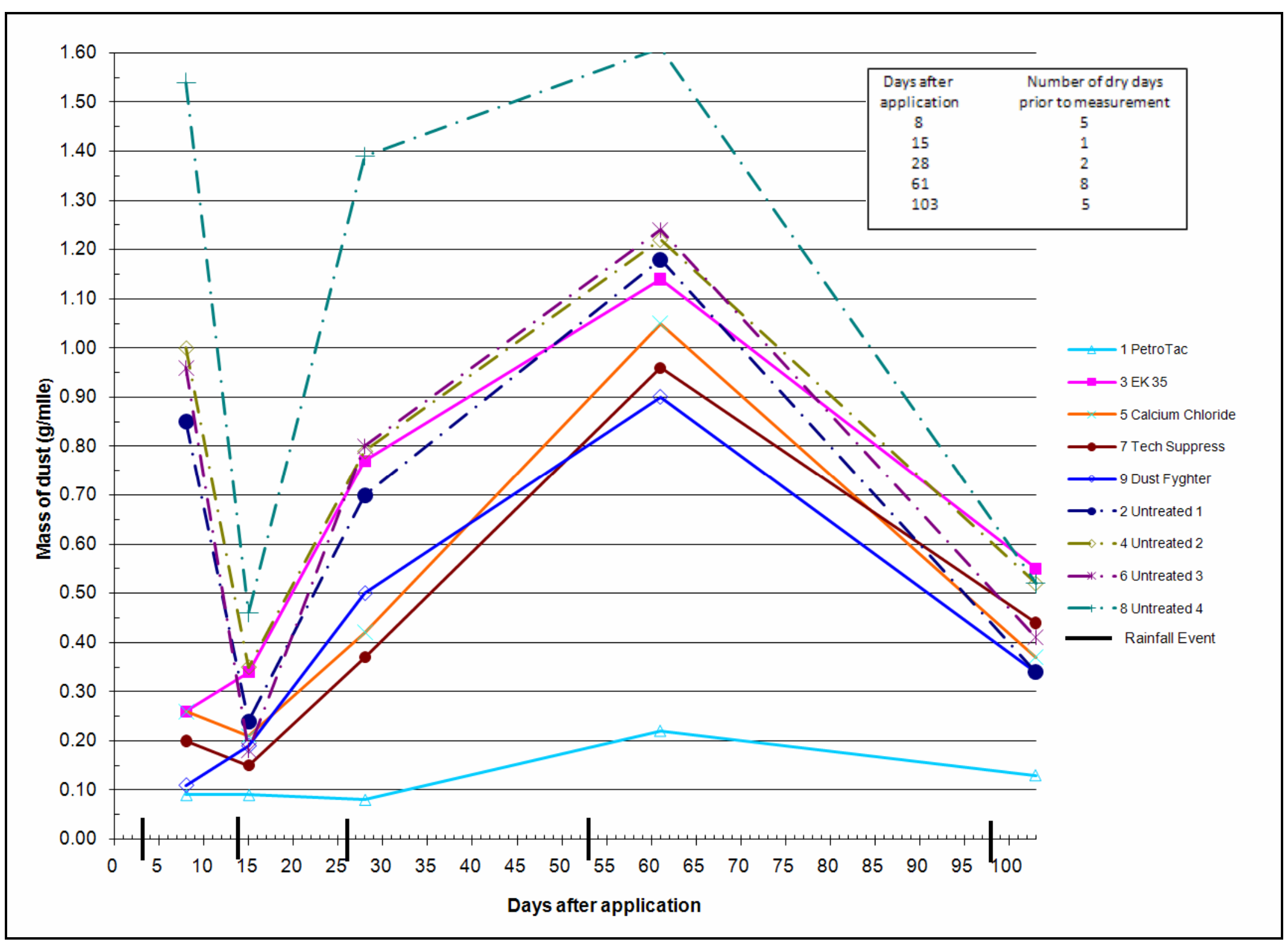

Figure 6.16 Trends of Dust Measurements across Time 


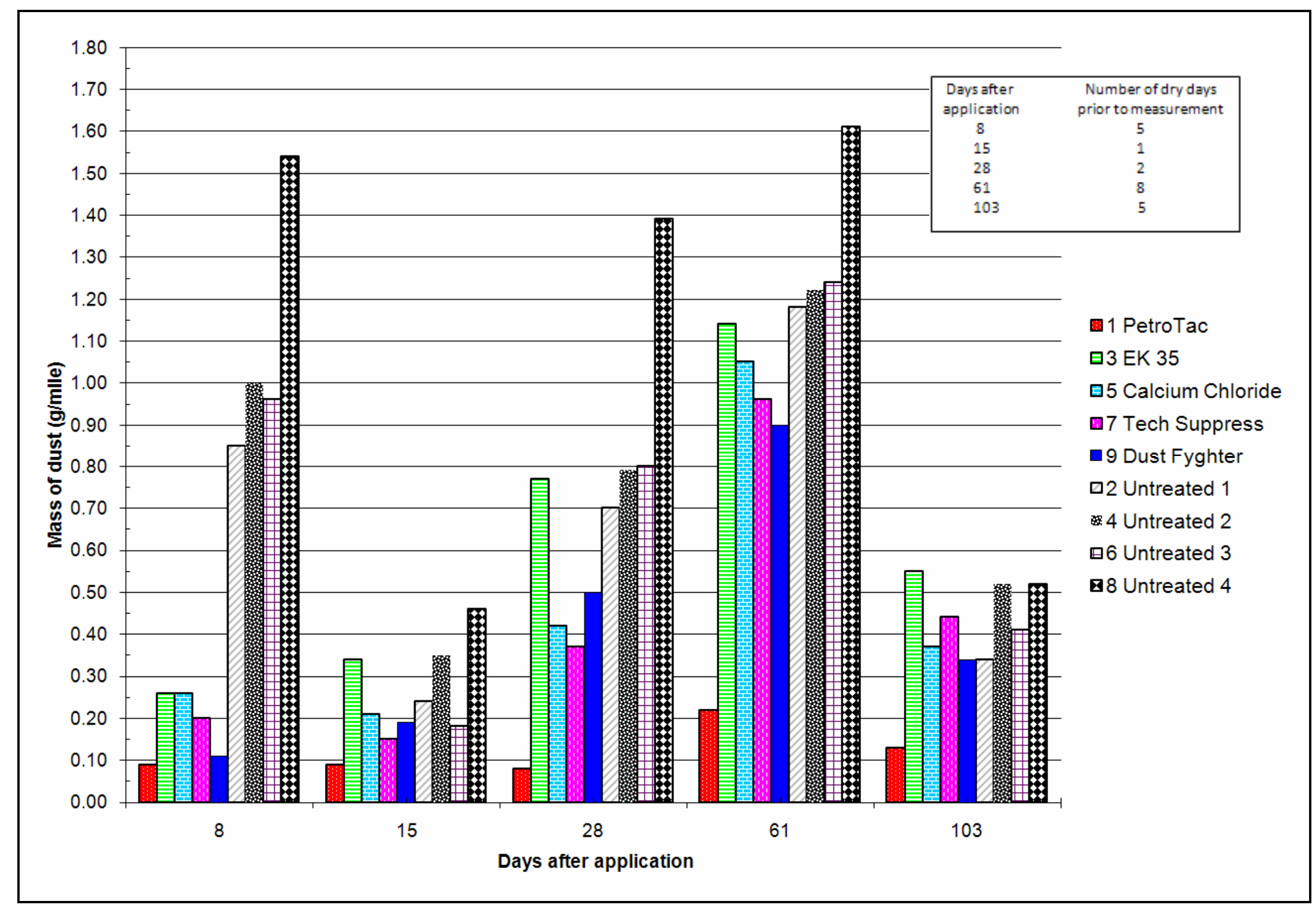

Figure 6.17 Bar Chart Summarizing Dust Measurements across Time 


\subsection{SOIL SILT FRACTIONS}

Raw data obtained for silt load sampling is presented in Appendix F. Soil silt fraction samples were collected for Day-8. However, the area over which the samples were collected was not measured, so the silt load, in $\mathrm{g} / \mathrm{m}^{2}$, could not be computed. Hence, the data from Day- 8 are not included in the following analysis. Soil samples for Day-15 were not collected as rainfall following the collection of the dust measurements meant an analysis of soil silt fractions would not be meaningful due to the difference in moisture of the surface. Therefore, soil silt fraction analysis is based on samples obtained at 28, 61 , and 103 days following product applications. The analysis of each data set includes summary statistics, ANOVA tables, and Tukey-Kramer reports for each day of collected data. The results from each day of measurement are presented individually in sections 6.2.1 through 6.2.3. A summary of all data is presented in section 6.2.4.

\subsubsection{Day-28 Analysis}

Figure 6.18 shows the summary of fit for Day-28 data. A coefficient of determination $\left(\mathrm{R}^{2}\right)$ of 0.850 indicates a positive association between treatment type and soil silt fraction. The one way ANOVA results, Figure 6.19, indicate strong evidence $(\mathrm{P}<0.0001)$ against the null hypothesis that the population means are equal. Therefore, it can be said that the means of groups are significantly different.

\begin{tabular}{|lr|}
\hline Summary of Fit & \\
Rsquare & 0.849478 \\
Adj Rsquare & 0.78258 \\
Root Mean Square Error & 70.11254 \\
Mean of Response & 183.0319 \\
Observations (or Sum Wgts) & 27 \\
\hline
\end{tabular}

Figure 6.18 Summary of Fit for Day-28 Soil Silt Fractions Data 


\begin{tabular}{|lrrrrr|}
\hline \multicolumn{7}{|l|}{ Analysis of Variance } \\
Source & DF & S Sum of & & \\
Treat & 8 & 499364.61 & 62420.6 & 12.6980 & $<.0001^{*}$ \\
Error & 18 & 88483.84 & 4915.8 & & \\
C. Total & 26 & 587848.45 & & & \\
\hline
\end{tabular}

Figure 6.19 ANOVA Table for Day-28 Soil Silt Fractions Data

Figure 6.20 displays the connecting letter report for the Tukey-Kramer multiple comparison method. There are no significant differences among the mean silt fractions of Petrotac, Tech Suppress, Dust Fyghter, Calcium Chloride, and Untreated 2; all of these have letter "E." The section treated with EK35 had a mean silt fraction similar to the untreated control sections.

\begin{tabular}{|llc|}
\hline Level & & Mean \\
Untreated 4 & A & 422.99667 \\
EK35 & A B & 326.75333 \\
Untreated 1 & A B C & 278.81000 \\
Untreated 3 & A B C D & 238.85667 \\
Untreated 2 & B C D E & 176.41000 \\
Calcium Chloride & C D E & 111.21667 \\
Dust Fyghter & D E & 46.71667 \\
Tech Suppress & D E & 42.39667 \\
Petrotac & E & 3.13000 \\
Levels not connected by same letter are significantly different. \\
\hline
\end{tabular}

Figure 6.20 Tukey-Kramer Connecting Letter Report for Day-28 Soil Silt Fractions Data

\subsubsection{Day-61 Analysis}

Figure 6.21 shows the summary of fit for Day-61 data. A coefficient of determination $\left(R^{2}\right)$ of 0.665 indicates a weak positive association between treatment type and soil silt fraction. The one way ANOVA results, Figure 6.22, indicate strong evidence $(\mathrm{P}<0.0040)$ against the null hypothesis that the population means are equal. Therefore, it can be said that the means of groups are significantly different. 


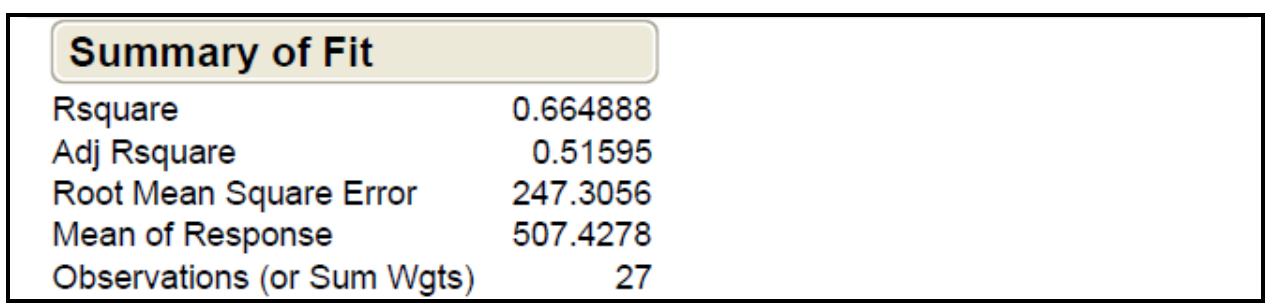

Figure 6.21 Summary of Fit for Day-61 Soil Silt Fractions Data

\begin{tabular}{|c|c|c|c|c|c|}
\hline \multicolumn{6}{|c|}{ Analysis of Variance } \\
\hline Source & DF & $\begin{array}{r}\text { Sum of } \\
\text { Squares }\end{array}$ & Mean Square & F Ratio & Prob $>$ F \\
\hline Treat & 8 & 2184234.2 & 273029 & 4.4642 & $0.0040^{*}$ \\
\hline Error & 18 & 1100880.7 & 61160 & & \\
\hline C. Total & 26 & 3285115.0 & & & \\
\hline
\end{tabular}

Figure 6.22 ANOVA Table for Day-61 Soil Silt Fractions Data

Figure 6.23 displays the connecting letter report for the Tukey-Kramer multiple comparison method. There are no significant differences among the mean silt fractions of Petrotac, Dust Fyghter, Calcium Chloride, EK35, and untreated sections 1, 2, and 4; all of these have letter "C."

\begin{tabular}{|llc|}
\hline Level & & Mean \\
Untreated 3 & A & 861.62000 \\
Tech Suppress & A B & 778.61333 \\
Untreated 4 & A B C & 714.25000 \\
Untreated 2 & A B C & 624.10000 \\
EK35 & A B C & 607.28000 \\
Untreated 1 & A B C & 571.35000 \\
Calcium Chloride A B C & 303.28333 \\
Dust Fyghter & B C & 99.42000 \\
Petrotac & C & 6.93333 \\
Levels not connected by same letter are significantly different. \\
\hline
\end{tabular}

Figure 6.23 Tukey-Kramer Connecting Letter Report for Day-61 Soil Silt Fractions Data

\subsubsection{Day-103 Analysis}

Figure 6.24 shows the summary of fit for Day-103 data. A coefficient of determination $\left(\mathrm{R}^{2}\right)$ of 0.887 indicates a positive association between treatment type and soil silt fraction. The one way ANOVA results, Figure 6.25, indicate strong evidence $(\mathrm{P}<0.0001)$ against the null 
hypothesis that the population means are equal. Therefore, it can be said that the means of groups are significantly different.

\begin{tabular}{|lr|}
\hline Summary of Fit & \\
Rsquare & 0.887095 \\
Adj Rsquare & 0.836915 \\
Root Mean Square Error & 47.14564 \\
Mean of Response & 147.5267 \\
Observations (or Sum Wgts) & 27 \\
\hline
\end{tabular}

Figure 6.24 Summary of Fit for Day-103 Soil Silt Fractions Data

\begin{tabular}{|lrrrrr|}
\hline \multicolumn{7}{|c|}{ Analysis of Variance } \\
Source & DF & Sum of & & \\
Squares & Mean Square & F Ratio & Prob > F \\
Error & 8 & 314349.72 & 39293.7 & 17.6783 & $<.0001^{*}$ \\
C. Total & 18 & 40008.80 & 2222.7 & & \\
\hline
\end{tabular}

Figure 6.25 ANOVA Table for Day-103 Soil Silt Fractions Data

Figure 6.26 displays the connecting letter report for the Tukey-Kramer multiple comparison method. The mean silt fraction of Untreated 4 was significantly higher than all other sections. There are no significant differences among the mean silt fractions of Petrotac, Calcium Chloride, Dust Fyghter, EK35, Untreated 1, and Untreated 3; all of these have letter "D."

\begin{tabular}{|llcc|}
\hline Level & & Mean \\
Untreated 4 & A & 411.30333 \\
Tech Suppress & B & 212.04333 \\
Untreated 2 & B C & 172.94333 \\
EK35 & B C D & 158.47333 \\
Untreated 3 & B C D & 111.35000 \\
Dust Fyghter & B C D & 88.57333 \\
Calcium Chloride & B C D & 84.04667 \\
Petrotac & C D & 55.35000 \\
Untreated 1 & D & 33.65667 \\
Levels not connected by same letter are significantly different.
\end{tabular}

Figure 6.26 Tukey-Kramer Connecting Letter Report for Day-103 Soil Silt Fractions Data 


\subsubsection{Comparison of Soil Silt Fractions across Time}

Figures 6.27 and 6.28 are graphs which summarize all silt fractions data (in $\mathrm{g} / \mathrm{m}^{2}$ ) over the evaluation period. At Day-28, there were no significant differences among the mean silt fractions of Petrotac, Tech Suppress, Dust Fyghter, Calcium Chloride, and Untreated 2 and the section treated with EK35 had a mean silt fraction similar to the untreated control sections. At Day-61, there were no significant differences among the mean silt fractions of Petrotac, Dust Fyghter, Calcium Chloride, EK35, and untreated sections 1, 2, and 4. At Day-103, there were no significant differences among the mean silt fractions of Petrotac, Calcium Chloride, Dust Fyghter, EK35, Untreated 1, and Untreated 3. The mean silt fraction of Untreated 4 was significantly higher than all other sections for Days 28 and 103. This section had higher sunlight exposure than the other sections. 


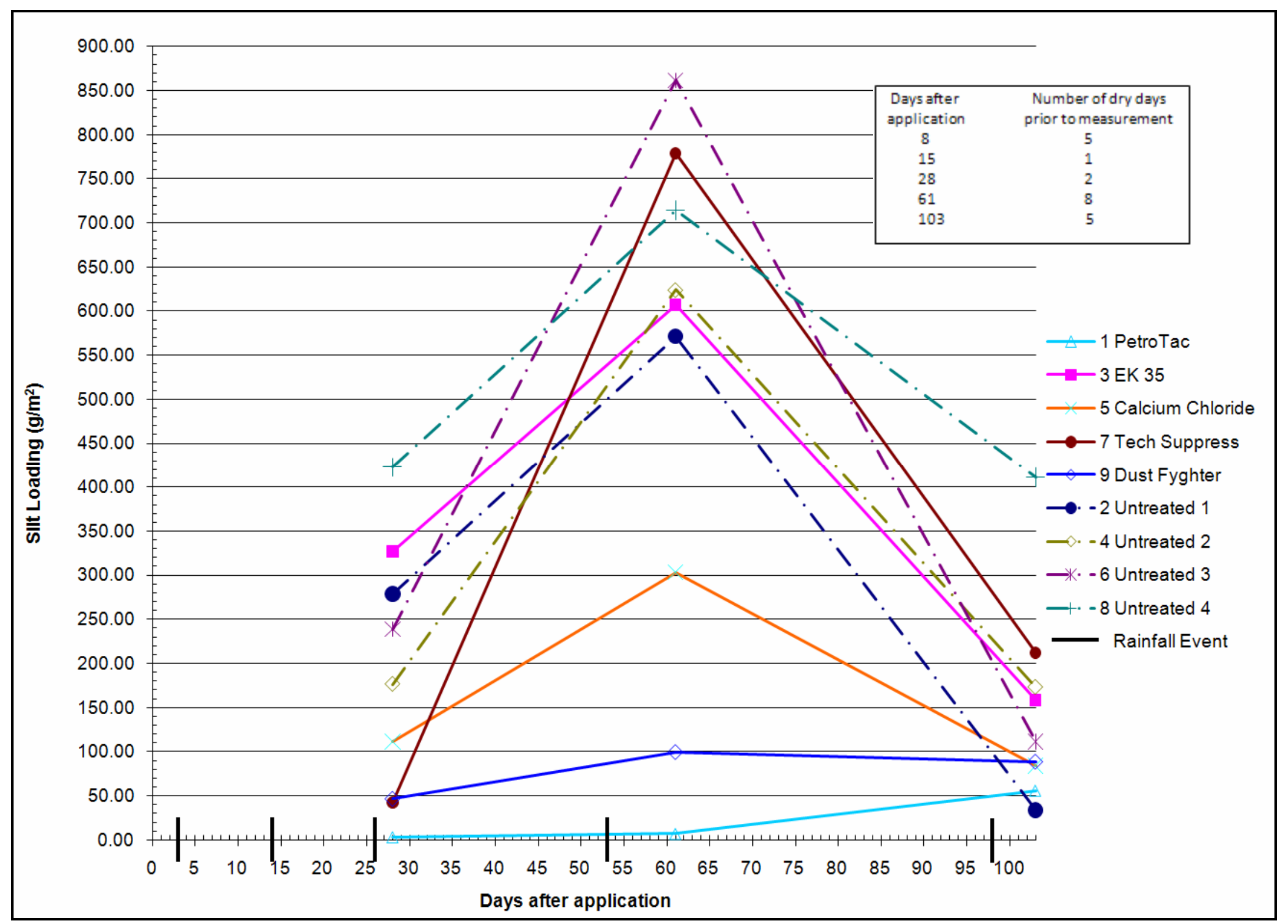

Figure 6.27 Trends of Soil Silt Fractions across Time 


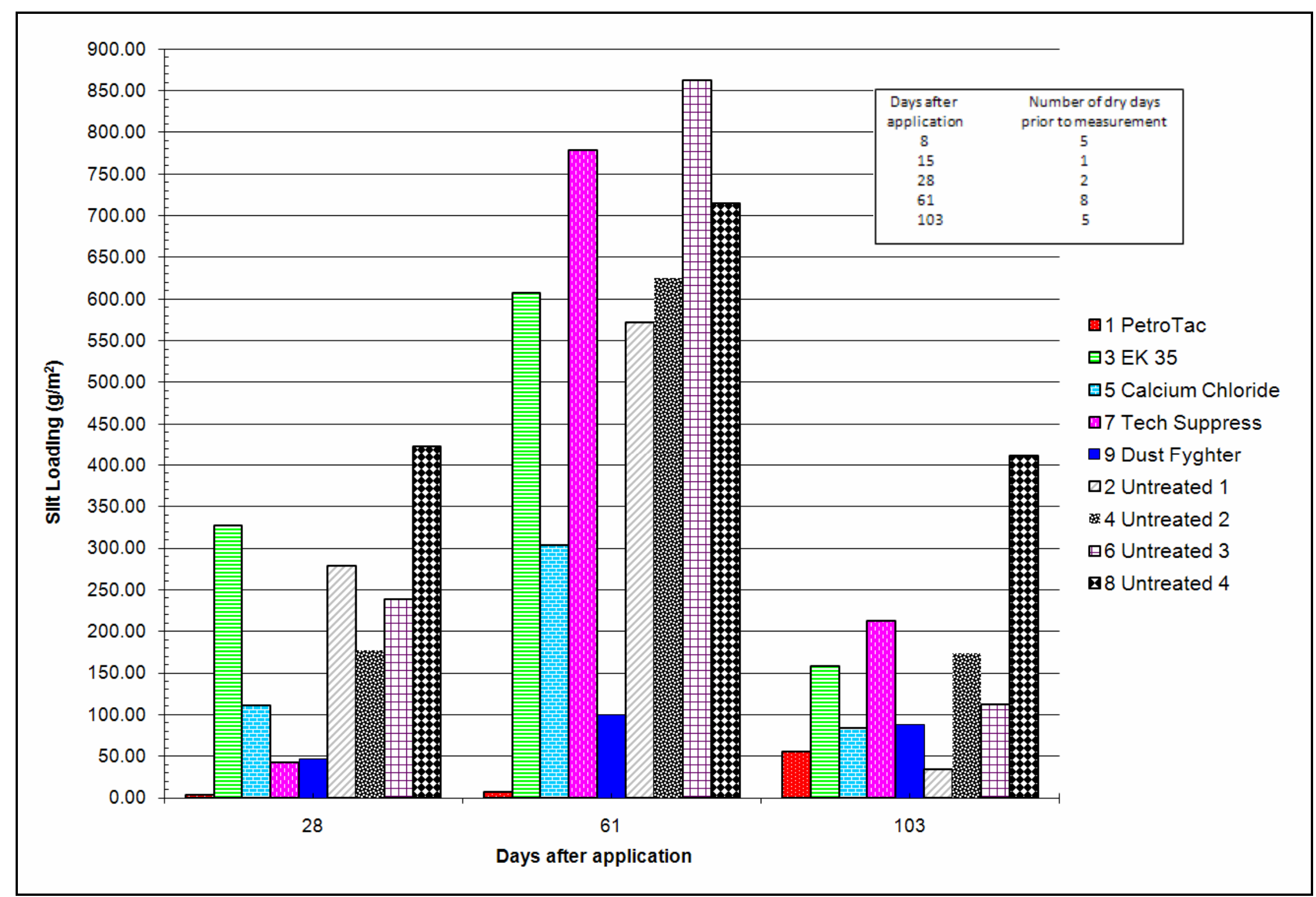

Figure 6.28 Bar Chart Summarizing Soil Silt Load Data across Time 


\subsection{SOIL MOISTURE CONTENTS}

Raw data obtained for soil moisture contents is presented in Appendix G. Soil samples for Day-145 were to be collected one day after dust measurements; however this was prohibited due to six consecutive days of rainfall which began on the planned day of soil sample collections. Therefore data for soil moisture content is based on samples obtained at 8, 28, 61, and 103 days following product applications. Each data set includes summary statistics, ANOVA tables, and Tukey-Kramer reports for each day of collected data. The results from each day of measurement are presented individually in sections 6.3.1 through 6.3.4. A summary of all data is presented in section 6.3.5.

\subsubsection{Day-7 Analysis}

Figure 6.29 shows the summary of fit for Day-8 data. A coefficient of determination $\left(\mathrm{R}^{2}\right)$ of 0.930 indicates a strong positive association between treatment type and soil moisture content. The one way ANOVA results, Figure 6.30, indicate strong evidence $(\mathrm{P}<0.0001)$ against the null hypothesis that the population means are equal. Therefore, it can be said that the means of groups are significantly different.

\begin{tabular}{|lr|}
\hline Summary of Fit \\
Rsquare & 0.930148 \\
Adj Rsquare & 0.899103 \\
Root Mean Square Error & 0.150148 \\
Mean of Response & 0.541111 \\
Observations (or Sum Wgts) & 27 \\
\hline
\end{tabular}

Figure 6.29 Summary of Fit for Day-8 Soil Moisture Content Data 


\begin{tabular}{|lrrrrr|}
\hline \multicolumn{5}{|l|}{ Analysis of Variance } \\
Source & DF & Sum of & & \\
Treat & 8 & 5.4036667 & & & \\
Error & 18 & 0.4058000 & 0.675458 & 29.9612 & $<.0001^{*}$ \\
C. Total & 26 & 5.8094667 & & & \\
\hline
\end{tabular}

Figure 6.30 ANOVA Table for Day-8 Soil Moisture Content Data

Figure 6.31 displays the connecting letter report for the Tukey-Kramer multiple comparison method. The section treated with Calcium Chloride has the highest mean soil moisture content at $1.69 \%$. There are no significant differences among the mean moisture contents of Tech Suppress, Untreated 3, and EK35; all of these have letter "B." No significant differences are found among the mean moisture contents of EK35, Petrotac, Dust Fyghter, and untreated controls 1, 2, and 4; all of these have letter "C."

\begin{tabular}{|lrrr|}
\hline Level & & \multicolumn{1}{c|}{ Mean } \\
Calcium Chloride & & & 1.6866667 \\
Tech Suppress & B & 0.8500000 \\
Untreated 3 & B C & 0.5466667 \\
EK35 & B C & 0.4333333 \\
Untreated 2 & C & 0.3400000 \\
Petrotac & C & 0.3100000 \\
Untreated 4 & C & 0.2933333 \\
Dust Fyghter & C & 0.2233333 \\
Untreated 1 & C & 0.1866667 \\
Levels not connected by same letter are significantly different. \\
\hline
\end{tabular}

Figure 6.31 Tukey-Kramer Connecting Letter Report for Day-8 Soil Moisture Content Data

\subsubsection{Day-28 Analysis}

Figure 6.32 shows the summary of fit for Day-28 data. A coefficient of determination $\left(\mathrm{R}^{2}\right)$ of 0.666 indicates a weak positive association between treatment type and soil moisture content. The one way ANOVA results, Figure 6.33, indicate strong evidence $(\mathrm{P}<0.0039)$ against the null hypothesis that the population means are equal. Therefore, it can be said that the means of groups are significantly different. 


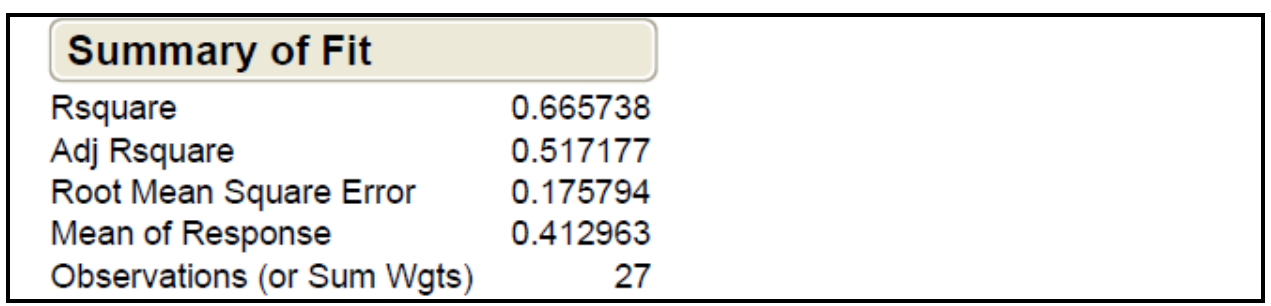

Figure 6.32 Summary of Fit for Day-28 Soil Moisture Content Data

\begin{tabular}{|c|c|c|c|c|c|}
\hline \multicolumn{6}{|c|}{ Analysis of Variance } \\
\hline Source & DF & $\begin{array}{l}\text { Sum of } \\
\text { Squares }\end{array}$ & Mean Square & F Ratio & Prob $>$ F \\
\hline Treat & 8 & 1.1078963 & 0.138487 & 4.4812 & $0.0039^{*}$ \\
\hline Error & 18 & 0.5562667 & 0.030904 & & \\
\hline C. Total & 26 & 1.6641630 & & & \\
\hline
\end{tabular}

Figure 6.33 ANOVA Table for Day-28 Soil Moisture Content Data

Figure 6.34 displays the connecting letter report for the Tukey-Kramer multiple comparison method. There are no significant differences among the mean moisture contents of Calcium Chloride, Petrotac, Tech Suppress, Untreated 1, and Untreated 3; all of these have letter "A."

\begin{tabular}{|lrr|}
\hline Level & & Mean \\
Calcium Chloride & A & 0.86333333 \\
Petrotac & A B & 0.58000000 \\
Tech Suppress & A B & 0.46333333 \\
Untreated 1 & A B & 0.42000000 \\
Untreated 3 & A B & 0.39000000 \\
EK35 & B & 0.36000000 \\
Untreated 2 & B & 0.30666667 \\
Untreated 4 & B & 0.17000000 \\
Dust Fyghter & B & 0.16333333 \\
Levels not connected by same letter are significantly different. \\
\hline
\end{tabular}

Figure 6.34 Tukey-Kramer Connecting Letter Report for Day-28 Soil Moisture Content Data

\subsubsection{Day-61 Analysis}

Figure 6.35 shows the summary of fit for Day-61 data. A coefficient of determination $\left(\mathrm{R}^{2}\right)$ of 0.679 indicates a weak positive association between treatment type and soil moisture content. The one way ANOVA results, Figure 6.36, indicate strong evidence $(\mathrm{P}<0.0029)$ 
against the null hypothesis that the population means are equal. Therefore, it can be said that the means of groups are significantly different.

\begin{tabular}{|lr|}
\hline Summary of Fit & \\
Rsquare & 0.679358 \\
Adj Rsquare & 0.53685 \\
Root Mean Square Error & 0.234442 \\
Mean of Response & 0.495185 \\
Observations (or Sum Wgts) & 27 \\
\hline
\end{tabular}

Figure 6.35 Summary of Fit for Day-61 Soil Moisture Content Data

\begin{tabular}{|lrrrrr|}
\hline \multicolumn{5}{|c|}{ Analysis of Variance } \\
Source & DF & Sum of & & & \\
Squares & Mean Square & F Ratio & Prob > F \\
Error & 8 & 2.0961407 & 0.262018 & 4.7672 & $0.0029^{*}$ \\
C. Total & 18 & 0.9893333 & 0.054963 & & \\
\hline
\end{tabular}

Figure 6.36 ANOVA Table for Day-61 Soil Moisture Content Data

Figure 6.37 displays the connecting letter report for the Tukey-Kramer multiple comparison method. There are no significant differences among the mean moisture contents of Calcium Chloride, EK35, Petrotac, Tech Suppress, and untreated controls 1, 2, and 3; all of these have letter "A."

\begin{tabular}{|lll|}
\hline Level & & \multicolumn{1}{c|}{ Mean } \\
Calcium Chloride & A & 0.94666667 \\
Untreated 3 & A & 0.85000000 \\
Untreated 1 & A B & 0.74333333 \\
EK35 & A B & 0.56333333 \\
Petrotac & A B & 0.37000000 \\
Untreated 2 & A B & 0.35000000 \\
Tech Suppress & A B & 0.33666667 \\
Dust Fyghter & B & 0.16000000 \\
Untreated 4 & B & 0.13666667 \\
Levels not connected by same letter are significantly different. \\
\hline
\end{tabular}

Figure 6.37 Tukey-Kramer Connecting Letter Report for Day-61 Soil Moisture Content Data

\subsubsection{Day-103 Analysis}

Figure 6.38 shows the summary of fit for Day-103 data. A coefficient of determination $\left(\mathrm{R}^{2}\right)$ of 0.940 indicates a strong positive association between treatment type and soil moisture 
content. The one way ANOVA results, Figure 6.39, indicate strong evidence $(\mathrm{P}<0.0001)$

against the null hypothesis that the population means are equal. Therefore, it can be said that the means of groups are significantly different.

\begin{tabular}{|lr|}
\hline Summary of Fit \\
Rsquare & 0.939681 \\
Adj Rsquare & 0.912873 \\
Root Mean Square Error & 0.190127 \\
Mean of Response & 0.778519 \\
Observations (or Sum Wgts) & 27 \\
\hline
\end{tabular}

Figure 6.38 Summary of Fit for Day-103 Soil Moisture Content Data

\begin{tabular}{|c|c|c|c|c|c|}
\hline \multicolumn{6}{|c|}{ Analysis of Variance } \\
\hline Source & DF & $\begin{array}{r}\text { Sum of } \\
\text { Squares }\end{array}$ & Mean Square & F Ratio & Prob $>$ F \\
\hline Treat & 8 & 10.136474 & 1.26706 & 35.0518 & $<.0001^{*}$ \\
\hline Error & 18 & 0.650667 & 0.03615 & & \\
\hline C. Total & 26 & 10.787141 & & & \\
\hline
\end{tabular}

Figure 6.39 ANOVA Table for Day-103 Soil Moisture Content Data

Figure 6.40 displays the connecting letter report for the Tukey-Kramer multiple comparison method. Untreated 3 has the highest mean soil moisture content at $2.40 \%$. There are no differences in the mean moisture contents of sections treated with Calcium Chloride, Dust Fyghter, EK 35, and Untreated 2.

\begin{tabular}{|lrrr|}
\hline Level & & & \multicolumn{1}{c|}{ Mean } \\
Untreated 3 & A & & 2.3966667 \\
Calcium Chloride & B & 1.0733333 \\
Untreated 2 & B C & 0.7966667 \\
Dust Fyghter & B C & 0.5600000 \\
EK35 & B C & 0.5466667 \\
Petrotac & C & 0.5000000 \\
Tech Suppress & C & 0.4533333 \\
Untreated 1 & C & 0.3833333 \\
Untreated 4 & C & 0.2966667 \\
Levels not connected by same letter are significantly different. \\
\hline
\end{tabular}

Figure 6.40 Tukey-Kramer Connecting Letter Report for Day-103 Soil Moisture Content Data 


\subsubsection{Comparison of Soil Moisture Content Data across Time}

Figures 6.41 and 6.42 are graphs which summarize all moisture content data (in \%) over

the evaluation period. At Day-8, the section treated with Calcium Chloride had the highest mean soil moisture content at $1.69 \%$. At Day-28, there were no significant differences among the mean moisture contents of Calcium Chloride, Petrotac, Tech Suppress, Untreated 1, and Untreated 3. At Day-61, there were no significant differences among the mean moisture contents of Calcium Chloride, EK35, Petrotac, Tech Suppress, and untreated controls 1, 2, and 3. At Day-103, Untreated 3 had the highest mean soil moisture content at $2.40 \%$ and there were no differences in the mean moisture contents of sections treated with Calcium Chloride, Dust Fyghter, EK 35, and Untreated 2. 


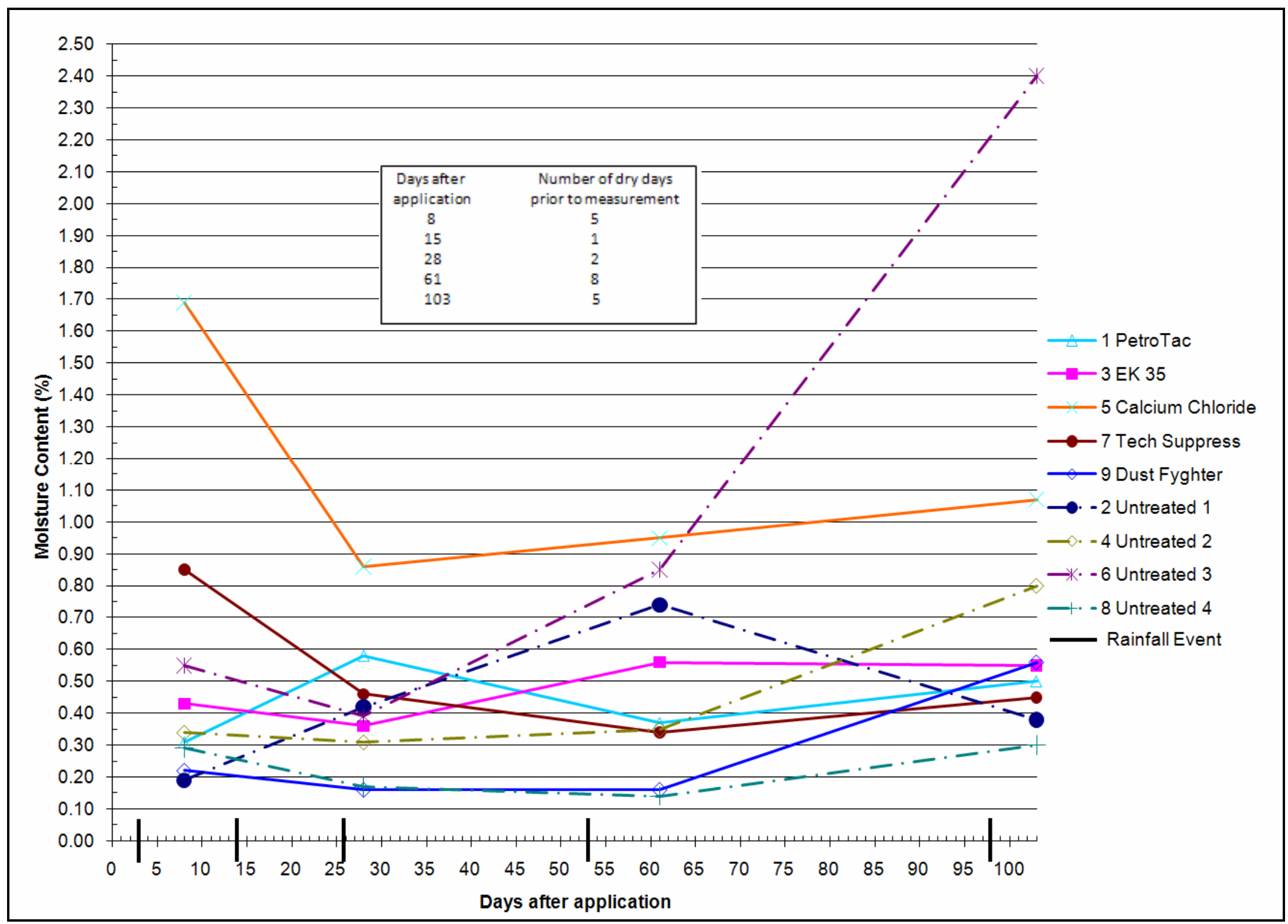

Figure 6.41 Trends of Soil Moisture Contents across Time 


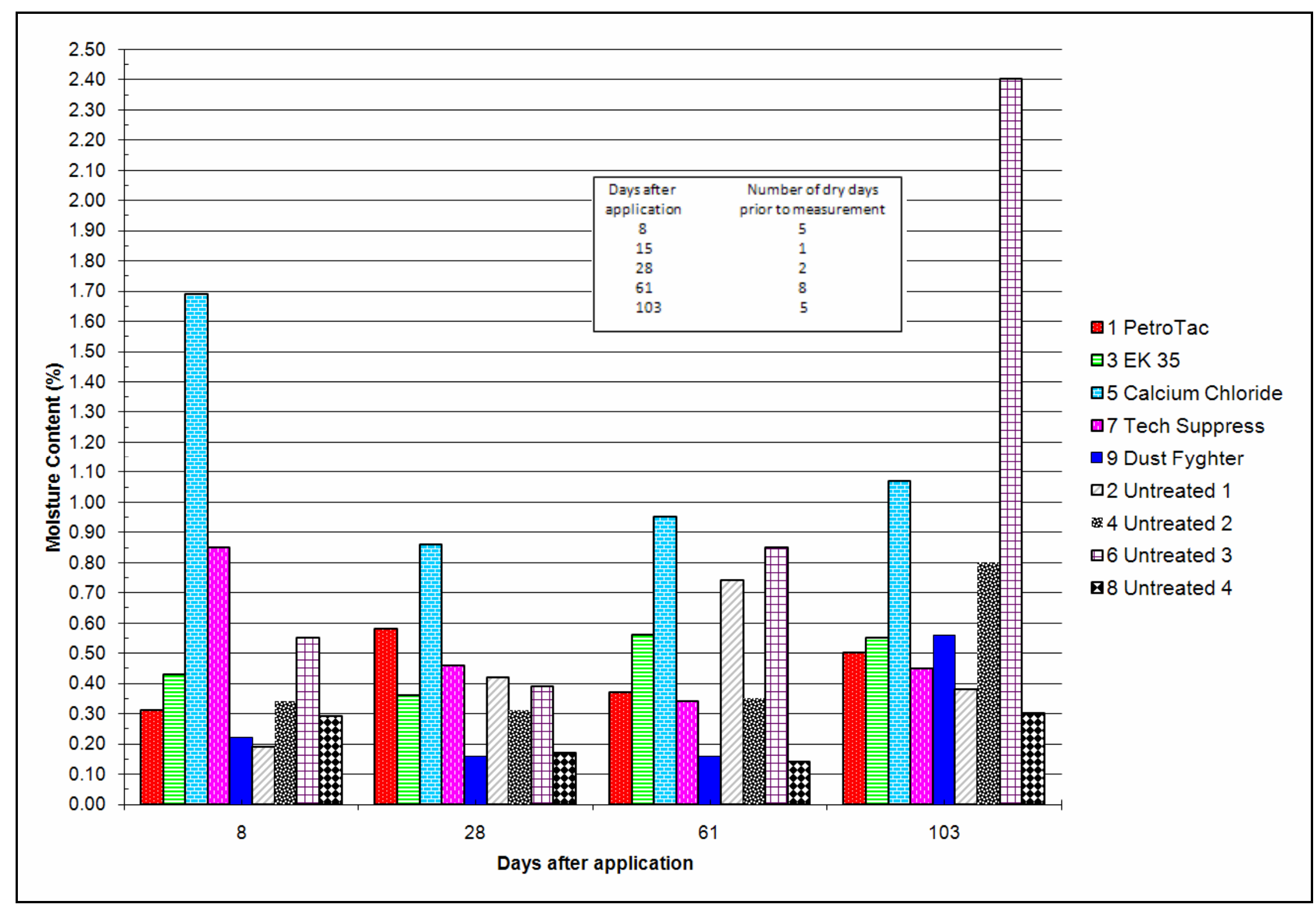

Figure 6.42 Bar Chart Summarizing Soil Moisture Contents across Time 


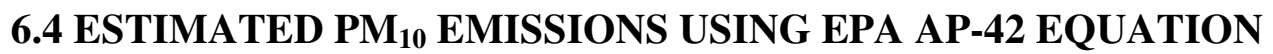

For each test section, $\mathrm{PM}_{10}$ emissions produced by the test vehicle were estimated using Equation 2.2. This equation is dependent upon surface material silt content (\%), surface material moisture content $(\%)$, mean vehicle speed (mph), and an emission factor for vehicle fleet exhaust, brake wear, and tire wear. $\mathrm{PM}_{10}$ emissions estimates were only calculated for 8, 28, 61, and 103 days following product applications since surface material silt and moisture contents were obtained for these days. In section 6.2, silt load data for Day-8 were not analyzed. The following analysis is based on percent silt which was measured for the Day-8 samples. The results from each day of measurement are presented individually in sections 6.4.1 through 6.4.4. A summary of all data is presented in section 6.4.5. Raw data obtained for $\mathrm{PM}_{10}$ emissions estimates is presented in Appendix $\mathrm{H}$.

\subsubsection{Day-8 Analysis}

Figure 6.43 shows the summary of fit for Day-8 data. A coefficient of determination $\left(\mathrm{R}^{2}\right)$ of 0.906 indicates a strong positive association between treatment type and estimated $\mathrm{PM}_{10}$ emissions. The one way ANOVA results, Figure 6.44, indicate strong evidence $(\mathrm{P}<0.0001)$ against the null hypothesis that the population means are equal. Therefore, it can be said that the means of groups are significantly different.

\begin{tabular}{|lr|}
\hline Summary of Fit & \\
Rsquare & 0.906036 \\
Adj Rsquare & 0.864274 \\
Root Mean Square Error & 0.146059 \\
Mean of Response & 0.444815 \\
Observations (or Sum Wgts) & 27 \\
\hline
\end{tabular}

Figure 6.43 Summary of Fit for Day-8 Estimated PM $_{10}$ Emissions 


\begin{tabular}{|c|c|c|c|c|c|}
\hline \multicolumn{6}{|c|}{ Analysis of Variance } \\
\hline Source & DF & $\begin{array}{r}\text { Sum of } \\
\text { Squares }\end{array}$ & Mean Square & F Ratio & Prob $>$ F \\
\hline Treat & 8 & 3.7026741 & 0.462834 & 21.6954 & $<.0001^{*}$ \\
\hline Error & 18 & 0.3840000 & 0.021333 & & \\
\hline C. Total & 26 & 4.0866741 & & & \\
\hline
\end{tabular}

Figure 6.44 ANOVA Table for Day-8 Estimated PM Amissions $_{10}$ Emis

Figure 6.45 displays the connecting letter report for the Tukey-Kramer multiple comparison method. There are no significant differences among the mean estimated $\mathrm{PM}_{10}$ emissions of sections treated with Petrotac, Dust Fyghter, Tech Suppress, EK35, and Calcium Chloride; all of these have letter "C." No significant differences are found among untreated section 1, 2, and 3; all of these have letter "B." There are no significant differences among untreated sections 1,3 , and 4 ; all of these have letter "A."

\begin{tabular}{|lrrr|}
\hline Level & & & Mean \\
Untreated 4 & A & 1.1266667 \\
Untreated 3 & A B & 0.7700000 \\
Untreated 1 & A B & 0.7500000 \\
Untreated 2 & B & 0.6833333 \\
Calcium Chloride & C & 0.2366667 \\
EK35 & C & 0.2300000 \\
Tech Suppress & C & 0.0766667 \\
Dust Fyghter & C & 0.0666667 \\
Petrotac & C & 0.0633333 \\
Levels not connected by same letter are significantly different. \\
\hline
\end{tabular}

Figure 6.45 Tukey-Kramer Connecting Letter Report for Day-8 Estimated $\mathrm{PM}_{10}$ Emissions

\subsubsection{Day-28 Analysis}

Figure 6.46 shows the summary of fit for Day-28 data. A coefficient of determination $\left(\mathrm{R}^{2}\right)$ of 0.0.298 indicates a very weak positive association between treatment type and estimated $\mathrm{PM}_{10}$ emissions. The one way ANOVA results, Figure 6.47 , indicate strong evidence $(\mathrm{P}=$ 0.4985 ) that the null hypothesis cannot be rejected at the $5 \%$ level of significance. Therefore, it can be said that the means of groups are equal. 


\begin{tabular}{|lr|}
\hline Summary of Fit & \\
Rsquare & 0.298057 \\
Adj Rsquare & -0.01392 \\
Root Mean Square Error & 8.774887 \\
Mean of Response & 2.436667 \\
Observations (or Sum Wgts) & 27 \\
\hline
\end{tabular}

Figure 6.46 Summary of Fit for Day-28 Estimated $\mathrm{PM}_{10}$ Emissions

\begin{tabular}{|c|c|c|c|c|c|}
\hline \multicolumn{6}{|c|}{ Analysis of Variance } \\
\hline Source & DF & $\begin{array}{r}\text { Sum of } \\
\text { Squares }\end{array}$ & Mean Square & F Ratio & Prob $>$ F \\
\hline Treat & 8 & 588.5078 & 73.5635 & 0.9554 & 0.4985 \\
\hline Error & 18 & 1385.9754 & 76.9986 & & \\
\hline C. Total & 26 & 1974.4832 & & & \\
\hline
\end{tabular}

Figure 6.47 ANOVA Table for Day-28 Estimated $\mathrm{PM}_{10}$ Emissions

\subsubsection{Day-61 Analysis}

Figure 6.48 shows the summary of fit for Day-61 data. A coefficient of determination $\left(\mathrm{R}^{2}\right)$ of 0.914 indicates a strong positive association between treatment type and estimated $\mathrm{PM}_{10}$ emissions. The one way ANOVA results, Figure 6.49, indicate strong evidence $(\mathrm{P}<0.0001)$ against the null hypothesis that the population means are equal. Therefore, it can be said that the means of groups are significantly different.

\begin{tabular}{|lr|}
\hline Summary of Fit & \\
Rsquare & 0.913922 \\
Adj Rsquare & 0.875665 \\
Root Mean Square Error & 0.212272 \\
Mean of Response & 1.494444 \\
Observations (or Sum Wgts) & 27 \\
\hline
\end{tabular}

Figure 6.48 Summary of Fit for Day-61 Estimated PM $_{10}$ Emissions

\begin{tabular}{|lrrrrr|}
\hline \multicolumn{5}{|l|}{ Analysis of Variance } \\
Source & DF & $\begin{array}{r}\text { Sum of } \\
\text { Squares }\end{array}$ & Mean Square & F Ratio & Prob $>$ F \\
Treat & 8 & 8.6114000 & 1.07642 & 23.8891 & $<.0001^{*}$ \\
Error & 18 & 0.8110667 & 0.04506 & & \\
C. Total & 26 & 9.4224667 & & & \\
\hline
\end{tabular}

Figure 6.49 ANOVA Table for Day-61 Estimated PM $_{10}$ Emissions 
Figure 6.50 displays the connecting letter report for the Tukey-Kramer multiple comparison method. The mean estimated $\mathrm{PM}_{10}$ emissions of the section treated with Petrotac is significantly less than all other sections, as indicated by letter "E." There are no significant differences among the means of sections treated with Dust Fyghter, Calcium Chloride, and EK35; all of these have letter "D." No significant differences exist among the means of sections treated with Calcium Chloride, EK35, Tech Suppress, and Untreated 1; all of these have letter "C." There are no significant differences among the means of sections treated with Dust Fyghter, Calcium Chloride, and EK35; all of these have letter "B." No significant differences exist among the means of sections treated with Tech Suppress and all untreated control sections; all of these have letter "A."

\begin{tabular}{|c|c|c|}
\hline Level & & Mean \\
\hline Untreated 4 & A & 2.0833333 \\
\hline Untreated 3 & A B & 2.0400000 \\
\hline Untreated 2 & A B & 1.9033333 \\
\hline Untreated 1 & A B C & 1.7733333 \\
\hline Tech Suppress & A B C & 1.7533333 \\
\hline EK35 & B C D & 1.4600000 \\
\hline Calcium Chloride & C D & 1.2466667 \\
\hline Dust Fyghter & D & 0.9366667 \\
\hline Petrotac & E & 0.2533333 \\
\hline
\end{tabular}

Figure 6.50 Tukey-Kramer Connecting Letter Report for Day-61 Estimated PM 10 Emissions

\subsubsection{Day-103 Analysis}

Figure 6.51 shows the summary of fit for Day-103 data. A coefficient of determination $\left(\mathrm{R}^{2}\right)$ of 0.9929 indicates a strong positive association between treatment type and estimated $\mathrm{PM}_{10}$ emissions. The one way ANOVA results, Figure 6.52, indicate strong evidence $(\mathrm{P}<0.0001)$ against the null hypothesis that the population means are equal. Therefore, it can be said that the means of groups are significantly different. 


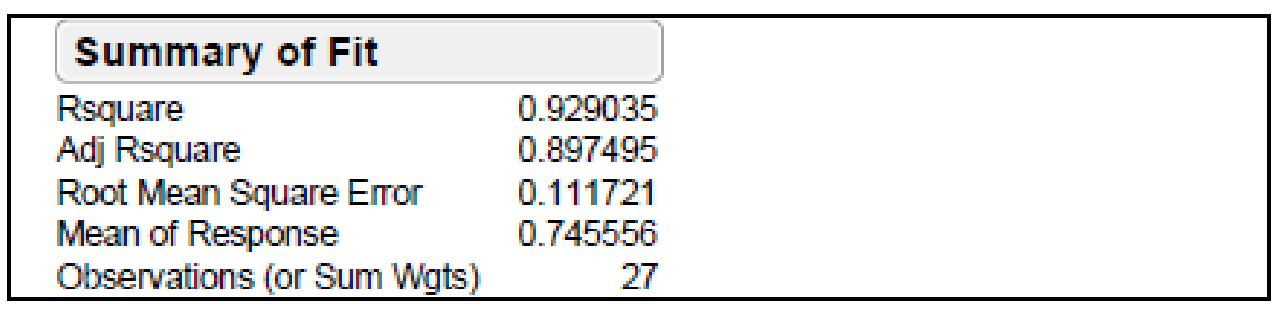

Figure 6.51 Summary of Fit for Day-103 Estimated PM $_{10}$ Emissions

\begin{tabular}{|lrrrrr|}
\hline \multicolumn{7}{|l|}{ Analysis of Variance } \\
Source & DF & $\begin{array}{r}\text { Sum of } \\
\text { Squares }\end{array}$ & Mean Square & F Ratio & Prob $>$ F \\
Treat & 8 & 2.9412000 & 0.367650 & 29.4556 & $<.0001^{\star}$ \\
Error & 18 & 0.2246667 & 0.012481 & & \\
C. Total & 26 & 3.1658667 & & & \\
\hline
\end{tabular}

Figure 6.52 ANOVA Table for Day-103 Estimated $\mathrm{PM}_{10}$ Emissions

Figure 6.53 displays the connecting letter report for the Tukey-Kramer multiple comparison method. Untreated 3 has significantly higher mean estimated $\mathrm{PM}_{10}$ emissions than all other sections. There are no differences in the mean estimated $\mathrm{PM}_{10}$ emissions of sections treated with Petrotac, Dust Fyghter, Tech Suppress, Calcium Chloride, and untreated sections 1, and 3; all of these have letter "C."

\begin{tabular}{|lll|}
\hline Level & \multicolumn{1}{c|}{ Mean } \\
Untreated 4 & A & 1.6266667 \\
EK35 & B & 0.7900000 \\
Untreated 2 & B & 0.7533333 \\
Calcium Chloride & B C & 0.7033333 \\
Tech Suppress & B C & 0.6500000 \\
Dust Fyghter & B C & 0.6400000 \\
Untreated 3 & B C & 0.5800000 \\
Petrotac & B C & 0.5700000 \\
Untreated 1 & C & 0.3966667 \\
Levels not connected by same letter are significantly different. \\
\hline
\end{tabular}

Figure 6.53 Tukey-Kramer Connecting Letter Report for Day-103 Estimated PM 10 $_{10}$ Emissions

\subsubsection{Comparison of Estimated PM $M_{10}$ Emissions across Time}

Figures 6.54 and 6.55 are graphs which summarize and estimated $\mathrm{PM}_{10}$ emissions data (in lb/VMT) over the evaluation period. At Day-8, there are no significant differences among the mean estimated $\mathrm{PM}_{10}$ emissions of sections treated with Petrotac, Dust Fyghter, Tech 
Suppress, EK35, and Calcium Chloride; all sections treated with dust palliatives had lower estimated $\mathrm{PM}_{10}$ emissions than the untreated control sections. At Day-28, the means of all groups were equal. At Day-61, the mean estimated $\mathrm{PM}_{10}$ emissions of the section treated with Petrotac were significantly less than all other sections. At Day-103, there were no differences in the mean estimated $\mathrm{PM}_{10}$ emissions of sections treated with Petrotac, Dust Fyghter, Tech Suppress, Calcium Chloride, and untreated sections 1 and 3.

Figure 6.56 indicates a positive correlation between dust measurements and the estimates from the EPA equation. This correlation is independent of the fact that different treatments were placed on the test sections. Equation 2.2 was developed for untreated gravel roads. Figure 6.57 compares the dust measurement results to the estimates from the EPA equation for the untreated control sections. Although there is an apparent positive correlation, an $\mathrm{R}^{2}$ value of 0.40 indicates that relatively little variance between the data sets is explained by a simple regression equation. This suggests Equation 2.2 is not a reliable estimator of dust generated by vehicles traversing gravel roads. 


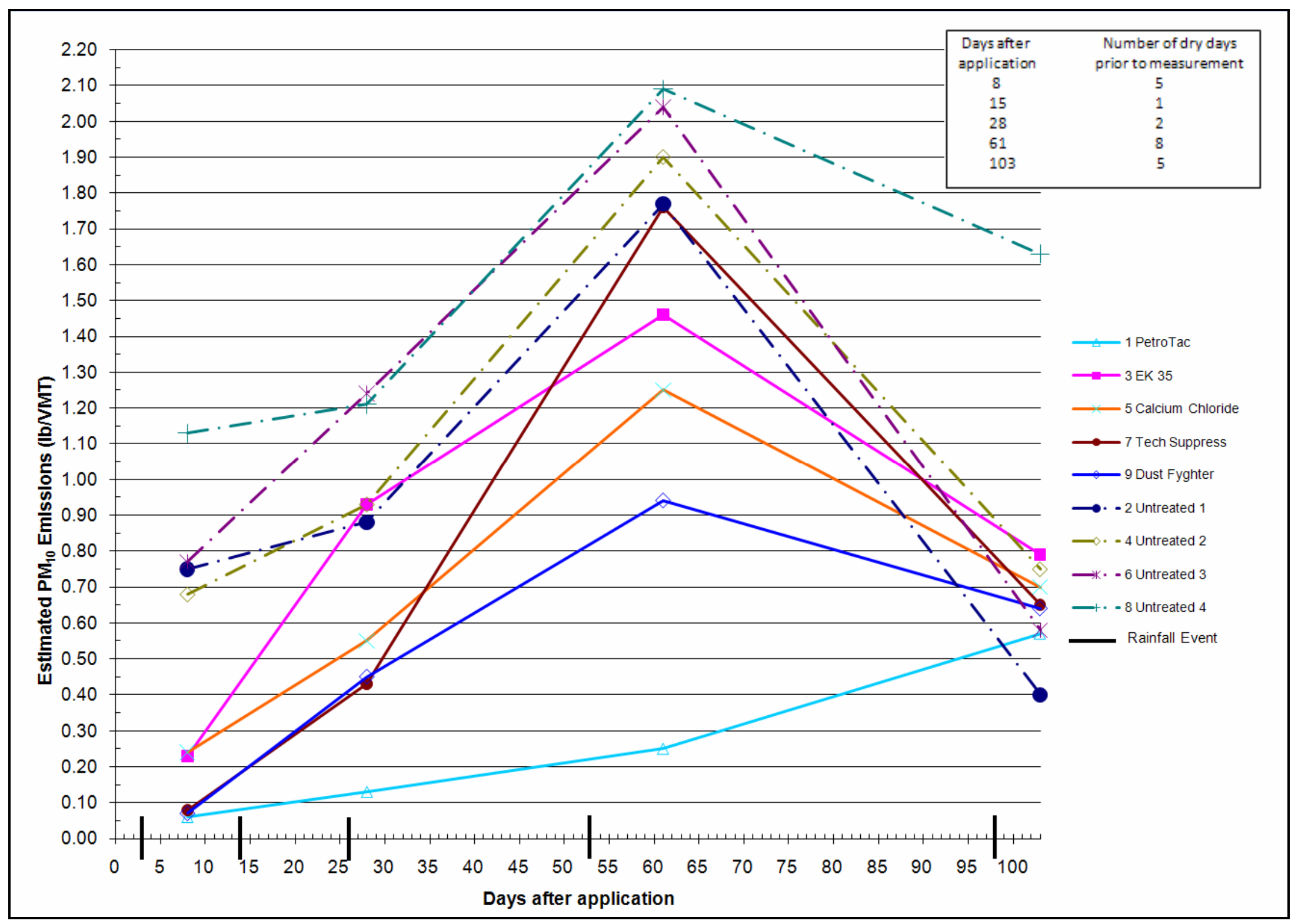

Figure 6.54 Trends of Estimated $\mathrm{PM}_{10}$ Emissions across Time 


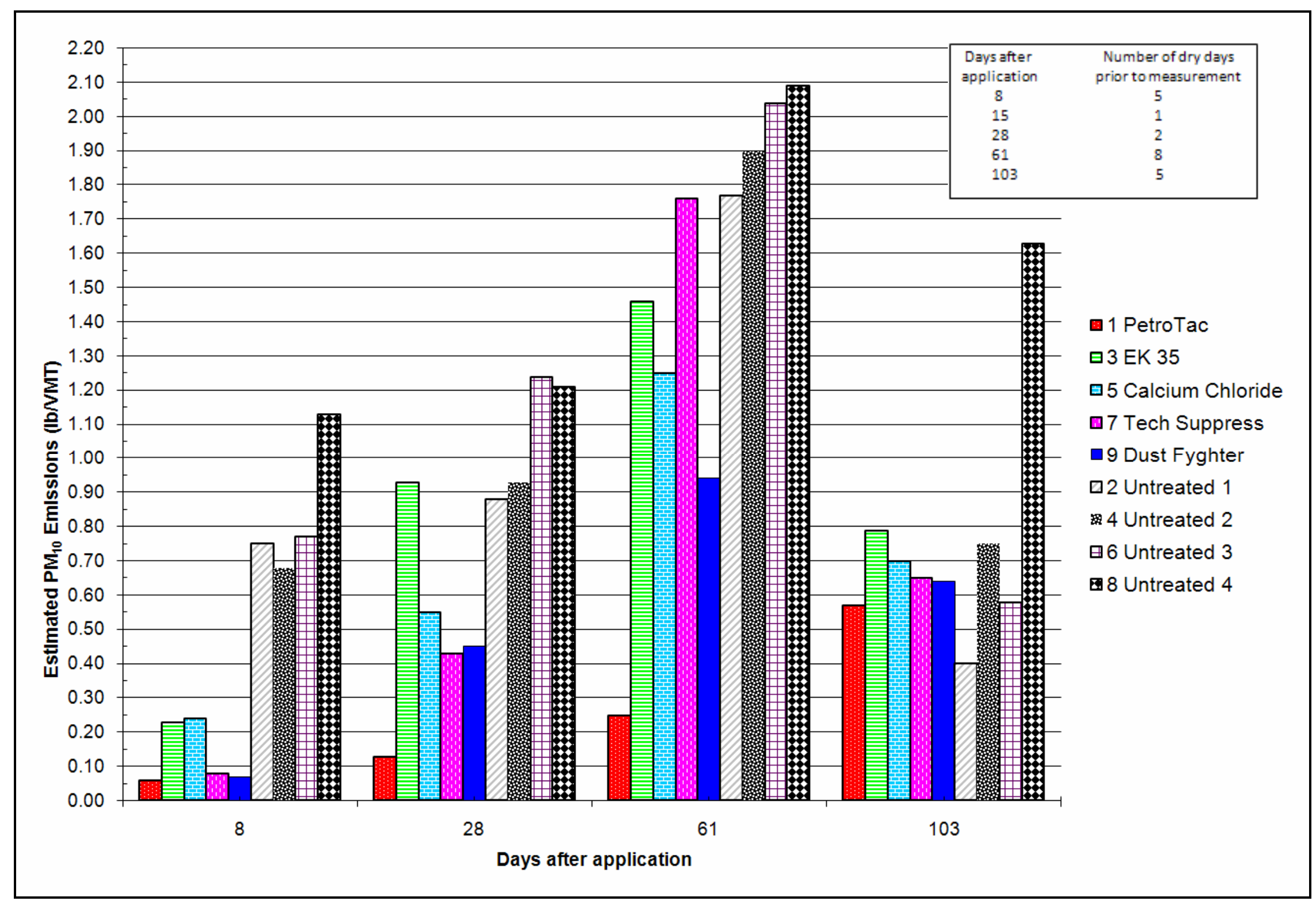

Figure 6.55 Bar Chart Summarizing Estimated $\mathrm{PM}_{10}$ Emissions across Time 


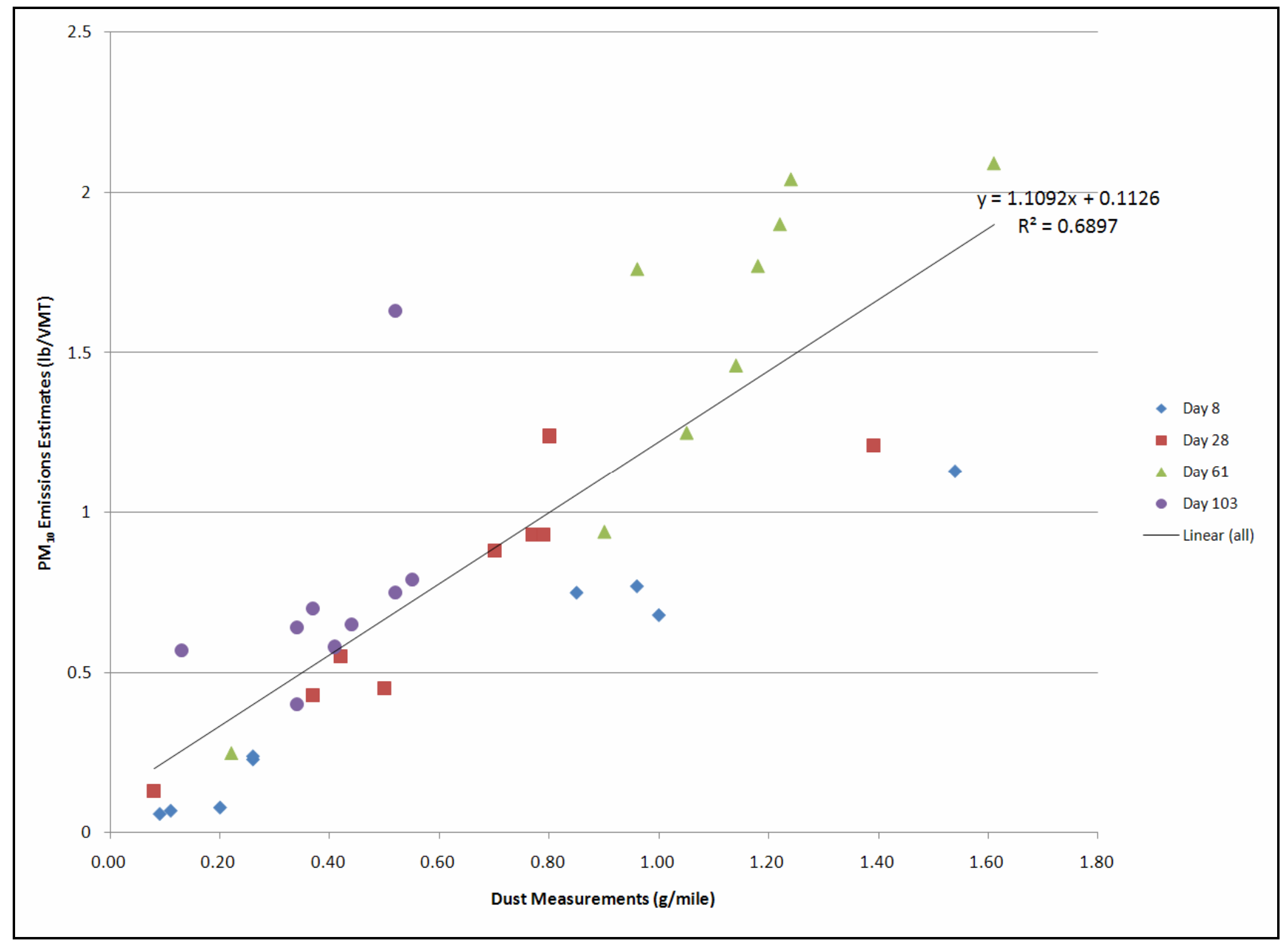

Figure 6.56 Scatter Diagram of Dust Measurements vs. Estimated $\mathrm{PM}_{10}$ Emissions for All Sections 


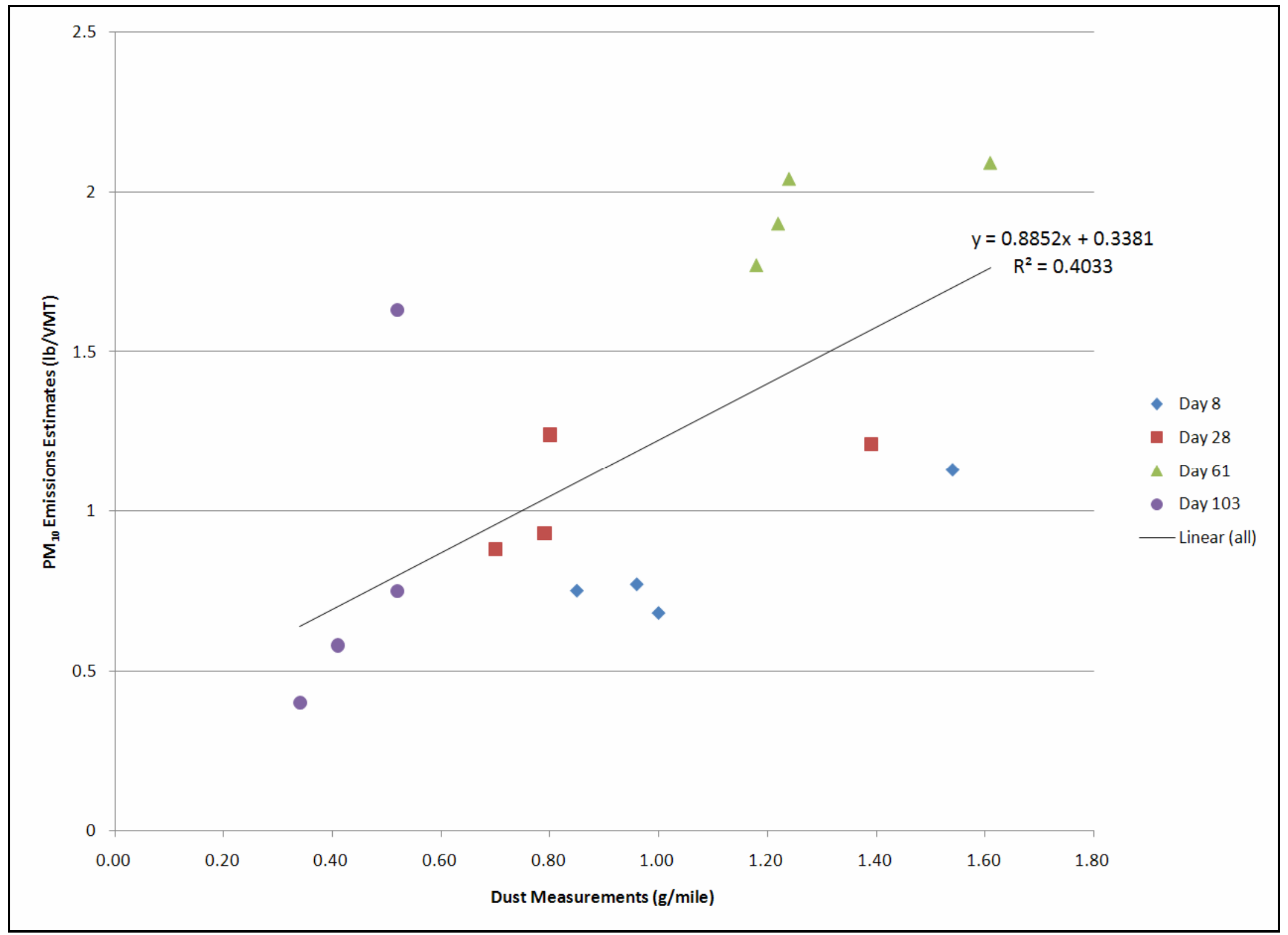

Figure 6.57 Scatter Diagram of Dust Measurements vs. Estimated $\mathrm{PM}_{10}$ Emissions for Untreated Control Sections 


\section{CHAPTER 7 CONCLUSIONS AND RECOMMENDATIONS}

\subsection{CONCLUSIONS}

The West Virginia Division of Highways sponsored this study to identify and compare, through quantitative field measurements, commercially available dust palliatives for use on gravel secondary roads. Five dust control products were selected for a three-month evaluation on a gravel secondary road in western West Virginia. The three types of testing performed on the various sections within the demonstration site included soil silt fractions, soil moisture contents and the use of a mobile dust collection device. Soil silt fractions and moisture contents were also used in the U.S. EPA AP-42 equation, Equation 2.2, for estimating $\mathrm{PM}_{10}$ emissions on an unpaved road.

Analysis of soil silt fractions alone yielded unreliable results because this test procedure did not account for the mechanisms by which all products achieved dust control. For example, when performing analyses of soil silt fractions, the soil samples were first oven dried. Since calcium chloride worked by absorbing moisture from the atmosphere, the grains held together by the retained moisture was broken down, thus indicating a higher silt fraction than its in-situ condition. However, the ability of the salts to assist with moisture retention was captured by the moisture analyses.

The EPA AP-42 equation for estimating PM $_{10}$ emissions accounted for both soil silt fractions and moisture contents. However, comparison of the dust measurement results to the estimates from the EPA equation indicated that relatively little variance between the data sets was explained by a simple regression equation, suggesting that Equation 2.2 is not a reliable estimator of dust generated by vehicles traversing gravel roads. Thus, studies comparing the 
effectiveness of dust palliatives should use a direct measurement methodology rather than relying on indirect estimates based on the surface's silt percentage and moisture content.

The mobile dust collector was an adequate device for identifying differences in the performances of various dust control products. This device could not measure the amount of dust generated along the road side and adjacent land. Since the objective of this experiment was to compare dust treatments, relative measurements of dust were adequate.

Calcium chloride proved to be effective at controlling dust, low-cost, easy to apply, produced minimal traffic impacts, had long-term storage capabilities, and showed minimal environmental effects. Although the petroleum emulsion with polymer and lignin sulfonate had similar performances after 103 days, there were concerns associated with these products.

Table 7.1 shows the estimated costs of each product used in this experiment. Calcium chloride was the least expensive product at $\$ 0.23 / \mathrm{yd}^{2}$. The synthetic organic fluid ("EK35") was the most expensive product at $\$ 1.42 / \mathrm{yd}^{2}$ yet it had the poorest results. This section deteriorated to the point of the untreated control sections within 15 days following product application making it the least cost-effective material.

Table 7.1 Estimated Costs of Products

\begin{tabular}{|c|c|c|c|}
\hline $\begin{array}{l}\text { Section } \\
\text { Number }\end{array}$ & Treatment Type & Market Name & $\begin{array}{l}\text { Cost }(\$ / y d 2) \\
\text { Applied }\end{array}$ \\
\hline 1 & $\begin{array}{l}\text { Petroleum emulsion with } \\
\text { polymer }\end{array}$ & Petrotac & $\$ 0.86$ \\
\hline 3 & Synthetic organic fluid & EK35 & $\$ 1.42$ \\
\hline 5 & Calcium chloride & Calcium chloride & $\$ 0.23$ \\
\hline 7 & Bituminous resin pitch & Tech Suppress & $\$ 0.85$ \\
\hline 9 & Lignin Sulfonate & Dust Fyghter & $\$ 0.60$ \\
\hline
\end{tabular}


Both the petroleum emulsion with polymer and the bituminous resin pitch had very long curing times, required multiple applications, and received complaints from passing motorists and residents living adjacent to test sections. These products splashed onto passing vehicles where pooling occurred on the roadway and were difficult to remove from the undercarriages and exteriors of vehicles. There were no observed constructability issues with the synthetic organic fluid, calcium chloride, and the bituminous resin pitch; all of these sections were immediately opened to traffic.

Storage concerns have been reported for lignin sulfonate, as this is derived from an organic source as a by-product of paper pulping processes. Since the synthetic organic fluid is a relatively new product, no storage concerns have been recorded; however its potential for creating problems associated with long-term storage should be considered. For long-term storage, it is recommended that calcium chloride solution be kept in aluminum tanks so as to prevent corrosion.

Among all products, the petroleum emulsion with polymer and the bituminous resin pitch created the most concern for environmental impacts, as, based on visual observations, these two products were highly flowable and leached into roadside ditches after applications. Furthermore, both of these products remained tacky for days after applications, especially in roadside ditches and other areas where pooling occurred. These products were also very odorous for approximately two weeks after applications. A strong odor was also evident on the section treated with lignin sulfonate. No product runoff was observed for lignin sulfonate, calcium chloride, or the synthetic organic fluid. 


\subsection{RECOMMENDATIONS FOR FURTHER STUDY}

This study was limited to the evaluation of commercially available dust palliatives on one gravel road in western West Virginia. Studying the performance of these dust palliatives on roads with varying geologic composition and levels of traffic would provide insight to the effectiveness of these products with different aggregates and to their performance thresholds with respect to traffic.

A 103-day evaluation period was used to assess the performance of chemical dust palliatives during the hottest and driest part of the year. A more comprehensive evaluation would include the performance of products during the winter and after freeze/thaw cycles to better determine their safety and resilience throughout the entire year.

The EPA AP-42 equation was used to estimate PM $_{10}$ emissions for each section. Two primary factors in this equation are soil silt and moisture contents; however the sensitivity of this equation to varying silt fractions and moisture contents seems suspect. Therefore, a comprehensive evaluation on the effect of varying soil silt and moisture contents should be conducted to assess the reliability of this equation in predicting $\mathrm{PM}_{10}$ emissions.

This project incorporated a technique to effectively quantify the relative amounts of dust generated by sections treated with various chemical dust palliatives. However, no system was employed to determine which products met a satisfactory level of control for users. Therefore, future studies should incorporate some means of determining empirical information based on user opinions. 


\section{REFERENCES}

Bergeson, K.L.; Brocka, S.G. 1996. Bentonite Treatment for Fugitive Dust Control. Proceedings of the 1996 Semisesquicentennial Transportation Conference, Ames, IA.

Bolander, P. (1997). Chemical additives for dust control: what we have used and what we have learned. Transportation Research Record: Journal of the Transportation Research Board, 1589, 42-49.

Bolander, P., and Yamada, A. (1999). Dust palliative selection and application guide. Project Report 9977-1207-SDTDC. San Dimas, CA: USDA San Dimas Technology and Development Center.

Chow, J. C., Watson, J. G., Ashbaugh, L. L., \& Magliano, K. L. (2003) Similarities and differences in PM10 chemical source profiles for geological dust from the San Joaquin Valley, California. Atmospheric Environment, 37, 1317-1340.

Cornell Local Roads Program. (1996) Basics of a Good Road. Ithica, NY.

Cowherd, C, Muleski, G.E., Englehart, P., Kinsey, J.S., \& Rosbury, K.D. (1990). Control of fugitive and hazardous dusts. Kansas City, Missouri: Noyes Data Corporation.

Das, B.M. (2006). Principles of Geotechnical Engineering, 5th edition. Toronto, Ontario, Canada: Thomson.

Das, B.M. (2007). Principles of Foundation Engineering, Adapted International Student Edition. Toronto, Ontario, Canada: Thomson

Federal Highway Administration (FHWA). (2001a) Planning for Transportation in Rural Areas, U.S. DOT Washington D.C.

Federal Highway Administration (FHWA), (2001b) Dust control on low volume roads: a review of techniques and chemicals used. Report No. FHWA-LT-01-002.

Ferguson, J.H., Down, H.W., Pfost, D.L. (1999) Fugitive Dust: Nonpoint Sources. Document No. G 1885. Agricultural MU Guide. MU Extension, University of Missouri-Columbia.

Freeman, G.E., and Fischenich, J.C. (2000) Gabions for streambank erosion control. Document No. EDRC TN-EMRRP SR-22. Ecosystem Management and Restoration Research Program

Gebhart, D.L., Hale, T.A., \& Michaels-Busch, K. (1996). Dust control material performance on unsurfaced roadways and tank trails. USAEC/USACERL Technical Report.

Gillies, J.A., Watson, J.G., Rogers, C.F., Dubois, D., Chow, J.C., Langston R., Sweet, J. (1999) Long term efficiencies of dust suppressants to reduce $\mathrm{PM}_{10}$ emissions from unpaved roads. Journal of the Air and Waste Management Association, 49, 3-16.

Giummarra, G.J., Foley, G., \& Stephen, C. (1997). Dust control: Australasian experiences with various chemical additives. Transportation Research Record, 1589, 50-53.

Gravel-PASER Manual. (2002). Pavement Surface Evaluation and Rating. Transportation Information Center, University ofWisconsin-Madison.

Harkin, J.M. (1969). Lignin and its uses. Document No. FPL-0206. U.S.D.A. Forest Service Research Note.

Huang, Yang. (2004). Pavement Analysis and Design. Prentice Hall.

Johnson, E.N., \& Olson, R.C. (2009). Minnesota Department of Transportation, Office of Materials. Best Practices for dust control on aggregate roads (MN/RC 2009-04). Springfield, VA: National Technical Information Services. 
Mamlouk, M.S., and Zaniewski, J.P. (2011). Materials for Civil and Construction Engineers. Pearson Education.

Mohamed, A.M., \& El Bassouni, K.M. (2007). Externalities of fugitive dust. Environmental Monitoring and Assessment, 130, 83-98.

Morgan, R.J., Schaefer, V.R., \& Sharma, R.S. (2005). Iowa Department of Transportation Highway Division and the Iowa Highway Reasarch Board, Determination and evaluation of alternative methods for managing and controlling highway-related dust; Phase II- demonstration project (IHRB Project TR506). Ames, IA

Oscarsson, K. (2007). Dust Suppressants for Nordic gravel roads (Licentiate thesis). KTH, Stockholm, Sweden.

Piechota, T., van Ee, J., Batista, J., Stave, K., \& James, D. (2004). U.S. Environmental Protection Agency, Office of Research and Development, National Exposure Research Laboratory, Environmental Sciences Division. Potential environmental impacts of dust suppressants: "avoiding another times beach" (EPA/600/R-04/031)

Rushing, J.F., Harrison, A., Tingle, J.S., Mason, Q., \& McCaffrey, T. (2006). Evaluation of dust palliatives for unpaved roads in arid climates. Journal of Performance of Constructed Facilities, 20(3), 281-286.

Rushing, J.F., \& Newman, K. (2009). Full-scale testing of chemical dust palliatives in a semicontrolled environment. Journal of Materials in Civil Engineering, 21(9), 454-459.

Sanders, T.G., Addo, J.Q., Ariniello, A., \& Heiden, W.F. (1997). Relative effectiveness of road dust suppressants. Journal of Transportation Engineering, 123(5), 393-397.

Sanders, T.G., \& Addo, J.Q. (2000). Experimental road dust measurement device. Journal of Transportation Engineering, 126(6), 530-535.

Skorseth, K., and Selim, A.A. (2000). Gravel Roads Maintenance and Design Manual. Federal Highway Administration.

Stewart, R. (2008). Our ocean planet: environmental geoscience in the $21^{\text {st }}$ century Retrieved from http://oceanworld.tamu.edu/resources/environment-book/contents.html

Swap, R., Garstang, M., Greco, S., Talbot, R., \& Kallberg, P. (1992). Saharan dust in the Amazon Basin. Tellus, 44B, 133-149

Thompson R.J. and Visser A.T. (2007). "Selection, performance and economic evaluation of dust palliatives on surface mine haul roads". The Journal of the Southern African Institute of Mining and Metallurgy. 107, pp. 435-450.

United States Environmental Protection Agency (U.S. EPA). (1992). 40 CFR parts 260, 261, 266, 271 and 279: hazardous waste management system; identification and standards. Retrieved September 9, 2010, from http://www.epa.gov/osw/conserve/materials/usedoil/fr/fr091092.txt

United States Environmental Protection Agency (U.S. EPA). (1995). Compilation of Air Pollutant Emission Factors, Volume 1: Stationary Point and Area Sources, AP-42, Fifth Edition, U.S.

Environmental Protection Agency, Office of Air Quality Planning and Standards, Research Triangle Park, North Carolina.

United States Environmental Protection Agency (U.S. EPA). Particulate Matter: Air Emission Sources. Retrieved April 12, 2010, from http://www.epa.gov/air/emissions/pm.htm

United States Environmental Protection Agency (U.S. EPA). PM10 NAAQS implementation. Retrieved March 12, 2010, from http://www.epa.gov/ttn/naaqs/pm/pm10_index.html 
Watson, J.G. (1996). Effectiveness Demonstration of fugitive dust control methods for public unpaved roads and unpaved shoulders on paved roads. Document No. 685-5200.1F1. Desert Research Institute, Reno, NV.

West Virginia Division of Highways (WVDOH). (2000). Section 300- Bases: Standard Specifications for Roads and Bridges

West Virginia Department of Transportation (WVDOT). (2003). 2003 West Virginia Crash Data, 14 
APPENDIX A GRAVEL ROAD INVENTORY DATA COLLECTION FORM FOR OAK GROVE ROAD 
WV LTAP

District 3

West Virginia DOH

Gravel Road Inventory Data Collection Form

Date: $5 / 19 / 10 \quad$ Completed by: $\angle B$

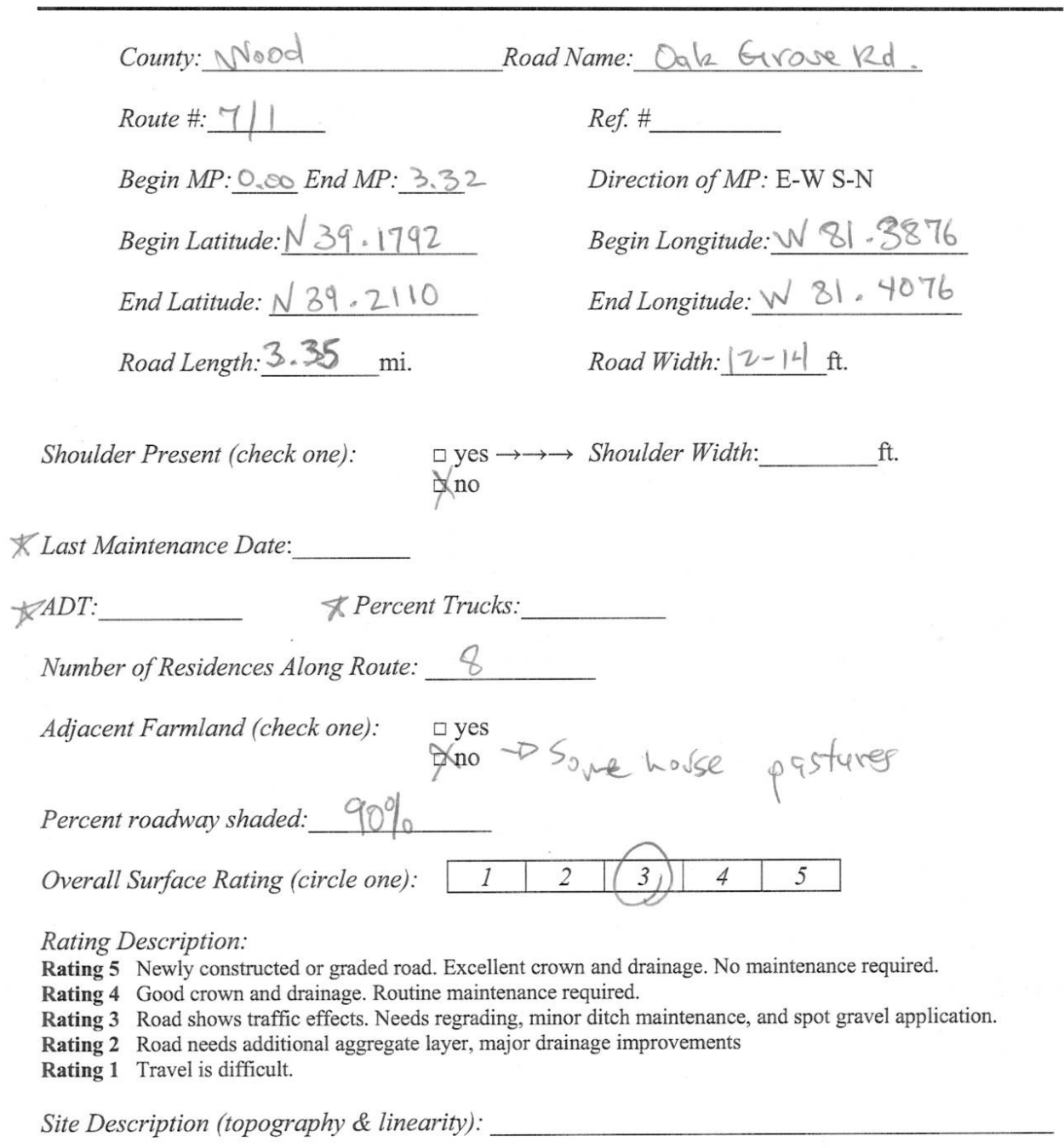

Figure A.1 Gravel Road Inventory Data Collection Form for Oak Grove Road 
APPENDIX B GRAVEL ROAD CONDITION SURVEYS FOR OAK GROVE ROAD 
WV LTAP

West Virginia DOH

Gravel Road Condition Survey

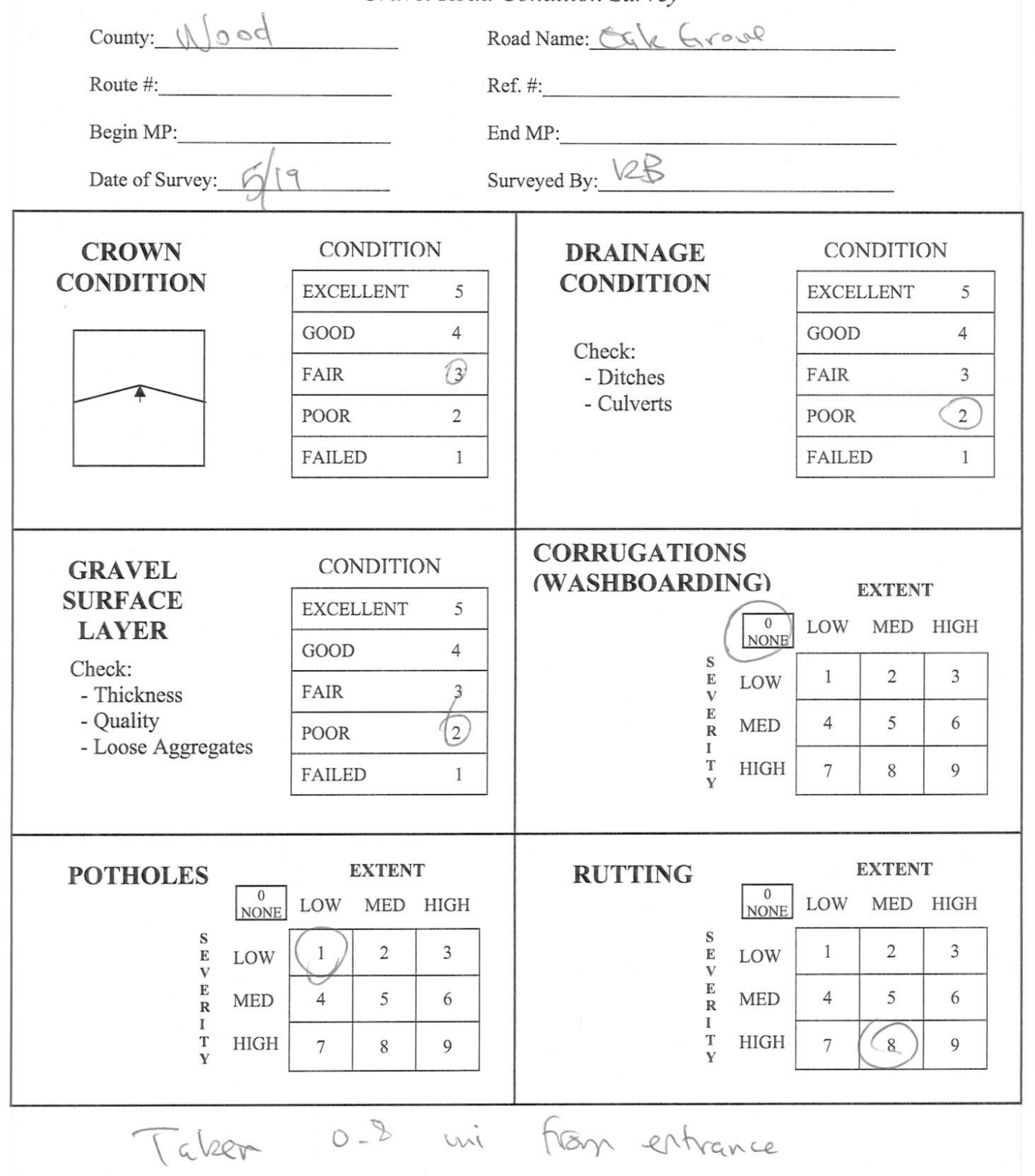

Figure B.1 Gravel Road Condition Survey of Oak Grove Road at MP 0.80 
WV LTAP

West Virginia DOH

Gravel Road Condition Survey

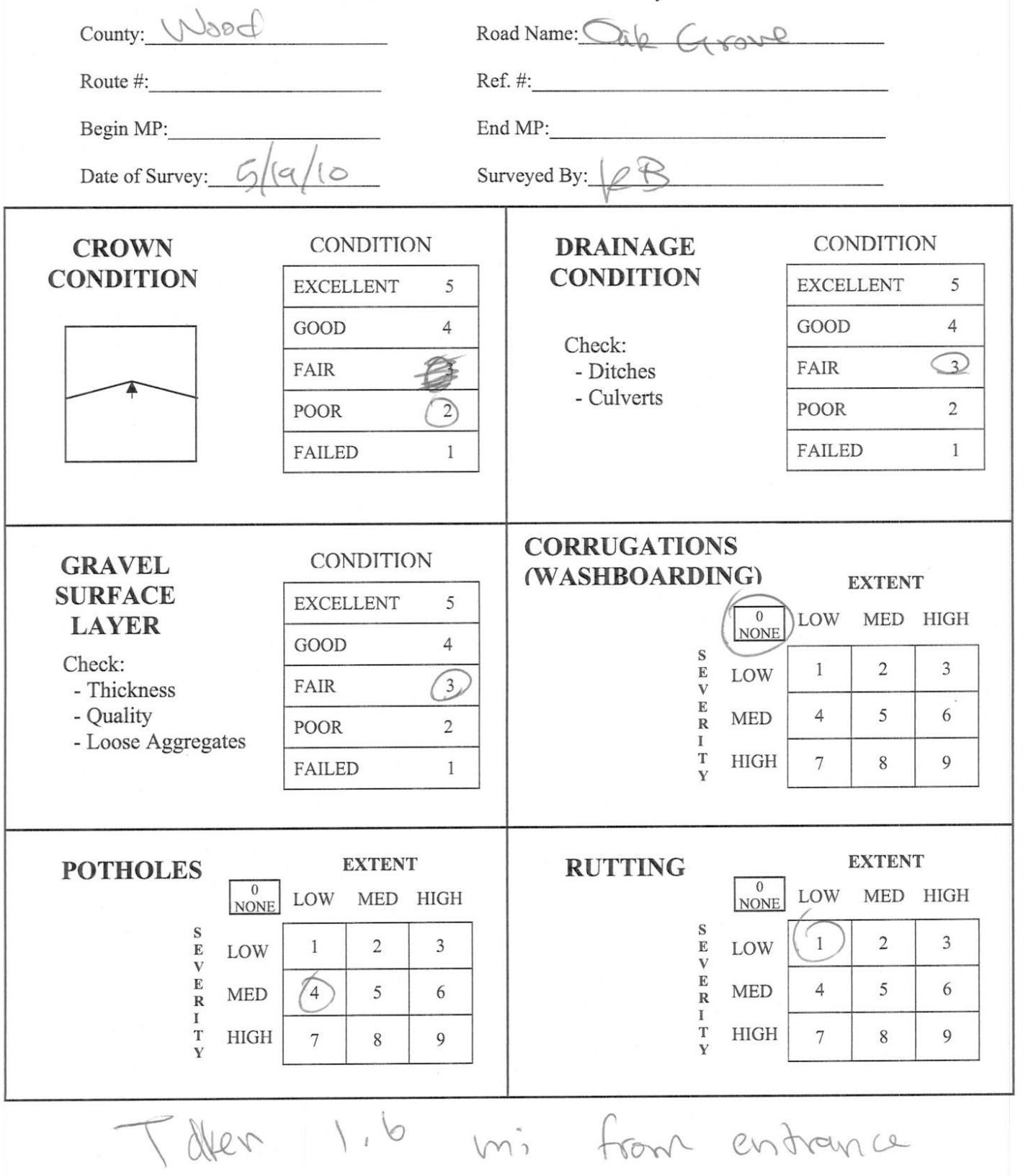

Figure B.2 Gravel Road Condition Survey of Oak Grove Road at MP 1.60 
WV LTAP

West Virginia DOH

Gravel Road Condition Survey

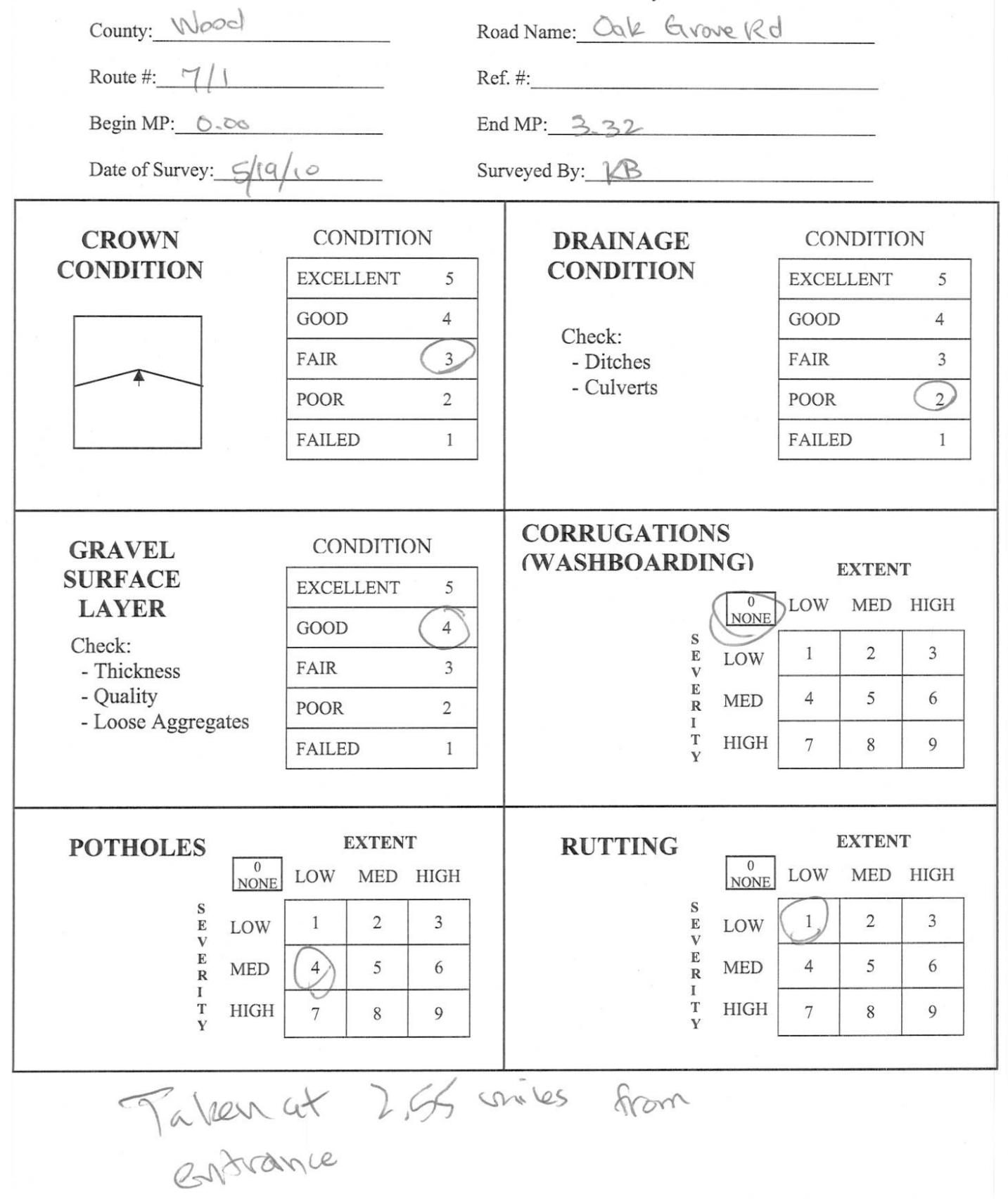

Figure B.3 Gravel Road Condition Survey of Oak Grove Road at MP 2.55 
APPENDIX C ACTIVITY LOG DURING PRODUCT EVALUATION PERIOD 


\begin{tabular}{|c|c|c|}
\hline Date & Activity & Observations \\
\hline $6 / 28 / 2010$ & $\begin{array}{l}\text { Calcium chloride } \\
\text { applied at 9:00 am }\end{array}$ & $\begin{array}{l}\text { - } \\
\text { - } \\
\text { - The fluid was clear and very sticky immediately } \\
\text { after application } \\
\text { - Soaked into road surface within one hour after } \\
\text { application }\end{array}$ \\
\hline $6 / 28 / 2010$ & $\begin{array}{l}\text { Petrotac and } \\
\text { TechSuppress applied } \\
\text { at 10:00 am (initial } \\
\text { applications) }\end{array}$ & $\begin{array}{l}\text { - Application rates were } 0.214 \text { and } 0.214 \mathrm{gal} / \mathrm{yd}^{2} \text {, } \\
\text { respectively } \\
\text { - Seven passes of Petrotac and six passes of } \\
\text { Techsuppress were required by distributor truck to } \\
\text { achieve desired application rate } \\
\text { - Petrotac hardened within eight hours, however few } \\
\text { tacky areas remained } \\
\text { - Techsuppress still tacky and uncured after eight } \\
\text { hours } \\
\text { - Techsuppress pooled in areas with potholes and } \\
\text { received complaints from passing motorists }\end{array}$ \\
\hline $6 / 29 / 2010$ & $\begin{array}{l}\text { Follow-up applications } \\
\text { of Petrotac and } \\
\text { TechSuppress } \\
\text { performed at 8:00 am }\end{array}$ & $\begin{array}{l}\text { - Application rates were } 0.086 \text { and } 0.064 \mathrm{gal} / \mathrm{yd}^{2} \text {, } \\
\text { respectively } \\
\text { - Five passes of each product were required by } \\
\text { distributor truck to achieve desired application rate }\end{array}$ \\
\hline $6 / 30 / 2010$ & $\begin{array}{l}\text { EK35 and Dust Fyghter } \\
\text { applied at 10:00 am }\end{array}$ & $\begin{array}{l}\text { - Application rates were } 0.14 \text { and } 0.32 \mathrm{gal} / \mathrm{yd}^{2}, \\
\text { respectively } \\
\text { - } \quad \text { Both products were reddish-brown in color } \\
\text { - } \quad \text { Two passes were required for each product to } \\
\text { achieve desired application rates }\end{array}$ \\
\hline $6 / 30 / 2010$ & $\begin{array}{l}\text { Check up on other } \\
\text { products }\end{array}$ & $\begin{array}{l}\text { - Calcium chloride section appears wet despite the dry } \\
\text { conditions, as though the road was just rained on } \\
\text { - TechSuppress still not fully cured and remained } \\
\text { pooled in areas with potholes } \\
\text { - Petrotac significantly hardened, however still tacky } \\
\text { in isolated areas }\end{array}$ \\
\hline $7 / 1 / 2010$ & $\begin{array}{l}\text { Check up on all } \\
\text { products }\end{array}$ & $\begin{array}{l}\text { - All products except calcium chloride still slightly } \\
\text { tacky in isolated areas } \\
\text { - Calcium chloride section still appeared wet } \\
\text { - Representatives from SynTech Products placed } \\
\text { absorbent material in potholes on section treated } \\
\text { with TechSuppress and distributed bottles of solvent } \\
\text { to residents who complained about product sticking }\end{array}$ \\
\hline
\end{tabular}




\begin{tabular}{|c|c|c|}
\hline & & to vehicles \\
\hline $7 / 6 / 2010$ & $\begin{array}{l}\text { Check up on all } \\
\text { products }\end{array}$ & $\begin{array}{l}\text { - Calcium chloride treated section still looked wet } \\
\text { - Petrotac and TechSuppress fully cured on roadway } \\
\text { - } \text { EK35 no longer tacky } \\
\text { - Dust Fyghter treated section looked very hard, } \\
\text { almost as though the product had been baked onto } \\
\text { the surface }\end{array}$ \\
\hline $7 / 8 / 2010$ & Day 8 data collection & $\begin{array}{l}\text { - Dust collection scheduled for all sections with } \\
\text { fabricated filter box } \\
\text { - Only } 22 \text { of } 27 \text { dust samples obtained due to } \\
\text { malfunction of filter box } \\
\text { - Silt load samples obtained for all sections }\end{array}$ \\
\hline $7 / 15 / 2010$ & Day 15 data collection & $\begin{array}{l}\text { - Dust samples obtained for all sections with } \\
\text { fabricated filter box } \\
\text { - Silt load samples obtained for all sections }\end{array}$ \\
\hline $7 / 28 / 2010$ & $\begin{array}{l}\text { Day } 28 \text { data collection } \\
\text { and check up on all } \\
\text { products }\end{array}$ & $\begin{array}{l}\text { - } \text { Dust samples obtained for all sections with } \\
\text { - } \text { fabricated filter box } \\
\text { - } \text { Calcium chloride showed little signs of deterioration } \\
\text { with no potholes developed } \\
\text { - Petrotac displayed little deterioration } \\
\text { - TechSuppress showed moderate signs of } \\
\text { - } \text { - EK35 showed significant signs of deterioration } \\
\text { - } \text { Dust Fyghter showed significant signs of } \\
\text { deterioration }\end{array}$ \\
\hline $8 / 30 / 2010$ & $\begin{array}{l}\text { Day } 61 \text { data collection } \\
\text { and check up on all } \\
\text { products }\end{array}$ & 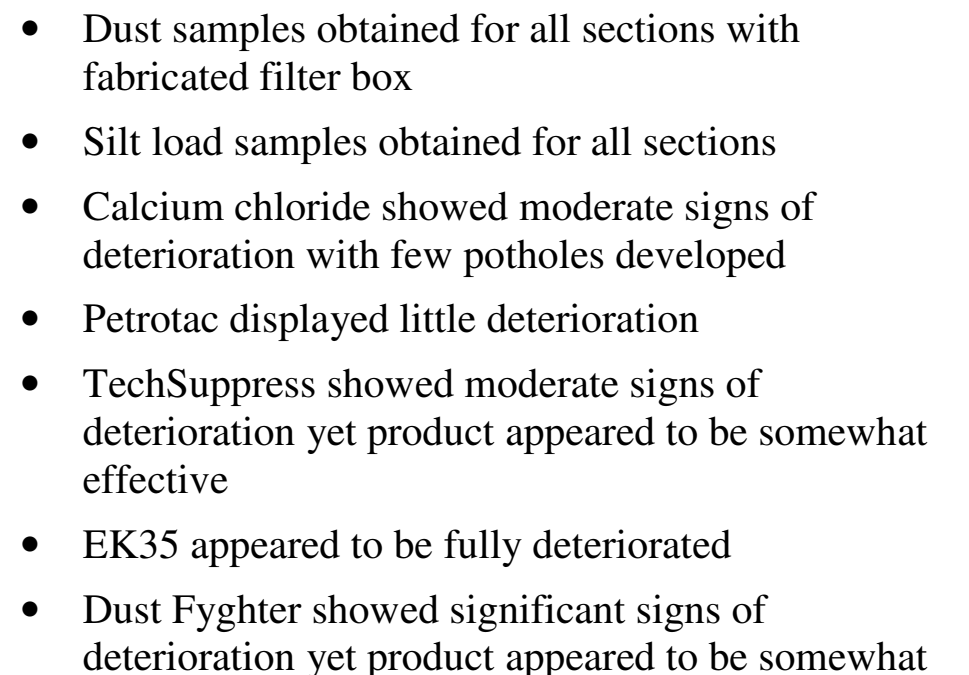 \\
\hline
\end{tabular}




\begin{tabular}{|c|c|c|}
\hline & & effective \\
\hline $10 / 11 / 2010$ & $\begin{array}{c}\text { Day } 103 \text { data collection } \\
\text { and check up on all } \\
\text { products }\end{array}$ & $\begin{array}{l}\text { Petrotac section looked as though some product still } \\
\text { remained. The greatest deterioration has occurred in } \\
\text { the wheel paths } \\
\text { - EK35 looked completely deteriorated } \\
\text { - Calcium chloride section looked as though the } \\
\text { surface color was darker than the adjacent untreated } \\
\text { control, possibly indicating that some product still } \\
\text { remained } \\
\text { - TechSuppress section looked significantly } \\
\text { deteriorated. Since the 61-day visit, WVDOH spread } \\
\text { fresh gravel into isolated areas where potholes had } \\
\text { formed } \\
\text { - Dust Fyghter product still seemed to be present in } \\
\text { areas with good drainage. In areas with poor } \\
\text { drainage, the product looked to be completely } \\
\text { deteriorated } \\
\text { - Control section 1,2, and } 3 \text { appeared highly } \\
\text { compacted with very little loose fines } \\
\text { Control } 4 \text { appeared very dusty with high fine content }\end{array}$ \\
\hline
\end{tabular}


APPENDIX D WEATHER OBSERVATIONS DURING PRODUCT EVALUATION PERIOD 


\begin{tabular}{|c|c|c|c|c|c|c|}
\hline Date & $\begin{array}{l}\text { Precipitation } \\
\text { (in.) }\end{array}$ & $\begin{array}{l}\text { Max. Temp } \\
\quad\left({ }^{\circ} \mathrm{F}\right)\end{array}$ & $\begin{array}{l}\text { Min. Temp } \\
\quad\left({ }^{\circ} \mathrm{F}\right)\end{array}$ & $\begin{array}{c}\text { Mean Wind } \\
\text { Speed } \\
\text { (knots) }\end{array}$ & $\begin{array}{c}\text { Dew Point } \\
\left({ }^{\circ} \mathrm{F}\right)\end{array}$ & $\begin{array}{c}\text { Relative } \\
\text { Humidity } \\
\text { (\%) }\end{array}$ \\
\hline $6 / 21 / 2010$ & 0.00 & 89.1 & 63.0 & 0.5 & 64.9 & 85.3 \\
\hline $6 / 22 / 2010$ & 0.00 & 87.1 & 69.1 & 4.2 & 68.0 & 87.1 \\
\hline $6 / 23 / 2010$ & 0.00 & 90.0 & 69.1 & 3.5 & 70.5 & 88.6 \\
\hline $6 / 24 / 2010$ & 0.00 & 87.1 & 71.1 & 6.2 & 69.7 & 88.1 \\
\hline $6 / 25 / 2010$ & 0.00 & 84.9 & 64.0 & 1.1 & 62.1 & 83.4 \\
\hline $6 / 26 / 2010$ & 0.00 & 89.1 & 62.1 & 2.6 & 64.1 & 84.8 \\
\hline $6 / 27 / 2010$ & 0.02 & 91.9 & 73.9 & 6.5 & 70.0 & 84.4 \\
\hline 6/28/2010 & 0.92 & 82.9 & 69.1 & 7.2 & 68.6 & 90.3 \\
\hline 6/29/2010 & 0.84 & 82.0 & 64.9 & 3.4 & 63.6 & 86.6 \\
\hline 6/30/2010 & 0.00 & 77.0 & 53.1 & 3.4 & 51.6 & 79.3 \\
\hline $7 / 1 / 2010$ & 0.00 & 77.0 & 48.9 & 2.9 & 48.3 & 76.7 \\
\hline $7 / 2 / 2010$ & 0.00 & 79.0 & 50.0 & 1.5 & 50.2 & 77.8 \\
\hline $7 / 3 / 2010$ & 0.10 & 86.0 & 51.8 & 1.0 & 54.9 & 79.7 \\
\hline $7 / 4 / 2010$ & 0.00 & 90.0 & 60.1 & 2.0 & 62.7 & 83.5 \\
\hline $7 / 5 / 2010$ & 0.00 & 91.0 & 66.2 & 1.2 & 68.1 & 86.6 \\
\hline $7 / 6 / 2010$ & 0.00 & 93.9 & 68.0 & 1.4 & 67.4 & 83.3 \\
\hline $7 / 7 / 2010$ & 0.00 & 93.9 & 68.0 & 1.7 & 67.9 & 83.9 \\
\hline $7 / 8 / 2010$ & 0.00 & 93.0 & 66.2 & 1.5 & 67.8 & 85.2 \\
\hline $7 / 9 / 2010$ & 0.00 & 82.0 & 69.8 & 1.9 & 71.1 & 93.7 \\
\hline $7 / 10 / 2010$ & 0.47 & 86.0 & 66.2 & 3.6 & 65.2 & 85.7 \\
\hline $7 / 11 / 2010$ & 0.01 & 87.1 & 62.1 & 1.0 & 62.8 & 84.2 \\
\hline $7 / 12 / 2010$ & 0.00 & 82.9 & 66.9 & 2.4 & 66.4 & 88.7 \\
\hline $7 / 13 / 2010$ & 1.62 & 78.1 & 69.8 & 1.8 & 70.7 & 95.6 \\
\hline $7 / 14 / 2010$ & 0.73 & 82.9 & 66.2 & 2.3 & 68.2 & 91.5 \\
\hline $7 / 15 / 2010$ & 0.01 & 87.1 & 64.4 & 1.5 & 68.9 & 91.0 \\
\hline $7 / 16 / 2010$ & 0.18 & 84.9 & 68.0 & 2.3 & 71.3 & 93.3 \\
\hline $7 / 17 / 2010$ & 0.01 & 86.0 & 69.8 & 3.7 & 69.9 & 89.7 \\
\hline $7 / 18 / 2010$ & 0.69 & 88.0 & 69.1 & 4.5 & 69.7 & 88.7 \\
\hline $7 / 19 / 2010$ & 0.96 & 84.9 & 68.0 & 4.5 & 69.1 & 90.4 \\
\hline $7 / 20 / 2010$ & 0.40 & 82.9 & 69.8 & 3.4 & 70.0 & 91.7 \\
\hline $7 / 21 / 2010$ & 0.01 & 84.9 & 72.0 & 4.6 & 71.4 & 91.0 \\
\hline $7 / 22 / 2010$ & 0.00 & 87.1 & 71.6 & 2.7 & 71.5 & 90.1 \\
\hline $7 / 23 / 2010$ & 0.00 & 91.0 & 75.0 & 5.8 & 73.1 & 88.1 \\
\hline
\end{tabular}




\begin{tabular}{|c|c|c|c|c|c|c|}
\hline Date & $\begin{array}{l}\text { Precipitation } \\
\text { (in.) }\end{array}$ & $\begin{array}{l}\text { Max. Temp } \\
\quad\left({ }^{\circ} \mathrm{F}\right)\end{array}$ & $\begin{array}{l}\text { Min. Temp } \\
\left({ }^{\circ} \mathrm{F}\right)\end{array}$ & $\begin{array}{c}\text { Mean Wind } \\
\text { Speed } \\
\text { (knots) }\end{array}$ & $\begin{array}{c}\text { Dew Point } \\
\left({ }^{\circ} \mathrm{F}\right)\end{array}$ & $\begin{array}{c}\text { Relative } \\
\text { Humidity } \\
\text { (\%) }\end{array}$ \\
\hline $7 / 24 / 2010$ & 0.00 & 91.0 & 75.9 & 7.0 & 71.5 & 85.7 \\
\hline $7 / 25 / 2010$ & 0.00 & 87.1 & 73.0 & 5.1 & 71.4 & 89.2 \\
\hline $7 / 26 / 2010$ & 0.16 & 84.9 & 64.9 & 2.4 & 63.7 & 85.0 \\
\hline $7 / 27 / 2010$ & 0.00 & 86.0 & 62.1 & 0.7 & 61.8 & 83.5 \\
\hline $7 / 28 / 2010$ & 0.00 & 87.1 & 66.0 & 3.0 & 68.5 & 89.5 \\
\hline $7 / 29 / 2010$ & 0.00 & 84.2 & 75.2 & 5.1 & 70.8 & 88.8 \\
\hline $7 / 30 / 2010$ & 0.00 & 81.0 & 57.2 & 1.4 & 57.8 & 83.6 \\
\hline $7 / 31 / 2010$ & 0.00 & 82.9 & 66.0 & 1.7 & 63.9 & 85.8 \\
\hline $8 / 1 / 2010$ & 0.05 & 79.0 & 64.4 & 0.5 & 65.5 & 91.4 \\
\hline $8 / 4 / 2010$ & 0.00 & 90.0 & 71.6 & 6.7 & 72.1 & 89.2 \\
\hline $8 / 5 / 2010$ & 0.23 & 84.9 & 70.0 & 3.5 & 70.5 & 91.0 \\
\hline $8 / 6 / 2010$ & 0.01 & 82.9 & 68.0 & 3.9 & 65.5 & 86.8 \\
\hline $8 / 7 / 2010$ & 0.01 & 84.9 & 59.0 & 1.4 & 59.5 & 82.7 \\
\hline $8 / 8 / 2010$ & 0.01 & 88.0 & 60.1 & 1.3 & 60.5 & 81.7 \\
\hline 8/9/2010 & 0.02 & 91.9 & 62.1 & 1.0 & 64.2 & 83.4 \\
\hline $8 / 10 / 2010$ & 0.01 & 91.0 & 68.0 & 1.7 & 70.2 & 88.3 \\
\hline $8 / 11 / 2010$ & 0.29 & 89.1 & 73.4 & 1.6 & 74.4 & 91.6 \\
\hline $8 / 12 / 2010$ & 0.12 & 90.0 & 71.1 & 3.3 & 71.1 & 88.3 \\
\hline $8 / 13 / 2010$ & 0.01 & 90.0 & 71.6 & 2.2 & 71.5 & 88.5 \\
\hline $8 / 14 / 2010$ & 0.00 & 93.0 & 73.0 & 4.1 & 71.3 & 85.9 \\
\hline $8 / 15 / 2010$ & 0.31 & 88.0 & 73.0 & 3.7 & 72.3 & 89.8 \\
\hline $8 / 16 / 2010$ & 0.00 & 87.1 & 73.0 & 3.5 & 67.6 & 84.4 \\
\hline $8 / 17 / 2010$ & 0.01 & 86.0 & 57.2 & 1.0 & 57.9 & 80.9 \\
\hline $8 / 18 / 2010$ & 0.00 & 82.0 & 60.1 & 0.4 & 60.5 & 85.2 \\
\hline $8 / 19 / 2010$ & 0.01 & 88.0 & 60.8 & 1.0 & 62.4 & 83.9 \\
\hline $8 / 20 / 2010$ & 0.01 & 89.1 & 62.6 & 1.3 & 64.9 & 85.6 \\
\hline $8 / 21 / 2010$ & 0.30 & 86.0 & 66.9 & 4.9 & 68.1 & 89.1 \\
\hline $8 / 22 / 2010$ & 0.17 & 81.0 & 71.1 & 5.0 & 68.7 & 90.3 \\
\hline $8 / 23 / 2010$ & 0.00 & 80.1 & 62.1 & 3.4 & 64.4 & 90.6 \\
\hline $8 / 24 / 2010$ & 0.00 & 80.1 & 64.0 & 4.1 & 62.3 & 86.5 \\
\hline $8 / 25 / 2010$ & 0.01 & 84.0 & 62.6 & 2.6 & 62.9 & 85.8 \\
\hline $8 / 26 / 2010$ & 0.00 & 82.0 & 60.1 & 2.0 & 60.1 & 84.6 \\
\hline $8 / 27 / 2010$ & 0.00 & 82.9 & 55.9 & 2.5 & 55.3 & 79.7 \\
\hline
\end{tabular}




\begin{tabular}{|c|c|c|c|c|c|c|}
\hline Date & $\begin{array}{l}\text { Precipitation } \\
\text { (in.) }\end{array}$ & $\begin{array}{l}\text { Max. Temp } \\
\quad\left({ }^{\circ} \mathrm{F}\right)\end{array}$ & $\begin{array}{l}\text { Min. Temp } \\
\quad\left({ }^{\circ} \mathrm{F}\right)\end{array}$ & $\begin{array}{c}\text { Mean Wind } \\
\text { Speed } \\
\text { (knots) }\end{array}$ & $\begin{array}{c}\text { Dew Point } \\
\left({ }^{\circ} \mathrm{F}\right)\end{array}$ & $\begin{array}{c}\text { Relative } \\
\text { Humidity } \\
\text { (\%) }\end{array}$ \\
\hline $8 / 28 / 2010$ & 0.00 & 87.1 & 53.6 & 1.6 & 55.8 & 79.3 \\
\hline $8 / 29 / 2010$ & 0.01 & 91.0 & 57.0 & 0.7 & 59.2 & 80.0 \\
\hline $8 / 30 / 2010$ & 0.01 & 93.0 & 62.1 & 1.0 & 63.6 & 82.0 \\
\hline $8 / 31 / 2010$ & 0.00 & 91.9 & 62.6 & 1.6 & 64.3 & 83.2 \\
\hline $9 / 1 / 2010$ & 0.00 & 91.9 & 62.6 & 2.6 & 62.5 & 80.9 \\
\hline $9 / 2 / 2010$ & 0.00 & 93.0 & 62.1 & 2.4 & 60.5 & 78.0 \\
\hline $9 / 3 / 2010$ & 0.00 & 86.0 & 60.1 & 5.8 & 61.2 & 83.8 \\
\hline $9 / 4 / 2010$ & 0.01 & 75.9 & 57.9 & 9.4 & 46.5 & 69.5 \\
\hline $9 / 5 / 2010$ & 0.00 & 75.0 & 45.0 & 1.8 & 43.7 & 72.8 \\
\hline $9 / 6 / 2010$ & 0.00 & 86.0 & 46.0 & 2.3 & 46.5 & 70.5 \\
\hline $9 / 7 / 2010$ & 0.00 & 91.9 & 57.0 & 5.5 & 55.4 & 74.4 \\
\hline $9 / 8 / 2010$ & 0.00 & 84.0 & 64.0 & 9.2 & 51.5 & 69.6 \\
\hline $9 / 9 / 2010$ & 0.00 & 73.9 & 48.0 & 2.5 & 47.6 & 78.1 \\
\hline 9/10/2010 & 0.00 & 75.9 & 44.6 & 1.9 & 46.7 & 77.5 \\
\hline $9 / 11 / 2010$ & 0.00 & 79.0 & 46.9 & 3.9 & 52.0 & 82.6 \\
\hline $9 / 12 / 2010$ & 0.00 & 78.1 & 60.8 & 4.9 & 55.6 & 80.1 \\
\hline 9/13/2010 & 0.00 & 86.0 & 48.9 & 3.7 & 52.6 & 78.0 \\
\hline 9/14/2010 & 0.14 & 78.1 & 54.0 & 2.0 & 52.8 & 79.9 \\
\hline $9 / 15 / 2010$ & 0.00 & 84.0 & 48.0 & 1.1 & 49.5 & 75.0 \\
\hline $9 / 16 / 2010$ & 0.00 & 73.0 & 60.1 & 6.1 & 59.9 & 90.0 \\
\hline $9 / 17 / 2010$ & 0.65 & 73.0 & 60.1 & 3.6 & 56.4 & 84.7 \\
\hline $9 / 18 / 2010$ & 0.02 & 82.0 & 50.0 & 0.7 & 52.2 & 79.1 \\
\hline 9/19/2010 & 0.00 & 84.9 & 55.9 & 1.4 & 55.7 & 79.1 \\
\hline $9 / 20 / 2010$ & 0.00 & 81.0 & 60.1 & 41.0 & 54.0 & 76.5 \\
\hline $9 / 21 / 2010$ & 0.00 & 88.0 & 52.0 & 2.6 & 55.9 & 79.9 \\
\hline $9 / 22 / 2010$ & 0.00 & 93.0 & 64.9 & 4.5 & 62.2 & 78.8 \\
\hline $9 / 23 / 2010$ & 0.35 & 91.0 & 62.6 & 2.3 & 63.7 & 82.9 \\
\hline $9 / 24 / 2010$ & 0.01 & 91.0 & 70.0 & 7.4 & 59.9 & 74.4 \\
\hline $9 / 25 / 2010$ & 0.05 & 84.9 & 59.0 & 6.5 & 55.7 & 77.4 \\
\hline $9 / 26 / 2010$ & 0.00 & 66.2 & 51.8 & 4.1 & 47.6 & 71.9 \\
\hline $9 / 27 / 2010$ & 0.24 & 66.2 & 55.4 & 2.8 & 54.9 & 90.3 \\
\hline $9 / 28 / 2010$ & 0.34 & 63.0 & 55.0 & 4.7 & 56.1 & 95.1 \\
\hline 9/29/2010 & 0.03 & 69.8 & 48.2 & 2.0 & 51.7 & 87.6 \\
\hline
\end{tabular}




\begin{tabular}{|c|c|c|c|c|c|c|}
\hline Date & $\begin{array}{c}\text { Precipitation } \\
\text { (in.) }\end{array}$ & $\begin{array}{c}\text { Max. Temp } \\
\left({ }^{\circ} \mathbf{F}\right)\end{array}$ & $\begin{array}{c}\text { Min. Temp } \\
\left({ }^{\circ} \mathrm{F}\right)\end{array}$ & $\begin{array}{c}\text { Mean Wind } \\
\text { Speed } \\
(\text { knots) }\end{array}$ & $\begin{array}{c}\text { Dew Point } \\
\left({ }^{\circ} \mathrm{F}\right)\end{array}$ & $\begin{array}{c}\text { Relative } \\
\text { Humidity } \\
(\%)\end{array}$ \\
\hline \hline $9 / 30 / 2010$ & 0.00 & 75.2 & 57.2 & 3.9 & 53.1 & 80.2 \\
\hline $10 / 1 / 2010$ & 0.00 & 69.1 & 50.0 & 4.9 & 47.7 & 80.1 \\
\hline $10 / 2 / 2010$ & 0.00 & 72.0 & 39.0 & 2.4 & 42.4 & 76.4 \\
\hline $10 / 3 / 2010$ & 0.06 & 59.0 & 48.0 & 3.2 & 45.6 & 85.2 \\
\hline $10 / 4 / 2010$ & 0.12 & 55.4 & 48.2 & 3.5 & 46.6 & 90.0 \\
\hline $10 / 5 / 2010$ & 0.04 & 53.1 & 46.0 & 3.3 & 45.0 & 90.8 \\
\hline $10 / 6 / 2010$ & 0.27 & 62.1 & 46.0 & 4.3 & 45.5 & 84.2 \\
\hline $10 / 7 / 2010$ & 0.01 & 72.0 & 51.1 & 5.7 & 43.0 & 69.9 \\
\hline $10 / 8 / 2010$ & 0.00 & 77.0 & 39.0 & 1.5 & 42.0 & 72.4 \\
\hline $10 / 9 / 2010$ & 0.00 & 82.0 & 42.1 & 1.3 & 44.1 & 71.1 \\
\hline $10 / 10 / 2010$ & 0.00 & 84.9 & 48.0 & 2.7 & 49.6 & 74.6 \\
\hline $10 / 11 / 2010$ & 0.00 & 84.0 & 50.0 & 2.7 & 48.6 & 72.5 \\
\hline
\end{tabular}


APPENDIX E DUST MEASUREMENT DATA 
Table E.1 Day-8 Dust Measurement Data

\begin{tabular}{|c|c|c|c|c|c|}
\hline & & \multicolumn{4}{|c|}{ Dust (g/mile) } \\
Section No. & Product Name & Run 1 & Run 2 & Run 3 & Average \\
\hline \hline 1 & PetroTac & 0.08 & 0.09 & & 0.09 \\
\hline 2 & Untreated 1 & 0.77 & 0.93 & & 0.85 \\
\hline 3 & EK 35 & 0.28 & 0.17 & 0.34 & 0.26 \\
\hline 4 & Untreated 2 & 0.99 & 1.01 & & 1.00 \\
\hline 5 & Calcium Chloride & 0.25 & 0.25 & 0.28 & 0.26 \\
\hline 6 & Untreated 3 & 0.84 & 1.08 & & 0.96 \\
\hline 7 & Tech Suppress & 0.26 & 0.14 & & 0.20 \\
\hline 8 & Untreated 4 & 1.44 & 1.33 & 1.85 & 1.54 \\
\hline 9 & Dust Fyghter & 0.12 & 0.10 & 0.11 & 0.11 \\
\hline
\end{tabular}

Table E.2 Day-15 Dust Measurement Data

\begin{tabular}{|c|c|c|c|c|c|}
\hline & & \multicolumn{4}{|c|}{ Dust (g/mile) } \\
Section No. & Product Name & Run 1 & \multicolumn{1}{c|}{ Run 2 } & \multicolumn{1}{c|}{ Run 3 } & Average \\
\hline \hline 1 & PetroTac & 0.07 & 0.02 & 0.18 & 0.09 \\
\hline 2 & Untreated 1 & 0.22 & 0.26 & 0.25 & 0.24 \\
\hline 3 & EK 35 & 0.37 & 0.30 & 0.35 & 0.34 \\
\hline 4 & Untreated 2 & 0.35 & 0.41 & 0.29 & 0.35 \\
\hline 5 & Calcium Chloride & 0.20 & 0.21 & 0.22 & 0.21 \\
\hline 6 & Untreated 3 & 0.19 & 0.12 & 0.23 & 0.18 \\
\hline 7 & Tech Suppress & 0.18 & 0.14 & 0.13 & 0.15 \\
\hline 8 & Untreated 4 & 0.45 & 0.49 & 0.43 & 0.46 \\
\hline 9 & Dust Fyghter & 0.18 & 0.20 & 0.18 & 0.19 \\
\hline
\end{tabular}


Table E.3 Day-28 Dust Measurement Data

\begin{tabular}{|c|c|c|c|c|c|}
\hline & & \multicolumn{4}{|c|}{ Dust (g/mile) } \\
Section No. & Product Name & Run 1 & Run 2 & Run 3 & Average \\
\hline \hline 1 & PetroTac & 0.12 & 0.08 & 0.05 & 0.08 \\
\hline 2 & Untreated 1 & 0.84 & 0.68 & 0.58 & 0.70 \\
\hline 3 & EK 35 & 0.80 & 0.80 & 0.70 & 0.77 \\
\hline 4 & Untreated 2 & 0.71 & 0.88 & 0.77 & 0.79 \\
\hline 5 & Calcium Chloride & 0.50 & 0.40 & 0.37 & 0.42 \\
\hline 6 & Untreated 3 & 0.71 & 0.81 & 0.88 & 0.80 \\
\hline 7 & Tech Suppress & 0.49 & 0.31 & 0.30 & 0.37 \\
\hline 8 & Untreated 4 & 1.60 & 1.27 & 1.30 & 1.39 \\
\hline 9 & Dust Fyghter & 0.51 & 0.52 & 0.46 & 0.50 \\
\hline
\end{tabular}

Table E.4 Day-61 Dust Measurement Data

\begin{tabular}{|c|c|c|c|c|c|}
\hline & & \multicolumn{4}{|c|}{ Dust (g/mile) } \\
Section No. & Product Name & Run 1 & Run 2 & Run 3 & Average \\
\hline \hline 1 & PetroTac & 0.22 & 0.19 & 0.24 & 0.22 \\
\hline 2 & Untreated 1 & 0.98 & 1.04 & 1.52 & 1.18 \\
\hline 3 & EK 35 & 1.14 & 1.05 & 1.23 & 1.14 \\
\hline 4 & Untreated 2 & 1.04 & 1.27 & 1.35 & 1.22 \\
\hline 5 & Calcium Chloride & 0.93 & 1.12 & 1.11 & 1.05 \\
\hline 6 & Untreated 3 & 1.22 & 1.14 & 1.37 & 1.24 \\
\hline 7 & Tech Suppress & 0.85 & 0.74 & 1.28 & 0.96 \\
\hline 8 & Untreated 4 & 1.53 & 1.48 & 1.83 & 1.61 \\
\hline 9 & Dust Fyghter & 0.79 & 0.79 & 1.13 & 0.90 \\
\hline
\end{tabular}


Table E.5 Day-103 Dust Measurement Data

\begin{tabular}{|c|c|c|c|c|c|}
\hline & & \multicolumn{4}{|c|}{ Dust (g/mile) } \\
Section No. & Product Name & Run 1 & \multicolumn{1}{|c|}{ Run 2 } & \multicolumn{1}{c|}{ Run 3 } & Average \\
\hline \hline 1 & PetroTac & 0.12 & 0.13 & 0.13 & 0.13 \\
\hline 2 & Untreated 1 & 0.31 & 0.34 & 0.38 & 0.34 \\
\hline 3 & EK 35 & 0.43 & 0.57 & 0.65 & 0.55 \\
\hline 4 & Untreated 2 & 0.47 & 0.50 & 0.58 & 0.52 \\
\hline 5 & Calcium Chloride & 0.37 & 0.38 & 0.36 & 0.37 \\
\hline 6 & Untreated 3 & 0.39 & 0.42 & 0.41 & 0.41 \\
\hline 7 & Tech Suppress & 0.41 & 0.43 & 0.49 & 0.44 \\
\hline 8 & Untreated 4 & 0.45 & 0.32 & 0.78 & 0.52 \\
\hline 9 & Dust Fyghter & 0.34 & 0.37 & 0.30 & 0.34 \\
\hline
\end{tabular}




\section{APPENDIX F SOIL SILT FRACTIONS DATA}


Table F.1 Day-28 Silt Load Fractions

\begin{tabular}{|c|c|c|c|c|c|}
\hline \multirow{2}{*}{ Section No. } & \multirow{2}{*}{ Product Name } & \multicolumn{4}{|c|}{ Silt load $\left(\mathrm{g} / \mathrm{m}^{2}\right)$} \\
\cline { 3 - 6 } & & Sample 1 & Sample 2 & Sample 3 & Average \\
\hline 1 & PetroTac & 1.87 & 3.33 & 4.19 & 3.13 \\
\hline 2 & Untreated 1 & 209.41 & 404.44 & 222.58 & 278.81 \\
\hline 3 & EK 35 & 370.15 & 437.65 & 172.46 & 326.75 \\
\hline 4 & Untreated 2 & 129.80 & 221.15 & 178.28 & 176.41 \\
\hline 5 & Calcium Chloride & 146.39 & 73.67 & 113.59 & 111.21 \\
\hline 6 & Untreated 3 & 278.14 & 220.72 & 217.71 & 238.86 \\
\hline 7 & Tech Suppress & 17.98 & 57.13 & 52.08 & 42.40 \\
\hline 8 & Untreated 4 & 429.80 & 329.34 & 509.85 & 423.00 \\
\hline 9 & Dust Fyghter & 32.24 & 54.02 & 53.89 & 46.72 \\
\hline
\end{tabular}

Table F.2 Day-61 Silt Load Fractions

\begin{tabular}{|c|c|c|c|c|c|}
\hline \multirow{2}{*}{ Section No. } & \multirow{2}{*}{ Product Name } & \multicolumn{4}{|c|}{ Silt load $\left(\mathrm{g} / \mathrm{m}^{2}\right)$} \\
\cline { 3 - 6 } & & Sample 1 & Sample 2 & Sample 3 & Average \\
\hline 1 & PetroTac & 8.23 & 10.03 & 2.54 & 6.93 \\
\hline 2 & Untreated 1 & 208.74 & 799.28 & 706.03 & 571.35 \\
\hline 3 & EK 35 & 804.95 & 484.48 & 532.41 & 607.28 \\
\hline 4 & Untreated 2 & 618.10 & 701.72 & 552.48 & 624.10 \\
\hline 5 & Calcium Chloride & 241.76 & 359.18 & 308.91 & 303.29 \\
\hline 6 & Untreated 3 & 740.86 & 1368.24 & 475.76 & 861.62 \\
\hline 7 & Tech Suppress & 1281.82 & 552.94 & 501.08 & 778.61 \\
\hline 8 & Untreated 4 & 732.47 & 746.75 & 663.53 & 714.25 \\
\hline 9 & Dust Fyghter & 43.55 & 51.74 & 202.97 & 99.42 \\
\hline
\end{tabular}


Table F.3 Day-103 Silt Load Fractions

\begin{tabular}{|c|c|c|c|c|c|}
\hline \multirow{2}{*}{ Section No. } & \multirow{2}{*}{ Product Name } & \multicolumn{4}{|c|}{ Silt load $(\mathrm{g} / \mathrm{m} 2)$} \\
\cline { 3 - 6 } & & Sample 1 & Sample 2 & Sample 3 & Average \\
\hline 1 & PetroTac & 34.21 & 75.60 & 56.24 & 55.35 \\
\hline 2 & Untreated 1 & 45.24 & 29.71 & 26.02 & 33.66 \\
\hline 3 & EK 35 & 89.44 & 244.41 & 141.57 & 158.47 \\
\hline 4 & Untreated 2 & 89.59 & 217.88 & 211.36 & 172.94 \\
\hline 5 & Calcium Chloride & 66.46 & 109.07 & 76.61 & 84.05 \\
\hline 6 & Untreated 3 & 85.39 & 137.10 & 111.56 & 111.35 \\
\hline 7 & Tech Suppress & 195.85 & 213.40 & 226.88 & 212.04 \\
\hline 8 & Untreated 4 & 380.65 & 482.73 & 370.53 & 411.30 \\
\hline 9 & Dust Fyghter & 148.85 & 65.43 & 51.44 & 88.57 \\
\hline
\end{tabular}


APPENDIX G SOIL MOISTURE CONTENT DATA 
Table G.1 Day-8 Soil Moisture Contents

\begin{tabular}{|c|c|c|c|c|c|}
\hline & & \multicolumn{4}{|c|}{ Moisture Content (\%) } \\
Section No. & Product Name & Sample 1 & Sample 2 & Sample 3 & Average \\
\hline \hline 1 & PetroTac & 0.50 & 0.16 & 0.27 & 0.31 \\
\hline 2 & Untreated 1 & 0.13 & 0.14 & 0.29 & 0.19 \\
\hline 3 & EK 35 & 0.49 & 0.39 & 0.42 & 0.43 \\
\hline 4 & Untreated 2 & 0.31 & 0.33 & 0.38 & 0.34 \\
\hline 5 & Calcium Chloride & 1.59 & 1.89 & 1.58 & 1.69 \\
\hline 6 & Untreated 3 & 0.57 & 0.66 & 0.41 & 0.55 \\
\hline 7 & Tech Suppress & 1.00 & 1.08 & 0.47 & 0.85 \\
\hline 8 & Untreated 4 & 0.30 & 0.27 & 0.31 & 0.29 \\
\hline 9 & Dust Fyghter & 0.18 & 0.20 & 0.29 & 0.22 \\
\hline
\end{tabular}

Table G.2 Day-28 Soil Moisture Contents

\begin{tabular}{|c|c|c|c|c|c|}
\hline & & \multicolumn{4}{|c|}{ Moisture Content (\%) } \\
Section No. & Product Name & Sample 1 & Sample 2 & Sample 3 & Average \\
\hline \hline 1 & PetroTac & 0.36 & 0.28 & 1.10 & 0.58 \\
\hline 2 & Untreated 1 & 0.49 & 0.31 & 0.46 & 0.42 \\
\hline 3 & EK 35 & 0.39 & 0.33 & 0.36 & 0.36 \\
\hline 4 & Untreated 2 & 0.36 & 0.28 & 0.28 & 0.31 \\
\hline 5 & Calcium Chloride & 0.96 & 0.88 & 0.75 & 0.86 \\
\hline 6 & Untreated 3 & 0.43 & 0.44 & 0.30 & 0.39 \\
\hline 7 & Tech Suppress & 0.70 & 0.37 & 0.32 & 0.46 \\
\hline 8 & Untreated 4 & 0.15 & 0.19 & 0.17 & 0.17 \\
\hline 9 & Dust Fyghter & 0.14 & 0.20 & 0.15 & 0.16 \\
\hline
\end{tabular}


Table G.3 Day-61 Soil Moisture Contents

\begin{tabular}{|c|c|c|c|c|c|}
\hline & & \multicolumn{4}{|c|}{ Moisture Content (\%) } \\
Section No. & Product Name & Sample 1 & Sample 2 & Sample 3 & Average \\
\hline \hline 1 & PetroTac & 0.49 & 0.22 & 0.40 & 0.37 \\
\hline 2 & Untreated 1 & 1.17 & 0.43 & 0.63 & 0.74 \\
\hline 3 & EK 35 & 0.50 & 0.54 & 0.65 & 0.56 \\
\hline 4 & Untreated 2 & 0.38 & 0.39 & 0.28 & 0.35 \\
\hline 5 & Calcium Chloride & 1.03 & 0.81 & 1.00 & 0.95 \\
\hline 6 & Untreated 3 & 0.48 & 0.61 & 1.46 & 0.85 \\
\hline 7 & Tech Suppress & 0.23 & 0.50 & 0.28 & 0.34 \\
\hline 8 & Untreated 4 & 0.12 & 0.16 & 0.13 & 0.14 \\
\hline 9 & Dust Fyghter & 0.16 & 0.13 & 0.19 & 0.16 \\
\hline
\end{tabular}

Table G.4 Day-103 Soil Moisture Contents

\begin{tabular}{|c|c|c|c|c|c|}
\hline & & \multicolumn{4}{|c|}{ Moisture Content (\%) } \\
Section No. & Product Name & Sample 1 & Sample 2 & Sample 3 & Average \\
\hline \hline 1 & PetroTac & 0.65 & 0.33 & 0.52 & 0.50 \\
\hline 2 & Untreated 1 & 0.49 & 0.29 & 0.37 & 0.38 \\
\hline 3 & EK 35 & 0.65 & 0.43 & 0.56 & 0.55 \\
\hline 4 & Untreated 2 & 0.80 & 0.68 & 0.91 & 0.80 \\
\hline 5 & Calcium Chloride & 1.15 & 1.11 & 0.96 & 1.07 \\
\hline 6 & Untreated 3 & 2.34 & 2.88 & 1.97 & 2.40 \\
\hline 7 & Tech Suppress & 0.48 & 0.46 & 0.42 & 0.45 \\
\hline 8 & Untreated 4 & 0.25 & 0.23 & 0.41 & 0.30 \\
\hline 9 & Dust Fyghter & 0.43 & 0.48 & 0.77 & 0.56 \\
\hline
\end{tabular}


APPENDIX H PM PMIS $_{10}$ EMIONS ESTIMATES FROM EPA AP-42 EQUATION 
Table H.1 Day-8 PM ${ }_{10}$ Emissions Estimates

\begin{tabular}{|c|c|c|c|c|c|}
\hline \multirow{2}{*}{$\begin{array}{c}\text { Section } \\
\text { No. }\end{array}$} & \multirow{2}{*}{ Product Name } & \multicolumn{4}{|c|}{ PM10 Emissions Estimate (lb/VMT) } \\
\cline { 3 - 6 } & & 1 & 2 & 3 & Average \\
\hline 1 & PetroTac & 0.05 & 0.12 & 0.02 & 0.06 \\
\hline 2 & Untreated 1 & 0.68 & 0.44 & 1.13 & 0.75 \\
\hline 3 & EK 35 & 0.22 & 0.24 & 0.23 & 0.23 \\
\hline 4 & Untreated 2 & 0.65 & 0.56 & 0.84 & 0.68 \\
\hline 5 & Calcium & 0.31 & 0.29 & 0.11 & 0.24 \\
\hline 6 & Chloride & & & & \\
\hline 7 & Untreated 3 & 0.85 & 0.82 & 0.64 & 0.77 \\
\hline 8 & Tech Suppress & 0.07 & 0.06 & 0.10 & 0.08 \\
\hline 9 & Untreated 4 & 1.12 & 1.27 & 0.99 & 1.13 \\
\hline
\end{tabular}

Table H.2 Day-28 PM PM $_{10}$ Emissions Estimates

\begin{tabular}{|c|c|c|c|c|c|}
\hline \multirow{2}{*}{$\begin{array}{c}\text { Section } \\
\text { No. }\end{array}$} & \multirow{2}{*}{ Product Name } & \multicolumn{4}{|c|}{ PM10 Emissions Estimate (lb/VMT) } \\
\cline { 3 - 6 } & & 1 & 2 & 3 & Average \\
\hline 1 & PetroTac & 0.10 & 0.09 & 0.20 & 0.13 \\
\hline 2 & Untreated 1 & 0.80 & 1.01 & 0.83 & 0.88 \\
\hline 3 & EK 35 & 0.96 & 0.92 & 0.91 & 0.93 \\
\hline 4 & Untreated 2 & 0.96 & 0.88 & 0.94 & 0.93 \\
\hline 5 & Calcium & 0.52 & 0.45 & 0.67 & 0.55 \\
\hline 6 & Chloride & & & & \\
\hline 7 & Untreated 3 & 1.31 & 1.19 & 1.23 & 1.24 \\
\hline 8 & Tech Suppress & 0.36 & 0.46 & 0.46 & 0.43 \\
\hline 9 & Untreated 4 & 1.45 & 0.81 & 1.38 & 1.21 \\
\hline
\end{tabular}


Table H.3 Day-61 PM PM $_{10}$ Emissions Estimates

\begin{tabular}{|c|c|c|c|c|c|}
\hline \multirow{2}{*}{$\begin{array}{c}\text { Section } \\
\text { No. }\end{array}$} & Product Name & \multicolumn{4}{|c|}{ PM10 Emissions Estimate (lb/VMT) } \\
\cline { 3 - 6 } & & 1 & 2 & 3 & Average \\
\hline 1 & PetroTac & 0.36 & 0.21 & 0.19 & 0.25 \\
\hline 2 & Untreated 1 & 1.61 & 1.83 & 1.88 & 1.77 \\
\hline 3 & EK 35 & 1.48 & 1.32 & 1.58 & 1.46 \\
\hline 4 & Untreated 2 & 1.97 & 1.76 & 1.98 & 1.90 \\
\hline 5 & Calcium & 1.27 & 1.09 & 1.38 & 1.25 \\
\hline 6 & Chloride & & & & \\
\hline 7 & Untreated 3 & 1.63 & 2.05 & 2.44 & 2.04 \\
\hline 8 & Tech Suppress & 1.92 & 1.53 & 1.81 & 1.76 \\
\hline 9 & Untreated 4 & 2.11 & 1.94 & 2.20 & 2.09 \\
\hline
\end{tabular}

Table F.4 Day-103 PM PM $_{10}$ Emissions Estimates

\begin{tabular}{|c|c|c|c|c|c|}
\hline \multirow{2}{*}{$\begin{array}{c}\text { Section } \\
\text { No. }\end{array}$} & Product Name & \multicolumn{4}{|c|}{ PM10 Emissions Estimate (lb/VMT) } \\
\cline { 3 - 6 } & & 1 & 2 & 3 & Average \\
\hline 1 & PetroTac & 0.48 & 0.55 & 0.68 & 0.57 \\
\hline 2 & Untreated 1 & 0.56 & 0.30 & 0.33 & 0.40 \\
\hline 3 & EK 35 & 0.79 & 0.76 & 0.82 & 0.79 \\
\hline 4 & Untreated 2 & 0.54 & 0.72 & 1.00 & 0.75 \\
\hline 5 & Calcium & 0.75 & 0.75 & 0.61 & 0.70 \\
\hline 6 & Chloride & & & & \\
\hline 7 & Untreated 3 & 0.60 & 0.54 & 0.60 & 0.58 \\
\hline 8 & Tech Suppress & 0.70 & 0.67 & 0.58 & 0.65 \\
\hline 9 & Untreated 4 & 1.73 & 1.61 & 1.54 & 1.63 \\
\hline
\end{tabular}

John $\mathrm{H}$. 